\title{
ROLE OF MANGANESE REDUCTION/OXIDATION (REDOX) ON FOAMING AND MELT RATE IN HIGH LEVEL WASTE (HLW) MELTERS (U)
}

C.M. Jantzen and M.E. Stone

Publication Date: March 2007

Process Science \& Engineering Section Savannah River National Laboratory Aiken, SC 29808

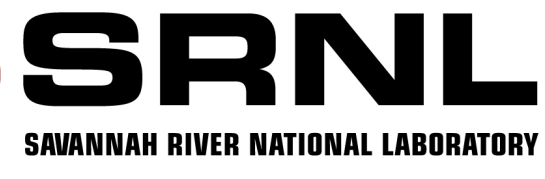




\section{DISCLAIMER}

This report was prepared by Washington Savannah River Company (WSRC) for the United States Department of Energy under Contract No. DE-AC09-96SR18500 and is an account of work performed under that contract. Neither the United States Department of Energy, nor WSRC, nor any of their employees makes any warranty, expressed or implied, or assumes any legal liability or responsibility for the accuracy, completeness, or usefulness, of any information, apparatus, or product or process disclosed herein or represents that its use will not infringe privately owned rights. Reference herein to any specific commercial product, process, or service by trademark, name, manufacturer or otherwise does not necessarily constitute or imply endorsement, recommendation, or favoring of same by WSRC or by the United States Government or any agency thereof. The views and opinions of the authors expressed herein do not necessarily state or reflect those of the United States Government or any agency thereof.

\section{Printed in the United States of America}

Prepared For

U.S. Department of Energy 
Keywords: DWPF, foaming, reboil, oxidation, reduction, melt rate

Retention: Permanent

\section{ROLE OF MANGANESE REDUCTION/OXIDATION (REDOX) ON FOAMING AND MELT RATE IN HIGH LEVEL WASTE (HLW) MELTERS (U)}

C.M. Jantzen and M.E. Stone

Publication Date: March 2007 


\section{REVIEWS AND APPROVALS}

\section{AUTHORS:}

Carol M. Jantzen, Process Science \& Engineering

Date

Michael E. Stone, Process Science \& Engineering

Date

\section{TECHNICAL REVIEWERS:}

Alexander S. Choi, Process Science \& Engineering

Date

Michael E. Smith, Process Science \& Engineering

Date

\section{APPROVERS}

Richard E. Edwards, Manager, Process Science \& Engineering

Date

David A. Crowley, Manager, Stabilization Science Research

Date

Connie C. Herman, Manager, Process Engineering Technology

Date

John E. Occhipinti, Manager, Process Cognizant Engineering-Waste

Date

Solidification Engineering 


\section{EXECUTIVE SUMMARY}

High-level nuclear waste is being immobilized at the Savannah River Site (SRS) by vitrification into borosilicate glass at the Defense Waste Processing Facility (DWPF). Control of the REDuction/OXidation (REDOX) equilibrium in the DWPF melter is critical for processing high level liquid wastes. Foaming, cold cap roll-overs, and off-gas surges all have an impact on pouring and melt rate during processing of high-level waste (HLW) glass. All of these phenomena can impact waste throughput and attainment in Joule heated melters such as the DWPF. These phenomena are caused by gas-glass disequilibrium when components in the melter feeds convert to glass and liberate gases such as $\mathrm{H}_{2} \mathrm{O}$ vapor (steam), $\mathrm{CO}_{2}, \mathrm{O}_{2}, \mathrm{H}_{2}, \mathrm{NO}_{\mathrm{x}}$, and/or $\mathrm{N}_{2}$.

During the feed-to-glass conversion in the DWPF melter, multiple types of reactions occur in the cold cap and in the melt pool that release gaseous products. The various gaseous products can cause foaming at the melt pool surface. Foaming should be avoided as much as possible because an insulative layer of foam on the melt surface retards heat transfer to the cold cap and results in low melt rates. Uncontrolled foaming can also result in a blockage of critical melter or melter off-gas components. Foaming can also increase the potential for melter pressure surges, which would then make it difficult to maintain a constant pressure differential between the DWPF melter and the pour spout. Pressure surges can cause erratic pour streams and possible pluggage of the bellows as well.

For these reasons, the DWPF uses a REDuction/OXidation (REDOX) strategy and controls the melt REDOX between $0.09 \leq \mathrm{Fe}^{2+} / \Sigma \mathrm{Fe} \leq 0.33$. Controlling the DWPF melter at an equilibrium of $\mathrm{Fe}^{+2} / \Sigma \mathrm{Fe} \leq 0.33$ prevents metallic and sulfide rich species from forming nodules that can accumulate on the floor of the melter. Control of foaming, due to deoxygenation of manganic species, is achieved by converting oxidized $\mathrm{MnO}_{2}$ or $\mathrm{Mn}_{2} \mathrm{O}_{3}$ species to $\mathrm{MnO}$ during melter preprocessing. At the lower redox limit of $\mathrm{Fe}^{+2} / \Sigma \mathrm{Fe} \sim 0.09$ about $99 \%$ of the $\mathrm{Mn}^{+4} / \mathrm{Mn}^{+3}$ is converted to $\mathrm{Mn}^{+2}$. Therefore, the lower REDOX limit eliminates melter foaming from deoxygenation.

Organic, nitrate, and manganese concentrations in the DWPF melter feed are the major parameters influencing melt REDOX. Organics such as formates, coal, and oxalate act as reductants, while nitrates, nitrites, and manganic $\left(\mathrm{Mn}^{+4}\right.$ and $\left.\mathrm{Mn}^{+3}\right)$ species act as oxidants.

A REDOX model was developed for DWPF melt processing that relates the $\mathrm{Fe}^{+2} / \Sigma \mathrm{Fe}$ ratio of the final glass to the molar concentrations of the oxidants and reductants in the melter preprocessing vessels, either the Sludge Receipt and Adjustment Tank (SRAT) or the Slurry Mix Evaporator (SME). The DWPF REDOX model is based on Electron Equivalents (EE) that are exchanged during chemical reduction (making an atom or molecule less positive by electron transfer) and oxidation (making an atom or molecule more positive by electron transfer). Therefore, the number of electrons transferred for each REDOX reaction can be summed and an Electron Equivalents term for each organic and oxidant species defined: 


$\begin{array}{llll}- & {\left[\mathrm{NO}_{3}\right]} & = & +5 \\ - & {[\mathrm{Mn}]} & = & +2 \\ - & {[\mathrm{C}]_{\text {formate }}} & = & -2 \\ - & {[\mathrm{C}]_{\text {coal }}} & = & -4 \\ - & {[\mathrm{C}]_{\text {oxalate }}} & = & -4 \\ - & {[\mathrm{C}]_{\text {sugar }}} & = & -4\end{array}$

The overall relationship between the REDOX ratio and the Electron Equivalents, $\xi$, was, therefore, expressed as the following in 2003:

$$
\begin{aligned}
& \mathrm{Fe}^{+2} / \Sigma \mathrm{Fe}=0.1942+0.1910 *\left(2[F]+4[C]+4\left[\mathrm{O}_{\mathrm{T}}\right]-5[N]-2[M n]\right) \frac{45}{T} \\
& \text { where }[\mathrm{F}]=\text { formate }(\mathrm{mol} / \mathrm{kg} \text { feed }) \\
& {[\mathrm{C}]=\text { coal }(\text { carbon })(\mathrm{mol} / \mathrm{kg} \text { feed })} \\
& {\left[\mathrm{O}_{\mathrm{T}}\right]=\text { oxalate }_{\text {Total }}(\text { soluble and insoluble })(\mathrm{mol} / \mathrm{kg} \text { feed })} \\
& {[\mathrm{N}]=\text { nitrate }+ \text { nitrite }(\mathrm{mol} / \mathrm{kg} \text { feed })} \\
& {[\mathrm{Mn}]=\text { manganese }(\mathrm{mol} / \mathrm{kg} \text { feed })} \\
& \mathrm{T}=\text { total solids }(\mathrm{wt} \%)
\end{aligned}
$$

Higher manganese concentrations had been experienced in the early projections of DWPF Sludge Batch 4 (SB4) compositions than during the 2003 processing of Sludge Batch 3. During non-radioactive melt rate testing of SB4 feed simulants, the $2003 \mathrm{EE}$ model predicted a REDOX target of $\mathrm{Fe}^{2+} / \Sigma \mathrm{Fe}$ of 0.2 but produced glasses that were overly oxidized, $\mathrm{Fe}^{2+} / \Sigma \mathrm{Fe} \sim 0$. These overly oxidized feeds foamed and the copious amounts of foam adversely impacted melt rate. At this point the EE model parameters were reinvestigated and it was determined the high nitrate in DWPF SB4 feeds was reoxidizing divalent manganese in the melter feeds during the denitration reactions in the cold cap. This process appears to be happening once but may be occurring multiple times in the cold cap reactions. Therefore, the manganese in the cold cap is likely manganese +7 and not $\mathrm{Mn}^{+4}$ as previously assumed.

Therefore, the 2003 DWPF EE REDOX model was refit with a factor of 5 for the manganese EE transfer in order to avoid foaming in high manganese containing feeds:

$$
\frac{F e^{2+}}{\Sigma F e}=f\left[\left(2[F]+4[C]+4\left[\mathrm{O}_{\mathrm{T}}\right]-5[N]-5[M n]\right) \frac{45}{T}\right]=f[\xi]
$$

where

$$
\begin{array}{lll}
f & = & \text { indicates a function } \\
{[\mathrm{F}]} & = & \text { formate }(\mathrm{mol} / \mathrm{kg} \text { feed }) \\
{[\mathrm{C}]} & = & \text { coal }(\text { carbon })(\mathrm{mol} / \mathrm{kg} \text { feed }) \\
{\left[\mathrm{O}_{\mathrm{T}}\right]} & = & \text { oxalate } \\
\text { Total } & \text { (soluble and insoluble) }(\mathrm{mol} / \mathrm{kg} \text { feed }) \\
{[\mathrm{N}]} & = & \text { nitrate }+ \text { nitrite }(\mathrm{mol} / \mathrm{kg} \text { feed }) \\
{[\mathrm{Mn}]} & = & \text { manganese }(\mathrm{mol} / \mathrm{kg} \text { feed }) \\
\mathrm{T} & = & \text { total solids }(\mathrm{wt} \%)
\end{array}
$$




$$
\xi=\left(2[F]+4[C]+4\left[\mathrm{O}_{\mathrm{T}}\right]-5[N]-5[M n]\right) \frac{45}{T}
$$

and

$$
\frac{F e^{+2}}{\sum F e}=0.2358+0.1999 \xi
$$

The $\frac{\mathrm{Fe}^{2+}}{\Sigma F e}$ predictions from the Electron Equivalents model given above were fitted to measured REDOX data generated from the DWPF melter from SME Batch 224, to data generated by the SRTC mini-melter, and to data from the SRTC Slurry-fed Melt Rate Furnace (SMRF). Since only 19 data points were available for the development of the revised manganese term and many of the glasses were inhomogeneous due to the high viscosity of the feeds, the five EE transfer for manganese should be further verified for higher manganese containing feeds. 


\section{TABLE OF CONTENTS}

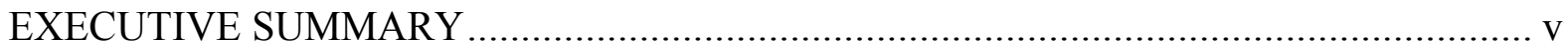

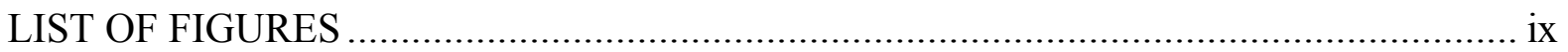

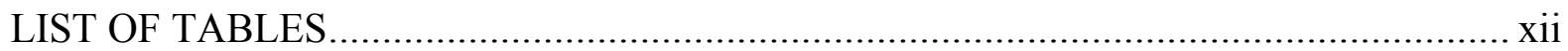

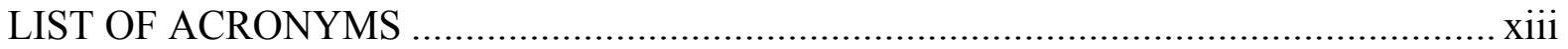

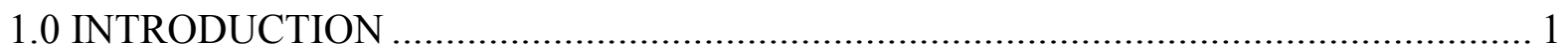

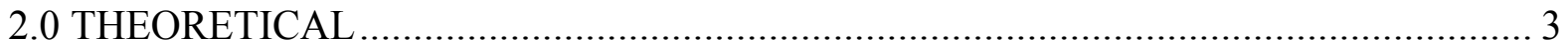

2.1 Foam vs. Reboil ................................................................................. 3

2.2 DWPF Melter Feed Preprocessing for Foam Minimization............................... 5

2.3 DWPF REDOX Control Limits for Foam Minimization ................................... 6

2.4 DWPF REDOX Model for Foam Minimization........................................... 11

2.5 Gas-Glass Disequilibrium in Production Melters ......................................... 18

3.0 HISTORICAL MELTER EXPERIENCES WITH FOAMING ................................. 19

3.1 Savannah River Site .......................................................................... 19

3.2 Pacific Northwest National Laboratory .................................................... 20

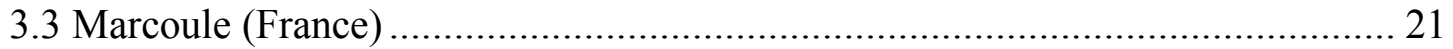

3.4 Analyses of Gases in Foam from Pilot and Production Melters ......................... 23

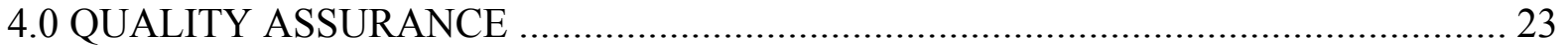

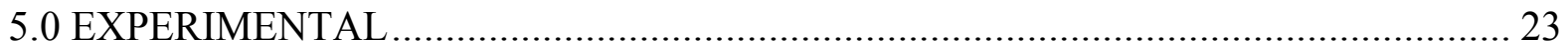

6.0 RESULTS AND DISCUSSION ...................................................................... 26

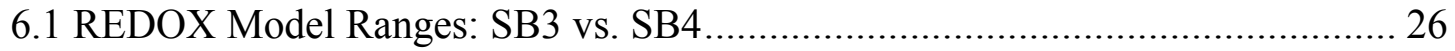

6.2 Glass Composition Ranges: SB3 vs. SB4 ................................................. 30

6.3 Role of Glass Homogeneity and Variability in REDOX Measurements and Modeling Database.................................................................................... 32

6.4 REDOX Modeling................................................................................. 44

6.5 Origin of $\mathrm{Mn}^{+7}$ Reactions During Melter Feed to Glass Conversion: SRAT

Product or Cold Cap Molten Salt? ............................................................... 49

6.5.1 Identification of a Molten Salt Phase at $\leq 300^{\circ} \mathrm{C}$.............................. 50

6.5.2 Stabilization of $\mathrm{Mn}^{+7}$ by a Molten Salt Phase in the Cold Cap ............. 56

6.5.3 Verification of Oxidized Manganese Species by SB4 Soluble

Supernate Components ............................................................. 57

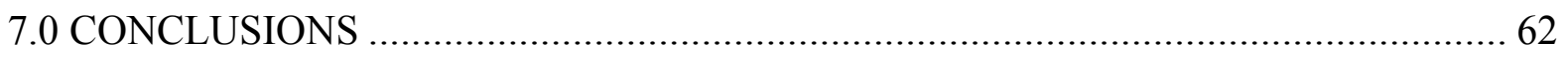

8.0 RECOMMENDATIONS/PATH FORWARD ........................................................ 62

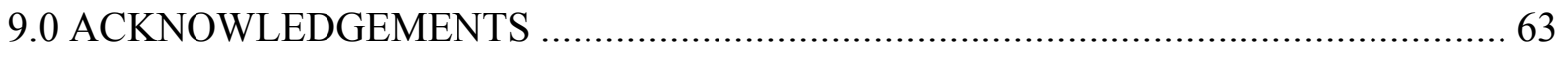

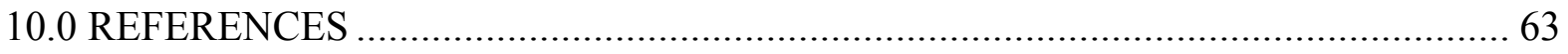




\section{LIST OF FIGURES}

Figure 1. Relationship among dissolved water, total oxidized REDOX species (representing oxygen dissolved in the melt) and reboil pressure measured on highly oxidized glasses collected from a liquid-fed ceramic melter as a function of run time (from Goldman, 21) ...................................................... 5

Figure 2. Electromotive Force (EMF) series developed for DWPF glass at $1150^{\circ} \mathrm{C}[22] \ldots . .7$

Figure 3. Comparison of stability relations among the oxides of iron and manganese as a function of temperature and oxygen partial pressure [40] ........................... 10

Figure 4. Four stage DWPF cold cap model from Choi $[42,44,45]$.

Figure 5. Measured REDOX data from pilot scale melters, crucible studies, SMRF studies and the DWPF Production melter. The calculations were performed based on the SME composition results adjusted to $45 \mathrm{wt} \%$ solids.

Figure 6. Concentrations of nitrate (molar) and formate (molar) processed in SGM, IDMS, and DWPF. The formate and nitrate concentrations that are acceptable to avoid foaming, e.g. $\mathrm{Fe}^{+2} / \sum \mathrm{Fe}$ values between 0.09 and 0.33 , are shaded for emphasis. These limits correspond to the limits defined by the Schreiber EMF series. Note that some melter campaigns between the $\mathrm{Fe}^{+2} / \Sigma \mathrm{Fe}$ limit of 0.09 and the analytic detection limit of 0.03 also did not report foaming events. However, use of the REDOX ratio at the detection limit for process control is not advisable and the limit of $\mathrm{Fe}^{+2} / \Sigma \mathrm{Fe}=0.09$ is conservative. Solid squares represent IDMS campaigns and X represents Scale Glass Melter (SGM) campaigns.

Figure 7. Comparison of target waste loading and Mn concentration on a slurry basis in the Sludge Receipt Adjustment Tank (SRAT) products tested during REDOX modeling. The "+" values (red) indicate SB3 REDOX data, the solid circles (blue) indicate SB4 REDOX data, and the " $\mathrm{x}$ " values (green) indicate HISTORIC REDOX model data (if available) from crucibles.

Figure 8. Comparison of the Mn SRAT concentration on a dry calcine oxide basis and in the SME products tested during REDOX modeling. The "+" values (red) indicate SB3 REDOX data, the solid circles (blue) indicate SB4 REDOX data, and the " $x$ " values (green) indicate HISTORIC REDOX model data (if available) from crucibles.

Figure 9. Manganese in final glass product for SB3 vs. SB4. The "+" values (red) indicate SB3 REDOX data, the solid circles (blue) indicate SB4 REDOX data, 
and the " $x$ " values (green) indicate HISTORIC REDOX model data (if available) from crucibles.

Figure 10. Soluble manganese in SB4 vs. SB3 SRAT supernates.

Figure 11. The relation of soluble manganese to stoichiometric acid concentrations and $\mathrm{pH}$ in the SRAT for SB3 (+) and SB4 (•)

Figure 12. Comparison of the formate and nitrate in the SME products tested during REDOX modeling. The "+" values (red) indicate SB3 REDOX data, the solid circles (blue) indicate SB4 REDOX data, and the " $x$ " values (green) indicate HISTORIC REDOX model data (if available) from crucibles.

Figure 13. Comparison of alumina and iron oxides in SB3 vs. SB4 glasses used for REDOX testing. The "+" values (red) indicate SB3 REDOX data and the solid circles (blue) indicate SB4 REDOX data. HISTORIC REDOX model data was not available.

Figure 14. Comparison of total alkali (frit and sludge $\mathrm{Na}_{2} \mathrm{O}, \mathrm{Li}_{2} \mathrm{O}$, and $\mathrm{K}_{2} \mathrm{O}$ ) and boron oxides in the glasses used for REDOX testing. Since the $\mathrm{B}_{2} \mathrm{O}_{3}$ comes from the frit only, the frit designations are given on the figure. The "+" values (red) indicate SB3 REDOX data and the solid circles (blue) indicate SB4 REDOX data. HISTORIC REDOX model data was not available.

Figure 15. Relation of manganese and iron oxide in the glasses REDOX tested in SB3 $(+)$ and SB4 $(\bullet)$ to the measured REDOX ratio.

Figure 16. Inhomogeneities in SB4 glasses made with formic acid and nitric acid additions only.

Figure 17. Homogeneous SB2/3 glass made with formic acid and nitric acid additions only. 35

Figure 18. SB4 inhomogeneities and metallic species caused by excess alternate reductant.

Figure 19. The SB4 REDOX data overlain on Equation 9, the 2003 DWPF EE REDOX Model [15] indicating the oxidized bias in the SB4 data to the 2003 REDOX model. The solid line represents the 2003 DWPF EE REDOX Model $\left(\mathrm{Fe}^{+2} / \Sigma \mathrm{Fe}=0.1942 \xi+0.191\right)$ and the dashed lines represent the Upper and Lower $95 \%$ confidence limits so the slope of the line is 1.00 and the intercept is zero. The gray solid circles are the data used in the generation and validation of the 2003 DWPF EE REDOX model and plot. The stars are the SB4 crucible data that are superimposed for comparison.

Figure 20. Validation of the Equation 9 terms for alternate reductants using various assumptions for the electron equivalents transfer of manganese. The solid 
lines represents the 2003 DWPF EE REDOX Model $\left(\mathrm{Fe}^{+2} / \Sigma \mathrm{Fe}=0.1942 \xi+\right.$ 0.191 ) and the dashed lines represent the Upper and Lower 95\% confidence limits. The slope of the regression in the upper figure is 1.00 and the intercept is zero, the slope of the regression in the lower figure is 1.00 and the intercept is 0.05

Figure 21. Fit of the SB4 REDOX data to Equation 9 using a five electron transfer for manganese instead of a two electron transfer. The solid lines represents the 2003 DWPF EE REDOX Model $\left(\mathrm{Fe}^{+2} / \Sigma \mathrm{Fe}=0.1942 \xi+0.191\right)$ and the dashed lines represent the Upper and Lower 95\% confidence limits. The slope of the line is 1.00 and the intercept is 0.05 . The gray solid circles are the data used in the generation and validation of the 2003 DWPF EE REDOX model and plot. The stars are the SB4 crucible data.

Figure 22. Fit of Equation 10 to the pooled historic, SB3 and SB4 REDOX data

Figure 23. X-ray diffraction spectra of SB4-32 during the sludge to glass conversion between $300-500^{\circ} \mathrm{C}$ and SB4-32 conversion at $300^{\circ} \mathrm{C}$ in the absence of frit...... 54

Figure 24. Comparison of SB4-32 melter feed at $300^{\circ} \mathrm{C}$ to conversion of SB2/3 melter feed at $350^{\circ} \mathrm{C}$. Bragg reflections belonging to a mixed alkali nitrate-nitrite phase appear only in SB4 feeds.

Figure 25. Phase equilibria of a mixed molten salt phase. 56

Figure 26. Reference glasses made with $\mathrm{Mn}^{+2}, \mathrm{Mn}^{+4}$ and $\mathrm{Mn}^{+7}$ solutions. ....................... 58

Figure 27. Test glasses made with varying amounts of nitrate and formate and $\mathrm{Mn}^{+2} \mathrm{Cl}_{2} \ldots 59$

Figure 28. Test glasses made with varying amounts of nitrate and formate and $\mathrm{Mn}^{+2} \mathrm{Cl}_{2} \ldots 59$

Figure 29. Relative concentrations of the manganese, formate and nitrate in the frit experiments compared to historic, SB3 and SB4 testing. 60

Figure 30. SB4 SRAT supernates tested in sealed crucibles with Frit 418. 61

Figure 31. Solving Equation 11 at the minimum REDOX modeled, e.g. $\mathrm{Fe}^{+2} / \Sigma \mathrm{Fe}=0.03$, for the frit experiments. Gray crossed indicate glasses in Figure 27 that are clear and indicative of $\mathrm{Mn}^{+2}$ while purple solid circles indicate glasses that were purple in color indicative of $\mathrm{Mn}^{+3}$. 


\section{LIST OF TABLES}

Table 1. Reference Composition of Waste Types by Element (Wt\% Washed, Dried Insoluble Solids) From Reference 18

Table 2. Maximum Theoretical Moles of Oxygen Released when Multi-Valent Species Entering a Melter are Reduced.

Table 3 History of the Scale Glass Melter (SGM) and the Integrated DWPF Melter System (IDMS)

Table 4. Sludge Batch 4 Feeds Tested for REDOX …............................................... 25

Table 5. REDOX Model Data (Historic, SB3 and SB4)............................................ 37

Table 6. Summary of Phases Formed During SB4 Feed to Glass Conversion in Sealed Crucibles.

Table 7. Comparison of the d-spacings of Unidentified Phases in SB4-32 with Various Nitrate and Nitrite Compounds. 


\section{LIST OF ACRONYMS}

\begin{tabular}{|l|l|}
\hline CPC & Chemical Process Cell \\
\hline DOE & Department of Energy \\
\hline DSC & Differential Scanning Calorimetry \\
\hline DWPF & Defense Waste Processing Facility \\
\hline EE & Electron Equivalents \\
\hline EMF & Electromotive Force \\
\hline FA & Formic Acid \\
\hline LHW & Low Heat Waste \\
\hline LSFM & Large Slurry Fed Melter \\
\hline HAN & Hydroxylamine nitrate \\
\hline HHW & High Heat Waste \\
\hline HLW & High Level Waste \\
\hline IDMS & Integrated DWPF Melter System \\
\hline MM & Minimelter \\
\hline MRF & Melt Rate Furnace \\
\hline OLS & Ordinary Least Squares \\
\hline PHA & Precipitate Hydrolysis Aqueous \\
\hline PNNL & Pacific Northwest National Laboratory \\
\hline PSAL & Process Science Analytical Laboratory \\
\hline REDOX & REDuction/OXidation \\
\hline RMSE & Root Mean Square Error \\
\hline SB & Sludge Batch \\
\hline SCM & Small Cylindrical Melter \\
\hline SEM & Scanning Electron Microscopy \\
\hline SGM & Scale Glass Melter \\
\hline SME & Slurry Mix Evaporator \\
\hline SMRF & Slurry-fed Melt Rate Furnace \\
\hline SRAT & Sludge Receipt and Adjustment Tank \\
\hline SRS & Savannah River Site \\
\hline SRNL & Savannah River National Laboratory \\
\hline TPB & Tetraphenylborate \\
\hline TTR & Technical Task Request \\
\hline TT\&QAP & Technical Task and Quality Assurance Plan \\
\hline WSRC & Washington Savannah River Company \\
\hline WVFS & West Valley Fuel Services \\
\hline XRD & X-Ray Diffraction \\
\hline & \\
\hline
\end{tabular}




\subsection{INTRODUCTION}

Foaming, cold cap roll-overs, and off-gas surges all have an impact on pouring and melt rate during processing of high-level waste (HLW) glass. All of these phenomena can impact waste throughput and attainment in Joule heated melters such as the Defense Waste Processing Facility (DWPF). These phenomena are caused by gas-glass disequilibrium when components in the melter feeds convert to glass and liberate gases such as $\mathrm{H}_{2} \mathrm{O}$ vapor (steam), $\mathrm{CO}_{2}, \mathrm{O}_{2}, \mathrm{H}_{2}, \mathrm{NO}_{\mathrm{x}}$, and/or $\mathrm{N}_{2}$. During the feed-to-glass conversion in the DWPF melter, multiple types of reactions occur in the cold cap and in the melt pool that release gaseous products. The various gaseous products can cause foaming at the melt pool surface $[1,2,3,4,5,6]$. Foaming should be avoided as much as possible because an insulative layer of foam on the melt surface retards heat transfer to the cold cap and results in low melt rates. Uncontrolled foaming can also result in a blockage of critical melter or melter off-gas components [7]. Foaming can also increase the potential for melter pressure surges which would then make it difficult to maintain a constant pressure differential between the DWPF melter and the pour spout. Pressure surges can cause erratic pour streams and possible pluggage of the bellows as well.

Experience in the commercial glass industry, as well as experience in HLW processing in pilot scale melters at the Savannah River Site (SRS) [1,3], Pacific Northwest National Laboratory (PNNL), and Marcoule France, have indicated that bubble formation in the form of foam or reboil ${ }^{\ddagger}$ can impact melter performance in different ways (see Section 3.0). Foam can be $\mathrm{CO}_{2}$ rich, $\mathrm{O}_{2}$ rich, $\mathrm{N}_{2}$ rich, $\mathrm{H}_{2} \mathrm{O}$ vapor rich, or combinations of these gases (see Section 3.4). In French waste glass melters, nitrate rich foams were mitigated by precalcining the high nitrate wastes prior to introduction of the HLW feed into a glass melter (see Section 3.3).

In the commercial glass industry and in HLW waste glass melters, bubble formation as foam can impact melt rate and attainment, while bubble formation as reboil can impact pouring [8]. In addition, gas evolution in the form of bubbles can greatly enhance refractory corrosion by rapidly replacing refractory-saturated glass with fresh material [1]. It is well documented that changes in melt velocity from any cause can accelerate refractory corrosion, e.g. increases from static conditions to 1.1 inches per second caused a 2.5 fold increase in Monofrax K-3 corrosion in 3 days [9]. Bubble formation in the form of foam or reboil should, therefore, be minimized because of the impacts on melt rate, pouring, and refractory corrosion. For this reason, the DWPF has always processed radioactive HLW using a REDuction/OXidation (REDOX) strategy that is designed to minimize gas-generation in the form of foam and/or reboil.

Off-gas surges were experienced in the DWPF HLW production melter during processing of DWPF Sludge Batch 1 (SB1) when nitric acid rich feeds were being processed, i.e. an overly oxidized flowsheet [10] based on balancing one mole of nitrate against one mole of formate in the feed was being followed. The surges were studied by neural net modeling of thirty-nine DWPF melter parameters. This modeling indicated that melter feed flow and melter level (which includes any contributions from foam generation) had a direct impact on the melter pour surges [11].

reboil is the appearance of bubbles in glass after it appears to be bubble-free (I.J. McColm, "Dictionary of Ceramic Science and Engineering," $2^{\text {nd }}$ Edition, Plenum Press, New York, 1994). 
Offgas surges were more noticeable during processing of DWPF Sludge Batch 2 (SB2) even after the implementation of a more reducing REDOX correlation [12] that balanced one mole of nitrate against three moles of formate in the feed. DWPF SB2 contained higher noble metal content than SB1 feeds [13] and it is known that higher noble metal content can catalyze formic acid decomposition [14] and liberate excess gases especially $\mathrm{H}_{2}$ during feed preparation and during cold cap reactions.

DWPF Sludge Batch 3 (SB3) was purported to contain high concentrations of reductants that were not in the simple formate vs. nitrate REDOX correlations used for SB1 and SB2: species such as oxalate and coal. An Electron Equivalents (EE) REDOX model was developed with terms for the additional reductants $[15,16]$. In addition, a manganese term was added to the EE model to account for potential differences in the oxidation state of $\mathrm{Mn}$ in the feed $(+4)$ and in the glass (+2). When coal and oxalate were absent, the EE model reverted to an $[\mathrm{F}]-2.5[\mathrm{~N}]$ stoichiometry plus the term for manganese. At the time the EE model was developed, further investigation into the role of oxidized Mn species $(+4,+5,+6$, and +7$)$ and oxidized $U$ species $(+6)$ in the feed that could cause the formation of oxygen rich foams was suggested. However, the EE REDOX correlation performed well during DWPF SB3 radioactive waste processing and these experiments were postponed.

During non-radioactive melt rate testing of Sludge Batch 4 (SB4) feed simulants, the EE model predicted a REDOX target of $\mathrm{Fe}^{2+} / \Sigma \mathrm{Fe}$ of 0.2 but produced glasses that were overly oxidized, $\mathrm{Fe}^{2+} / \Sigma \mathrm{Fe} \sim 0$. These overly oxidized feeds foamed and the copious amounts of foam adversely impacted melt rate [17]. At this point the EE model parameters were reinvestigated considering the following questions:

- Are the SB4 feeds out of the bounds over which the EE model had been developed and validated?

- Although not components of SB4, are the EE parameters for the reductants coal, oxalate, and sugar correct since they may be necessary to mitigate the overly oxidizing conditions?

- Are the EE parameters for the oxidizer manganese correct?

Further investigation of the EE model parameters, especially the manganese term, is the focus of the current study. The role of Mn is especially important because SB4 contains HM waste from Tank 11 and HM HHW is simultaneously high in Al and Mn (Tank 11 is considered HM $\mathrm{HHW}^{f}$ ). Both HM low heat waste (LHW) and Purex high heat waste (HHW) are even higher in Mn compared to $\mathrm{Al}$ and compared to $[\mathrm{Al}+\mathrm{Fe}$ (Table 1). Thus, SB4 was initially anticipated to be higher in Mn than SB1-SB3 depending on how much Tank 11 waste was added to SB4. Moreover, future sludge batches made with HM LHW and Purex HHW [18] will continue to have a high Mn content. These differences in the Mn concentration come about from the following:

\footnotetext{
${ }^{f}$ e-mail on 01/03/07 from Jeffrey Gillam to C.M. Jantzen
} 
- The HM wastes were generated from higher activity uranium $\left(\mathrm{U}^{235}\right)$-aluminum alloy fuel than the Purex wastes which were generated with $\mathrm{U}^{238}$.

- A manganese dioxide precipitation strike was used in the head end of both processes to remove fission products like $\mathrm{Zr}$ and $\mathrm{Nb}$ by sorption if the beta/gamma activity of the wastes were above certain limits.

- Even more Mn was used when the activity was higher and this coincided with processing of the HHW (Purex and HM).

- The HM fuel was also clad in aluminum and during waste generation the entire assembly was dissolved in nitric acid without a separate aluminum decladding step as done in Purex processing [19], therefore the HM HHW is diluted by large concentrations of $\mathrm{Al}$ in the sludge compared to the HM LHW and the Purex HHW.

Table 1. Reference Composition of Waste Types by Element (Wt\% Washed, Dried Insoluble Solids) From Reference 18

\begin{tabular}{|c|c|c|c|c|}
\hline Species & Purex LHW & Purex HHW & HM LHW & HM HHW \\
\hline $\mathrm{Al}$ & 4.81 & 2.25 & 7.13 & 23.18 \\
\hline $\mathrm{Fe}$ & 25.08 & 25.35 & 24.04 & 5.33 \\
\hline $\mathrm{Mn}$ & 2.65 & 7.65 & 7.46 & 1.64 \\
\hline $\mathrm{Mn} /[\mathrm{Al}+\mathrm{Fe}])$ & 0.09 & 0.28 & 0.24 & 0.06 \\
\hline $\mathrm{Mn} / \mathrm{Al}$ & 0.55 & 3.4 & 1.05 & 0.07 \\
\hline
\end{tabular}

\subsection{THEORETICAL}

\subsection{Foam vs. Reboil}

Bubbles forming foam impede heat transfer into the melt causing the glass to cool and sometimes become too viscous [8]. Foaming, if it occurs, is normally problematic early in the melting of a feed batch and occurs at the melt temperature [8]. Under certain melt conditions, bubbles may grow and persist in a glass melt which is already reasonably well reacted or else bubbles formed early in the melting process may not collapse as they normally should. Such bubbles cause reboil which tends to occur at $\sim 100-300^{\circ} \mathrm{C}$ below the melt temperature well after conversion from feed to glass [8]. Reboil is a "working end" or pouring problem that can lead to unwanted bubbles in the glass product [8].

The physics of bubble formation via foaming or reboil differ in only one way: foams require some mechanism to stabilize thin liquid films (bubble walls) and prevent gasses from escaping until the bubble walls become so thin that they rupture spontaneously [8]. Otherwise, the necessary initial steps to initiate foam or reboil are the same as shown below: 
- the melt must become supersaturated with respect to some gas

- bubble formation must be nucleated

- bubble growth to a size that ruptures or persists as a glass product defect

The nucleation of foams and/or reboil bubbles can occur heterogeneously on pores and crystals in melter refractories [8], platinum or other noble metal particles in the melt [8], carbon or dust particles in the furnace atmosphere [8], and on crystallites (ferrite-spinel crystals) which form on the melt pool surface and locally increase the effective viscosity of the molten liquid in the foam $[1,3]$. Specific causes of reboil have been summarized by Lorey [20] as follows:

- Physical supersaturation of gases caused by pressure or temperature change

- Chemical supersaturation caused by poor mixing or composition differences caused by refractory dissolution, volatilization, or atmospheric changes

- Discharge of electrolytic cells set up by temperature, material, or composition gradients in the melter

- Variation in equilibrium of valence states in the melt pool

Reboil pressure and foaming tendency were positively correlated in Goldman's [21] studies of simulated waste glasses during pilot scale melting. Highly oxidized glasses (lacking ferrous iron) were determined to have the highest reboil pressures. These glasses were made from slurries containing nitrate chemicals in the absence of any reducing agents. These studies established a correlation between reboil pressures and the amount of oxygen and water dissolved in the melt (Figure 1). The experiments were supported by mass spectrometric analysis of the gases in the foam collected from the melter surface (see also Section 3.4).

In the melt pool, transition metal species such as $\mathrm{Fe}^{+3}$ and $\mathrm{Mn}^{+4}$ release $\mathrm{O}_{2}$ gas at the elevated melter temperatures $[22,23,24]$ in the absence of any oxidizing or reducing agents in the melt. This is because $\mathrm{Mn}^{+3}$ or $\mathrm{Mn}^{+2}$ is normally the stable species in a melt at elevated temperature and even higher temperatures stabilize $\mathrm{Fe}^{+2}$. Any carbon containing reducing species in the melter feeds (coal, oxalate, formic acid, sugar) can cause additional reduction of transition metal species, such as $\mathrm{Fe}^{+3}$ and $\mathrm{Mn}^{+4}$, at the elevated melter temperatures $[24,25,27]$ and additional release of $\mathrm{O}_{2}$ gas. The carbon based reductants themselves liberate $\mathrm{CO}_{2}$ as found in the foam of a formic acid only SRS pilot scale campaign [25] by mass spectrometric analysis and in SB2 simulant studies using sugar as a reductant [26]. The interaction of the carbon with the transition metal species in the waste feed occurs primarily in the melter cold cap $[27,28]$ but gas-glass disequilibrium can occur in the melt pool as discussed in Section 2.5.

Foaming and reboil can be prevented by minimizing gas release, preventing bubble formation, or destabilizing any bubbles which form [29]. Bubble formation and gas release, in turn, can be minimized by avoiding any of the four criteria outlined by Lorey [20] above as causative agents 
of reboil. In particular, gradients in temperature, glass composition, or variable valence states in a production or pilot scale melter promote bubble formation [20,30].

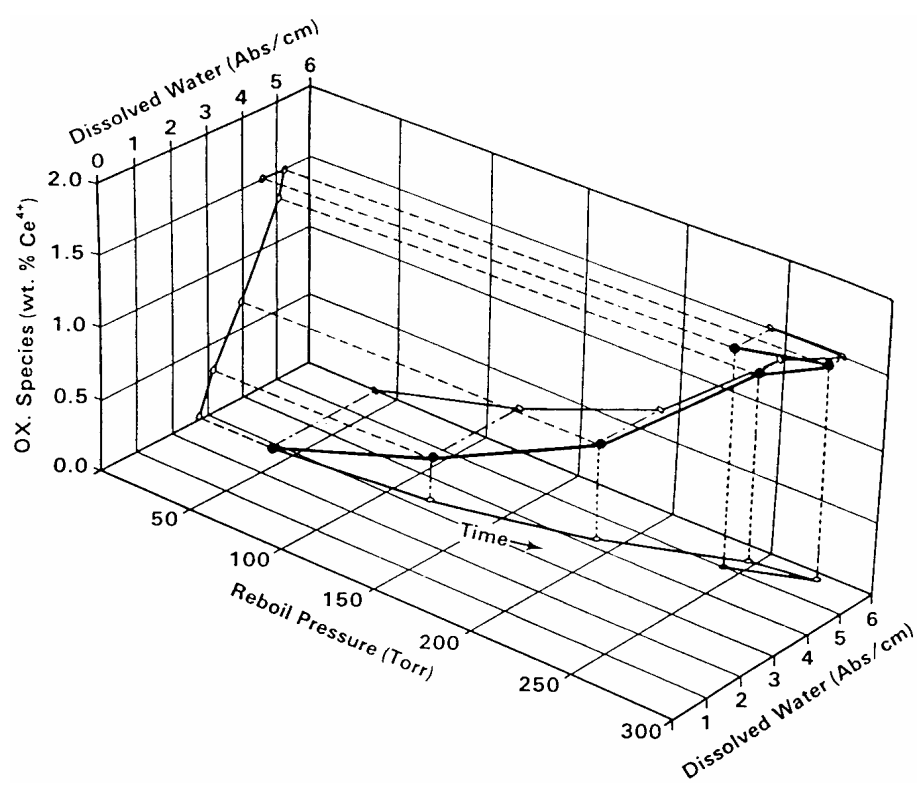

Figure 1. Relationship among dissolved water, total oxidized REDOX species (representing oxygen dissolved in the melt) and reboil pressure measured on highly oxidized glasses collected from a liquid-fed ceramic melter as a function of run time (from Goldman, 21).

\subsection{DWPF Melter Feed Preprocessing for Foam Minimization}

The high-level nuclear waste that is being immobilized at SRS by vitrification into borosilicate glass at the DWPF undergoes pretreatment in the Sludge Receipt and Adjustment Tank (SRAT). This pretreatment strategy was instituted based on the work of Hrma in the 1980's specifically for the DWPF [summarized by Plodinec in 4,5]. Hrma's experiments, which were performed in the absence of nitrates, indicated that melter foaming from oxygen liberation would not be extensive with the DWPF formic acid flow sheet if a minimum of $66 \%$ of the oxidized $\mathrm{Mn}^{+4}$ present in a waste feed were reduced to $\mathrm{Mn}^{+2}$ prior to vitrification (see discussion in Section 2.3).

To test Hrma's bench top studies, a reductant, formic acid, that was also being used to reduce mercury to the metallic state, was added to various pilot scale melter feeds in the SRAT/Slurry Mix Evaporator (SME) to convert the $\mathrm{Mn}^{+4}$ to $\mathrm{Mn}^{+2}$ prior to vitrification. The strategy proved successful and pre-reduction of oxidized $\mathrm{Mn}^{+4}$ to eliminate melter foaming due to subsequent deoxygenation in the glass melt was implemented for all subsequent DWPF flowsheet testing. Various percentages for the $\mathrm{Mn}^{+4}$ reduction in the SRAT have been suggested [4,5,14,32] ranging from 40-66\%. However, the DWPF REDOX correlation developed in 1998 [12] was 
predicated on the fact that the $\mathrm{Mn}^{+4}$ reduction in the SRAT was $\geq 66 \%$ because the model only contained terms for nitrates and formates. Since the actual percentage of Mn reduction could not always be verified for a DWPF feed, a Mn term was added to the EE REDOX model developed in 2003 [15].

In summary, the insoluble fraction of the waste sludge is refluxed with acid [31] in the SRAT for the following reasons:

- control potential foaming in the melter by decomposing oxygen and carbonate producing species in the SRAT before the feed enters the melter:

- destroy the nitrite $\left(\mathrm{NO}_{2}\right)$ in the feed

- convert all carbonates in the feed to $\mathrm{CO}_{2}$, and

- convert 40-66\% of the oxidized $\mathrm{Mn}^{+4}$ or $\mathrm{Mn}^{+3}$ present as $\mathrm{MnO}_{2}, \mathrm{Mn}_{2} \mathrm{O}_{3}$, and $\mathrm{Mn}_{3} \mathrm{O}_{4}$ and/or hydrous complexes in the feed to $\mathrm{Mn}^{+2}$ as $\mathrm{Mn}(\mathrm{COOH})_{2}$ so that $\mathrm{O}_{2}$ is not liberated when $\mathrm{Mn}^{+4}$ species enter the melter $[4,5,14,32]$

- $\quad$ steam strip mercury for subsequent removal, $\mathrm{HgO} \rightarrow \mathrm{Hg}^{0}$; and

- improve slurry rheology by neutralizing excess hydroxide $\left(\mathrm{OH}^{-}\right)$in the feed.

While nitric acid can be used to control feed rheology and destroy carbonates, only a reducing acid such as formic acid can convert $\mathrm{HgO} \rightarrow \mathrm{Hg}^{\circ}$ and convert $\mathrm{MnO}_{2} \rightarrow \mathrm{MnO}+1 / 2 \mathrm{O}_{2}$ in the SRAT. Currently, the REDOX equilibrium in DWPF is controlled by balancing formic acid (a reductant) and nitric acid (an oxidizer) additions to the SRAT using the EE REDOX model developed in 2003 [15]. The SRAT product is then fed to the DWPF SME, where a borosilicate glass frit slurry is added to produce the melter feed slurry. The melter feed slurry is typically concentrated to $45-50 \mathrm{wt} \%$ total solids in the SME and then fed to the DWPF joule-heated melter where it is fused into glass (vitrified) at $1150^{\circ} \mathrm{C}$.

\subsection{DWPF REDOX Control Limits for Foam Minimization}

The REDOX equilibria for DWPF borosilicate glasses were studied by Schreiber [22,33,34,35]. Schreiber developed an electromotive force (EMF) series for DWPF glasses that correlates a given oxygen fugacity to the ratio of the reduced to oxidized species in a glass for all REDOX sensitive multi-valent species such as $\mathrm{Mn}, \mathrm{Fe}, \mathrm{Ni} \mathrm{Cr}, \mathrm{Cu}, \mathrm{U}, \mathrm{S}$, etc (Figure 2). The EMF series was determined in small furnaces where the oxygen fugacity $\left(f_{\mathrm{O}_{2}}\right)$ of the vapor in equilibrium with a melt was controlled by varying gas mixtures at a constant melt temperature of $1150^{\circ} \mathrm{C}$. Therefore, the EMF series is independent of melter feed additives, e.g. oxidizers and/or reductants.

The EMF series allows the estimation of the REDOX state of all REDOX pairs present based on the measurement of only one REDOX ratio in DWPF glass, e.g. $\mathrm{Fe}^{+2} / \sum\left(\mathrm{Fe}^{+2}+\mathrm{Fe}^{+3}\right)$. Schreiber measured the $\mathrm{Fe}^{+2} / \sum\left(\mathrm{Fe}^{+2}+\mathrm{Fe}^{+3}\right)$ couple at $1 \% \mathrm{Fe}, 5 \% \mathrm{Fe}$, and $10 \% \mathrm{Fe}$ in a borosilicate frit and found that the total Fe concentration moved the $\mathrm{Fe}^{+2} / \sum\left(\mathrm{Fe}^{+2}+\mathrm{Fe}^{+3}\right)$ couple. Since DWPF glasses contain between $12-14 \mathrm{wt} \% \mathrm{Fe}_{2} \mathrm{O}_{3}$, the $10 \mathrm{wt} \% \mathrm{Fe}\left(\sim 14.3 \mathrm{wt} \% \mathrm{Fe}_{2} \mathrm{O}_{3}\right)$ correlation determined by 
Schreiber is normally used. In other words, the measurement of the $\mathrm{Fe}^{+2} / \sum\left(\mathrm{Fe}^{+2}+\mathrm{Fe}^{+3}\right)$ ratio allows one to determine the oxygen fugacity $f_{\mathrm{O}_{2}}$ of the DWPF melt and the oxidation states of all the other REDOX pairs. For example, in Figure 2 when the $\mathrm{Fe}^{+2} / \sum\left(\mathrm{Fe}^{+2}+\mathrm{Fe}^{+3}\right)$ is $0.09(9 \%$ of all the Fe present is reduced to $\mathrm{Fe}^{+2}$ ), the $\log f_{\mathrm{O}_{2}}$ is -3.5 and $98 \%$ of all the $\mathrm{Mn}^{+3}$ present is reduced to $\mathrm{Mn}^{+2}$.

Schreiber's experimental data indicated that the oxygen fugacities in DWPF waste glass melters at $1150^{\circ} \mathrm{C}$ should be maintained between $f_{\mathrm{O}_{2}}$ values of $10^{-2}$ and $10^{-7}$ atm to simultaneously avoid foaming due to deoxygenation of transition metal species and metal precipitation [22]. This was based on bounding cases of $1 \mathrm{wt} \% \mathrm{Fe}$ and $10 \mathrm{wt} \% \mathrm{Fe}$. Goldman's 1986 data, in support of the West Valley Fuel Services (WVFS) melter, recommended that the oxygen fugacity be controlled between $f_{\mathrm{O}_{2}}$ values of $10^{-4}$ to $10^{-7}$ atm [23]. Schreiber's publication specifically stated that "a melter must be operated at oxygen fugacities lower (more reduced) than $f_{\mathrm{O}_{2}}=10^{-2} \mathrm{~atm}$ in order to eliminate the oxidized states of manganese, cerium, and chromium as the cause of melter foaming" but his final oxidized waste processing limit was recommended at $10^{-4}$ atm to be conservative [22].

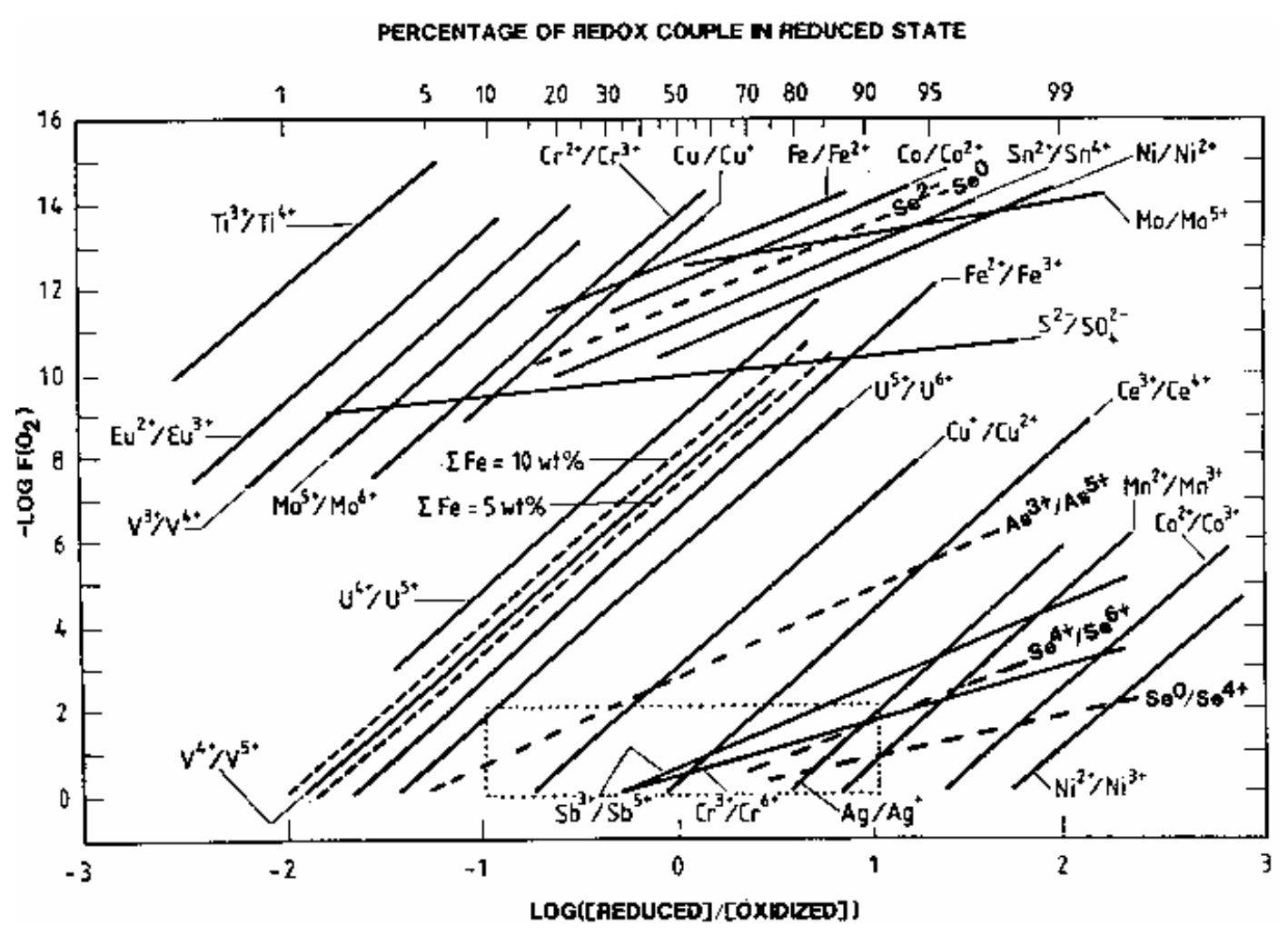

Figure 2. Electromotive Force (EMF) series developed for DWPF glass at $1150^{\circ} \mathrm{C}$ [22]. 
Excess reduction of multi-valent species at the melt temperature was determined $[10,22]$ to cause the following to occur:

- liberation of oxygen which can cause foaming from decomposition of $\mathrm{Mn}^{+4}$ or $\mathrm{Mn}^{+3}$ species if they were not adequately reduced during SRAT processing

- reduction of metallic species such as $\mathrm{NiO} \rightarrow \mathrm{Ni}^{\circ}$ and $\mathrm{RuO}_{2} \rightarrow \mathrm{Ru}^{\circ}$ which may fall to the melter floor and cause shorting of electrical pathways in the melt and accumulations which may hinder glass pouring

- reduction of sulfate $\left(\mathrm{SO}_{4}{ }^{\circ}\right)$ to sulfide $\left(\mathrm{S}^{=}\right)$which can complex with $\mathrm{Ni}^{\circ}$ and $/$ or $\mathrm{Fe}^{\circ}$ to form metal sulfides which can fall to the melter floor and cause shorting of electrical pathways and/or hinder glass pouring

- reduced glasses $\left(>0.33 \mathrm{Fe}^{+2} / \Sigma \mathrm{Fe}\right)$ which can be less durable than their oxidized equivalents [36].

Schreiber recommended routine measurement of the $\mathrm{Fe}^{+2} / \mathrm{Fe}^{+3}$ or $\mathrm{Fe}^{+2} / \sum \mathrm{Fe}$ of a glass as the most accurate methodology by which the oxygen fugacity in a melt could be evaluated [35]. Glass REDOX measurement was shown to be more accurate than $f_{\mathrm{O}_{2}}$ measurement based on the use of oxygen probes in the melt or melt plenum.

Based on Schreiber's correlation of iron REDOX with oxygen fugacity, a glass with an iron REDOX ratio $\left(\mathrm{Fe}^{+2} / \sum \mathrm{Fe}\right.$ ) between 0.09 (at $10 \% \mathrm{Fe}$ ) and 0.33 (at $10 \% \mathrm{Fe}$ ) provides the bounding $f_{\mathrm{O}_{2}}$ range between $10^{-4}$ and $10^{-7}$ atm in the melter plenum and, hence, the optimum operating range to prevent foaming and metal precipitation. These conditions keep $98 \%$ of the $\mathrm{Mn}$ present as $\mathrm{Mn}^{+2},>97 \%$ of the $\mathrm{Cr}$ present as $\mathrm{Cr}^{+3}, \approx 100 \%$ of the $\mathrm{Ni}$ present as $\mathrm{Ni}^{+2}, 70-95 \%$ of the $\mathrm{Cu}$ present as $\mathrm{Cu}^{+}, 90-97 \%$ of the Ce present at $\mathrm{Ce}^{+3}, 25-65 \%$ of the $\mathrm{U}^{+6}$ present as $\mathrm{U}^{+5}$, and $5-25 \%$ of the $\mathrm{U}^{+5}$ present as $\mathrm{U}^{+4}$. Iron REDOX ratios $\left(\mathrm{Fe}^{+2} / \sum \mathrm{Fe}\right)$ less than 0.09 will cause foaming due to deoxygenation of multi-valent metal species and $\mathrm{Fe}^{+2} / \sum \mathrm{Fe}$ ratios greater than 0.33 will cause metallic and or metallic sulfides to precipitate [10]. The lower REDOX limit eliminates melter foaming primarily from $\mathrm{Mn}^{+3}$ deoxygenation.

Jantzen and Plodinec [37] compared the recommendations of Schreiber [22], Goldman [23], Hrma [4], and others [39] and recommended that the DWPF REDOX ratio based on $\mathrm{Fe}^{+2} / \Sigma \mathrm{Fe}$ be controlled between 0.09 and 0.33 (i.e., the corresponding oxygen fugacity range of $10^{-4}$ to $10^{-7}$ atm at $10 \mathrm{wt} \% \mathrm{Fe})$.

Confirmation of the impact of REDOX on DWPF melt rate was made by Smith and others in 2004-2005 [17,38]. A specially designed melt rate furnace (MRF) was used to show a direct correlation between REDOX, foaming, and melt rate. At a Fe $\mathrm{Fe}^{+2} / \Sigma \mathrm{Fe}$ of 0.1 and above the melt rate was maximized while the melt rate decreased significantly $(\geq 25 \%)$ at $\mathrm{Fe}^{+2} / \Sigma \mathrm{Fe}$ of $\leq 0.1$.

It should also be noted that [39] foaming and reboil were determined to be a strong function of oxygen fugacity in the melts of simple two component glasses $\left(\mathrm{Na}_{2} \mathrm{O}-\mathrm{SiO}_{2}\right)$ that contain no 
REDOX active species such as $\mathrm{Mn}$ and Fe. Foaming and reboil both decreased in this simple two component glass as the oxygen fugacity decreased, i.e. became more reduced than $10^{-2} \mathrm{~atm}$. In these experiments, the oxygen partial pressures ranged from $10^{-2}$ to $10^{-12}$ atmospheres and were controlled by varying gas mixtures. Bubble stability and foaming were shown to be minimized at oxygen fugacities more reduced than $10^{-12}$ atmospheres.

The effects of melt temperature and oxygen fugacity on the speciation of $\mathrm{Mn}$ and Fe oxides in steelmaking furnaces were also studied in the laboratory where the oxygen fugacity $\left(f_{\mathrm{O}_{2}}\right)$ of the vapor in equilibrium with the molten oxide was controlled by varying gas mixtures at various melt temperatures [40]. Figure 3 shows that at a constant oxygen fugacity $\left(\mathrm{fO}_{2}\right)$ reduced species become more thermodynamically stable with increasing temperature relative to their oxidized counterparts. For example, the stable form of manganese oxide at $1150^{\circ} \mathrm{C}$ in the presence of atmospheric air $\left(f O_{2}=10^{-0.7}=0.21 \mathrm{~atm}\right)$ is $\mathrm{Mn}_{3} \mathrm{O}_{4}$ with a mixed +2 and +4 valence $\left(\mathrm{Mn}_{3} \mathrm{O}_{4}=\right.$ $2 \mathrm{MnO} \cdot \mathrm{MnO}_{2}$ ). At temperatures higher than $\sim 1500^{\circ} \mathrm{C}$, only $\mathrm{MnO}$ remains stable. Therefore, when simulated wastes containing $\mathrm{Mn}^{+4}$ species such as $\mathrm{MnO}_{2}$ or $\mathrm{Mn}(\mathrm{OH})_{4}$ are fed to the DWPF melter at $1150^{\circ} \mathrm{C}$, an autocatalytic deoxygenation of $2 \mathrm{MnO}_{2} \rightarrow \mathrm{MnO}_{3}\left(\mathrm{MnO}_{2} \bullet \mathrm{MnO}\right)+1 / 2 \mathrm{O}_{2}$ or $3 \mathrm{MnO}_{2} \rightarrow \mathrm{MnO}_{4}\left(2 \mathrm{MnO} \cdot \mathrm{MnO}_{2}\right)+\mathrm{O}_{2}$ occurs. This liberates oxygen and causing the production of an oxygen rich foam while the melt approaches thermodynamic equilibrium $[4,5,6]$ unless the oxidized manganese species in the feed are converted to $\mathrm{Mn}^{+2}$.

While Figure 3 shows that at $1150^{\circ} \mathrm{C} \mathrm{Mn}_{3} \mathrm{O}_{4}$ is stable at an oxygen fugacity of $0.21 \mathrm{~atm}$, Hrma showed experimentally that $\mathrm{Mn}_{3} \mathrm{O}_{4}$ reacted with Frit 165 at this temperature and liberated considerable oxygen [5]. This is because the stability fields for $\mathrm{Mn}_{3} \mathrm{O}_{4}$ shown in Figure 3 actually represent a continuum of mixtures of manganese oxides with +2 and +3 valence. This can be visualized by taking the ratios of $\mathrm{Mn}^{+2} / \sum\left(\mathrm{Mn}^{+2}+\mathrm{Mn}^{+3}\right)$ ratios from Figure 2 and plotting these values at $1150^{\circ} \mathrm{C}$ on Figure 3 at their respective $\log f \mathrm{O}_{2}$ values. In this manner, one can see that at point 1 the ratio of $\mathrm{Mn}^{+2} / \sum\left(\mathrm{Mn}^{+2}+\mathrm{Mn}^{+3}\right)$ is 0.9 , at point 2 the ratio is 0.95 , and at point 3 the ratio is 0.98 . Thus, there is a family of curves between the stability boundaries given by the $\mathrm{Mn}_{2} \mathrm{O}_{3}: \mathrm{Mn}_{3} \mathrm{O}_{4}$ and $\mathrm{Mn}_{3} \mathrm{O}_{4}: \mathrm{MnO}$ equilibria shown in Figure 3.

Hrma [4,5] developed the following equation to demonstrate how oxygen liberation due to the reduction of $\mathrm{Mn}_{3} \mathrm{O}_{4}\left(1 \mathrm{MnO}_{2} \bullet 2 \mathrm{MnO}\right)$ to a mixture more rich in $\mathrm{MnO}$ could cause foaming in DWPF type glasses.

\section{Equation 1}

$$
(p) \mathrm{MnO}_{\frac{4}{3}}+(1-p) \mathrm{MnO} \stackrel{\stackrel{\text { Melt }}{\text { Dissolution }} \longrightarrow}{\longrightarrow}(1-q) \mathrm{MnO}+(q) \mathrm{MnO}_{\frac{3}{2}}+\frac{1}{12}(2 p-3 q) \mathrm{O}_{2}
$$

where $\mathrm{p}=$ molar fraction of $\mathrm{MnO}$ in a mixture of calcined $\mathrm{MnO}+\mathrm{Mn}_{3} \mathrm{O}_{4}$ before melting $\mathrm{q}=$ equilibrium molar fraction of $\mathrm{Mn}_{2} \mathrm{O}_{3}$ in the $\mathrm{MnO}+\mathrm{Mn}_{3} \mathrm{O}_{4}$ mixture dissolved in the 
melt which is independent of pressure, dependent on temperature, dependent on the fugacity of oxygen, $\mathrm{fO}_{2}$, and dependent on the composition the melt.

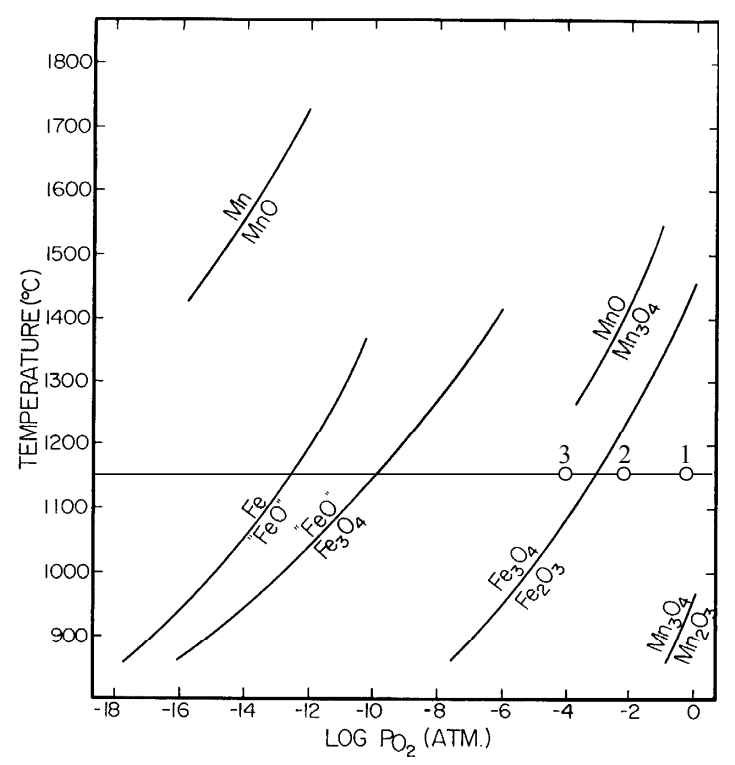

Figure 3. Comparison of stability relations among the oxides of iron and manganese as a function of temperature and oxygen partial pressure [40].

Oxygen is consumed in Equation 1 if $p<3 / 2 q$. Oxygen is liberated if $p>3 / 2 q$. If $p=3 / 2 q$ then the $\mathrm{Mn}^{2+} / \mathrm{Mn}^{3+}$ ratio of the batch is equal to that at equilibrium with the molten frit. The temperature dependence of the manganese REDOX equilibria is expressed by combining Equation 1 and Figure 3: differences in temperature within a melter can cause differences in the $\mathrm{fO}_{2}$ equilibrium within the melt pool. More oxygen is liberated if all of the manganese on the LHS of Equation 1 is $\mathrm{MnO}_{2}$ or $\mathrm{Mn}_{2} \mathrm{O}_{3}\left(\mathrm{MnO}_{2} \bullet \mathrm{MnO}\right)$. Because $\mathrm{Mn}_{3} \mathrm{O}_{4}$ is $1 \mathrm{MnO}_{2}$ and $2 \mathrm{MnO}$ this was translated [4,5] into a DWPF feed requirement that $66 \%$ of the $\mathrm{Mn}^{+4}$ (as $\mathrm{MnO}_{2}$ or other $\mathrm{Mn}^{+4}$ species) must be reduced to $\mathrm{Mn}^{+2}$ (as $\mathrm{MnO}, \mathrm{Mn}(\mathrm{COOH})_{2}, \mathrm{Mn}$ oxalate, etc) before the feed is melted in order to minimize or eliminate oxygen foam in the DWPF melter. The theoretical amount of oxygen released by oxidized uranium entering the melter as $\mathrm{U}^{+6}$ are given by Equation 2 and Equation 3 below [41]:

Equation 2

$$
\mathrm{U}_{2} \mathrm{O}_{6} \rightarrow 0.9 \mathrm{UO}_{3}+0.45 \mathrm{U}_{2} \mathrm{O}_{5}+0.2 \mathrm{UO}_{2}+0.325 \mathrm{O}_{2} \uparrow \text { at } \mathrm{Fe}^{2+} / \Sigma \mathrm{Fe}=0.09
$$

Equation 3

$$
\mathrm{U}_{2} \mathrm{O}_{6} \rightarrow 0.70 \mathrm{UO}_{3}+0.50 \mathrm{U}_{2} \mathrm{O}_{5}+0.30 \mathrm{UO}_{2}+0.40 \mathrm{O}_{2} \uparrow \text { at } \mathrm{Fe}^{2+} / \Sigma \mathrm{Fe}=0.33
$$

The maximum theoretical oxygen liberation in moles of $\mathrm{O}_{2}$ gas is summarized in Table 2 . 
Table 2. Maximum Theoretical Moles of Oxygen Released when Multi-Valent Species Entering a Melter are Reduced

\begin{tabular}{|c|c|c|}
\hline $\begin{array}{l}\text { Potential Oxidized } \\
\text { Species in Feed } \\
\text { and/or Cold Cap }\end{array}$ & $\begin{array}{c}\text { Reduced Species in Borosilicate Glass } \\
\text { in DWPF REDOX Range }\end{array}$ & $\begin{array}{c}\text { Maximum } \\
\text { Theoretical Moles } \\
\text { of } \mathrm{O}_{2} \text { Gas } \\
\text { Released Per Mole } \\
\text { of Multi-Valent } \\
\text { Species }\end{array}$ \\
\hline $\begin{array}{c}2 \mathrm{Mn}^{+2} \mathrm{O} \bullet 1 \mathrm{Mn}^{+4} \mathrm{O}_{2} \\
\left(\mathrm{Mn}_{3} \mathrm{O}_{4}\right)\end{array}$ & $99 \% \mathrm{MnO}$ & $0.17 / \mathrm{Mn}$ \\
\hline $\mathrm{Mn}_{2}^{+3} \mathrm{O}_{3}$ & $99 \% \mathrm{MnO}$ & $0.25 / \mathrm{Mn}$ \\
\hline $\mathrm{Mn}^{+4} \mathrm{O}_{2}$ & $99 \% \mathrm{MnO}$ & $0.50 / \mathrm{Mn}$ \\
\hline$(\mathrm{K}, \mathrm{Na}, \mathrm{Li})_{3} \mathrm{Mn}^{+5} \mathrm{O}_{4}$ & $99 \% \mathrm{MnO}$ & $0.75 / \mathrm{Mn}$ \\
\hline$(\mathrm{K}, \mathrm{Na}, \mathrm{Li})_{2} \mathrm{Mn}^{+6} \mathrm{O}_{4}$ & $99 \% \mathrm{MnO}$ & $1.00 / \mathrm{Mn}$ \\
\hline$(\mathrm{K}, \mathrm{Na}, \mathrm{Li}) \mathrm{Mn}^{+7} \mathrm{O}_{4}$ & $99 \% \mathrm{MnO}$ & $1.25 / \mathrm{Mn}$ \\
\hline $\begin{array}{c}\mathrm{Na}_{2} \mathrm{U}^{+6}{ }_{2} \mathrm{O}_{7} \\
\text { or } \mathrm{U}^{+6} \mathrm{O}_{3}\end{array}$ & $\begin{array}{c}\text { Mixed } \\
\mathrm{U}^{+6} \mathrm{O}_{3}+\mathrm{U}_{2} \mathrm{O}_{5}\left(\mathrm{U}^{+6} \mathrm{O}_{3}+\mathrm{U}^{+4} \mathrm{O}_{2}\right)+\mathrm{U}^{+4} \mathrm{O}_{2} \\
\text { (see Equation 2 and Equation 3) }\end{array}$ & $0.33 / \mathrm{U}$ to $0.42 / \mathrm{U}$ \\
\hline $\mathrm{Ce}^{+4} \mathrm{O}_{2}$ & $90-97 \% \mathrm{Ce}_{2}^{+3}{ }_{2} \mathrm{O}_{3}$ & $0.25 / \mathrm{Ce}$ \\
\hline $\mathrm{Cr}^{+6} \mathrm{O}_{3}$ & $>97 \% \mathrm{Cr}_{2}^{+3} \mathrm{O}_{3}$ & $0.75 / \mathrm{Cr}$ \\
\hline
\end{tabular}

Controlling the DWPF melter at a REDOX equilibrium of $\mathrm{Fe}^{+2} / \Sigma \mathrm{Fe} \leq 0.33[22,37]$ also prevents oxygen liberation from the potential conversion of $\mathrm{NiO} \rightarrow \mathrm{Ni}^{\circ}+1 / 2 \mathrm{O}_{2}, \mathrm{RuO}_{2} \rightarrow \mathrm{Ru}^{\circ}+\mathrm{O}_{2}$, and $2 \mathrm{SO}_{4}{ }^{=} \rightarrow 2 \mathrm{SO}_{2}+2 \mathrm{O}_{2 .}$. or $2 \mathrm{SO}_{4}{ }^{=} \rightarrow 2 \mathrm{~S}^{-2}+4 \mathrm{O}_{2}$ during vitrification. Control of foaming due to deoxygenation of manganic species is achieved by having $>66 \%$ of the $\mathrm{MnO}_{2}$ or $\mathrm{Mn}_{2} \mathrm{O}_{3}$ species converted to $\mathrm{MnO}[4,5]$ during SRAT refluxing as discussed above. Other multi-valent cations such as $\mathrm{U}^{+6}, \mathrm{Fe}^{+3}, \mathrm{U}^{+5}$, and $\mathrm{Ce}^{+4}$ can also generate $\mathrm{O}_{2}$ gas during reduction within the $\mathrm{Fe}^{+2} / \Sigma \mathrm{Fe}$ range of 0.09-0.33 as shown in Table 2.

\subsection{DWPF REDOX Model for Foam Minimization}

In the cold cap, decomposition, calcination and REDOX reactions occur. In the melt pool, further degassing and homogenization occur primarily by additional REDOX reactions $[27,42,43]$. The degassing can cause foam in the cold cap of the melt pool that is a mixture of glass and batch with entrained $\mathrm{CO}_{2}, \mathrm{O}_{2}, \mathrm{~N}_{2} \mathrm{O}, \mathrm{N}_{2}, \mathrm{H}_{2}$ or mixtures of these gaseous products as discussed in previous sections of this report. The gaseous products from the cold cap and the volatile feed components further react with air in the vapor space.

In order to represent the gradual nature of the feed-to-glass conversion, a 4-stage cold cap model was developed by Choi [44] which approximates the melting of feed solids as a continuous, 4stage countercurrent process. The temperature of each stage is set progressively higher from the top (cold cap-vapor space interface) to the bottom (cold cap-melt interface) as shown in Figure 4. 
Stage 1 represents the initial stage of melting before a melt appears. All oxides remain as solids, and each form an invariant condensed phase [42]. In Stage 1 the formated salts such as $\mathrm{NaCOOH}$ are decomposed to $\mathrm{CO}, \mathrm{CO}_{2}$ and $\mathrm{H}_{2}$ (see Figure 4). The $\mathrm{CO}$ and $\mathrm{H}_{2}$ subsequently react with the oxygen being liberated by $\mathrm{NaNO}_{3}$ and $\mathrm{NaNO}_{2}$ decomposing during Stages 1 and 2 and also with the oxygen generated as a result of REDOX reactions occurring in Stages 3 and 4, as discussed in Section 2.3 (see Figure 4). Thus the overall decomposition and calcination reactions occurring in Stages 1 and 2 of the cold cap are primarily responsible for the gas generation and foaming in the upper regions of the cold cap can be represented by the combined Equation 4:

Equation 4

$$
\begin{aligned}
& 2 \mathrm{NaCOOH}+2 \mathrm{NaNO}_{3} \rightarrow \mathrm{CO} \uparrow+\underset{\text { Stage } 1}{\mathrm{CO}_{2} \uparrow}+\mathrm{H}_{2} \uparrow+\mathrm{N}_{2} \uparrow+\underset{\text { Stage } 2}{2.5 \mathrm{O}_{2}} \uparrow+\underset{\text { Stage } 1+2}{2 \mathrm{Na}_{2} \mathrm{O}} \rightarrow
\end{aligned}
$$

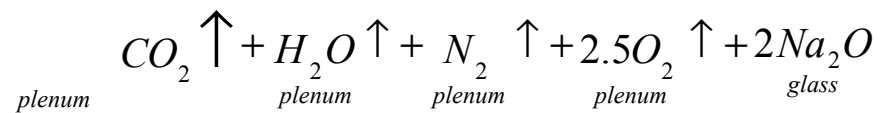

In Stage 2, all oxides are assumed to be in a liquid state and form a solution [42]. Silica and other non-REDOX species form one melt phase, and all REDOX species form the other. The model assumes that these two melt phases are in equilibrium with each other and with the gas and the invariant condensed phases.

Multiple oxides begin to form during Stage 3 reactions [44]. These oxides are of the spinel type such as $\mathrm{NiFe}_{2} \mathrm{O}_{4}$ and $\mathrm{MgFe}_{2} \mathrm{O}_{4}$. These oxides are assumed to form a solid solution and coexist with the REDOX species in the same phase. The gas phase at this elevated temperature contains only $\mathrm{O}_{2}$ and $\mathrm{SO}_{3}$. Stage 4 represents the final fusion where the oxides formed dissolve in a silica-rich matrix to form silicate groups in the melt (see Figure 4). The dominant forms of $\mathrm{Fe}^{+2}$ and $\mathrm{Fe}^{+3}$ in the glass, based on thermodynamic calculations, are $\mathrm{Fe}_{3} \mathrm{O}_{4}, \mathrm{FeO}, \mathrm{Fe}_{2} \mathrm{O}_{3}$, and $\mathrm{Fe}_{2} \mathrm{SiO}_{4}$ [44].

In addition, hydrogen can be liberated from decomposition of free $\mathrm{HCOOH}$ by reactions such as Equation 5:

Equation 5

$$
\underset{\text { feed additive }}{\mathrm{HCOOH}} \rightarrow \underset{\text { plenum }}{\mathrm{CO}_{2} \uparrow}+\underset{\text { plenum }}{\mathrm{H}_{2}} \uparrow
$$

The recent DWPF EE REDOX model $[15,16]$ of the cold cap oxidation/reduction equilibrium between nitrate and formate shown in Equation 6 indicates that one mole of nitrogen in nitrate gains 5 moles of electrons when it is reduced to $\mathrm{N}_{2}$ while one mole of carbon in formate loses 2 moles of electrons during oxidation to $\mathrm{CO}_{2}$. This is an oxidant:reductant ratio of 5:2 which indicates that nitrate is $2 \frac{1}{2}$ times as effective an oxidizing agent as formate is a reducing agent on an equal molar basis (when nitrogen gas is the reaction product). 
Equation 6

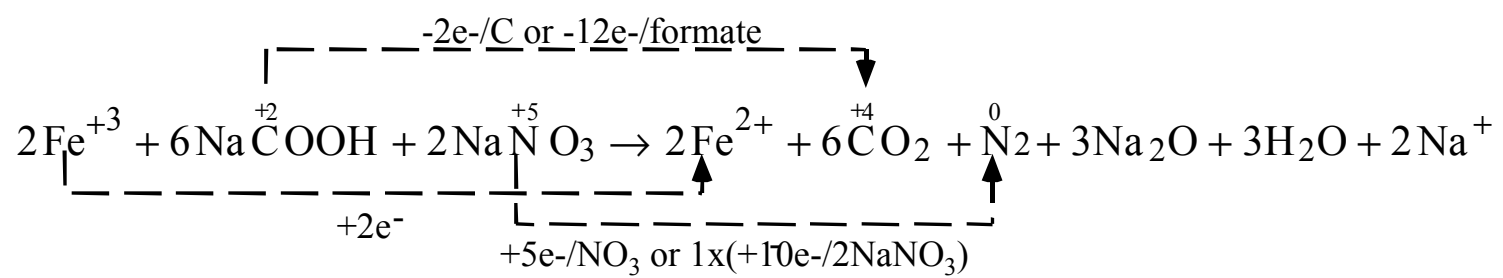

The EE REDOX model calculates the cold cap oxidation/reduction equilibrium shown in Equation 7 between coal and nitrated salts. Equation 7 shows that one mole of nitrogen in nitrate gains 5 moles of electrons when it is reduced to $\mathrm{N}_{2}$ while one mole of carbon in coal loses 4 moles of electrons during oxidation to $\mathrm{CO}_{2}$. This is an oxidant:reductant ratio of 5:4 which indicates that nitrate is only $1 \frac{1}{4}$ times as effective an oxidizing agent as coal is a reducing agent on an equal molar basis (when nitrogen gas is the reaction product).

Equation 7

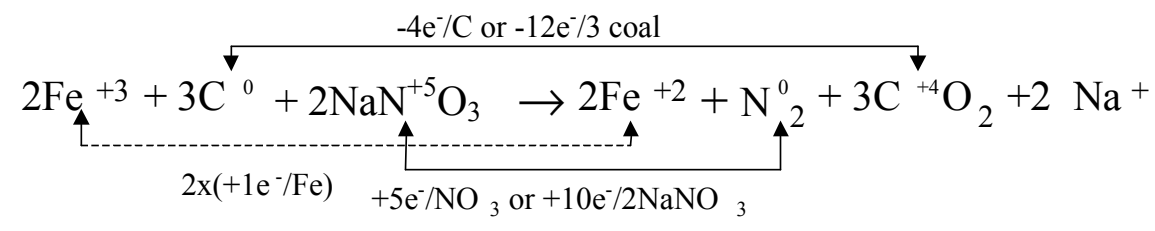

The EE REDOX model calculates a cold cap oxidation/reduction equilibrium shown between oxalate and nitrate salts. Theoretically, one mole of nitrate should gain 5 moles of electrons when it is reduced to $\mathrm{N}_{2}$ while the two moles of carbon in oxalate should lose 2 moles of electrons during oxidation to $\mathrm{CO}_{2}$. This is an oxidant:reductant ratio of 5:2 which indicates that nitrate is 2.5 times as effective an oxidizing agent as oxalate is a reducing agent (when nitrogen gas is the reaction product). However, experimental data indicated that oxalate appeared to be twice as strong a reductant as anticipated from Equation 7 [15]. During further investigation of the apparent increase in the reducing power of oxalate, data became available that demonstrated that oxalate salts convert to oxalic acid which then disproportionates to formate and $\mathrm{CO}_{2}$ during SRAT processing [45] via the following reaction:

$$
\mathrm{HC}_{2}^{+3} \mathrm{O}_{4}^{-} \rightarrow \mathrm{HC}^{+2} \mathrm{O}_{2}^{-}+\mathrm{CO}_{2} \uparrow
$$




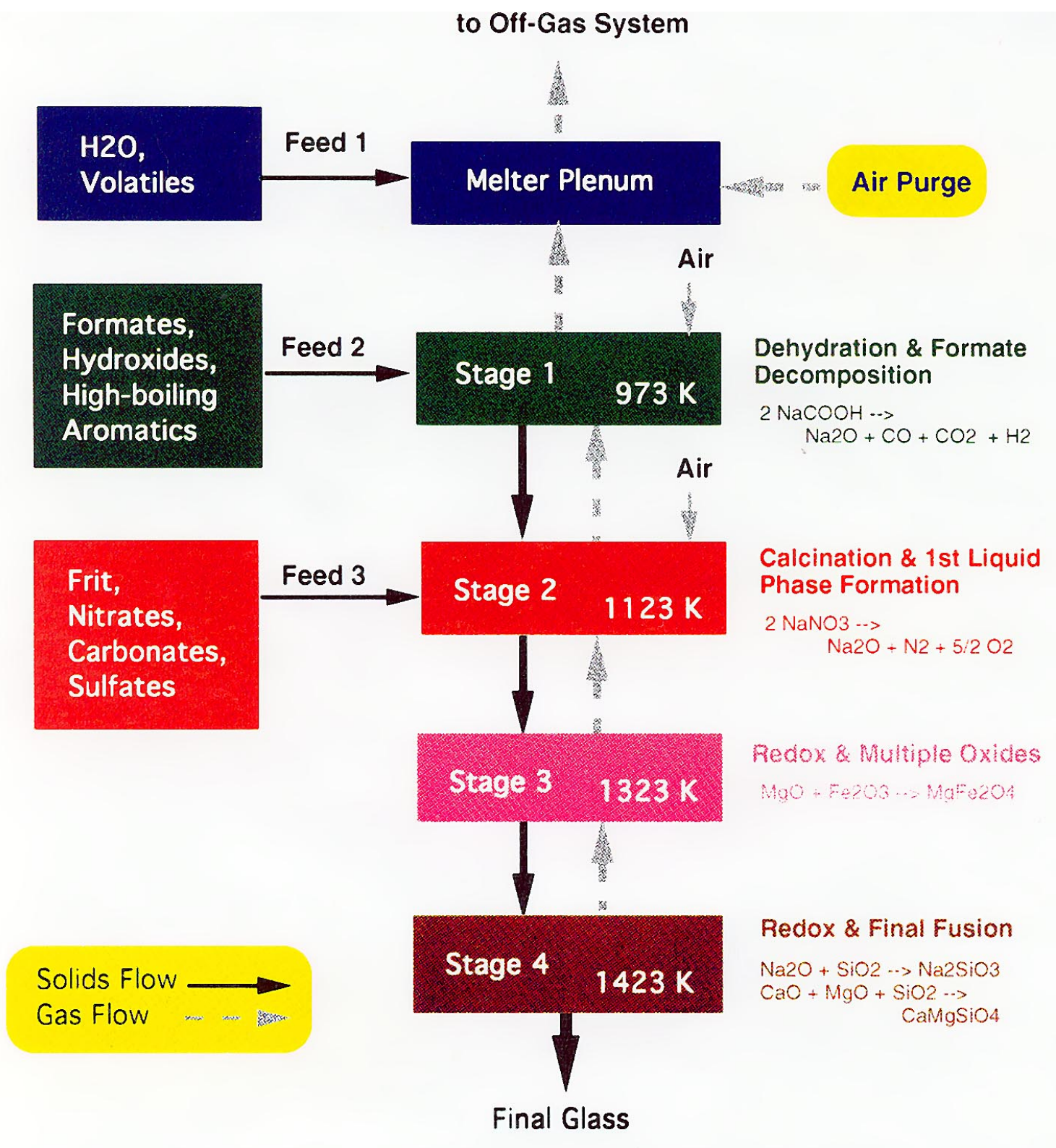

Figure 4. Four stage DWPF cold cap model from Choi $[27,43,44]$. 
Experimentally, it was determined that between $8-37 \%$ of the oxalate present in the SRAT disproportionated into $\mathrm{COOH}^{-}$and $\mathrm{CO}_{2}$ [45]. Therefore, it was assumed that additional disproportionation occurs in the cold cap when the liquid slurry impacts the melt pool surface. The pertinent oxidation/reduction equilibrium for oxalate, including the disproportionation, assumed [15] that only half the oxalate acts as a reductant (the half that disproportionates does not affect the REDOX equilibrium). Hence, the reduction potential of oxalate is doubled and the effective oxidant:reductant ratio is 5:4, i.e. nitrate is $1 \frac{1 / 4}{4}$ times as effective an oxidizing agent as oxalate is a reducing agent (when nitrogen gas is the reaction product).

An EE REDOX model term was also developed [15] for the reduction of manganese by any carbon containing reductant. The EE REDOX model term developed assumed a worst case, i.e. that all the manganese entered the melter as $\mathrm{Mn}^{+4}$ either from the sludge where it has can be present as $\mathrm{Mn}(\mathrm{OH})_{4}$ or $\mathrm{MnO}_{2}$ [46] or from SRAT processing. The assumption that all the manganese was present as $\mathrm{Mn}^{+4}$ was considered conservative as it is known that HLW sludge species can include $\mathrm{Mn}^{+3}$ as $\mathrm{Mn}^{+3} \mathrm{OOH}, \mathrm{Mn}_{3} \mathrm{O}_{4}$ (mixed $\mathrm{Mn}^{+4}$ and $\left.\mathrm{Mn}^{+2}\right)$, jacobsite $\left(\mathrm{Fe}_{2} \mathrm{MnO}_{4}\right)$, and mixed unidentified Fe-Mn oxides/hydroxides [46]. In addition, manganous oxalate has recently been found during the Differential Scanning Calorimetry (DSC) analysis of Tank 7 sludges.

During DWPF SB3 SRAT processing, the distribution of the soluble manganese, that is $\mathrm{Mn}^{+2}$, showed no relation to any combination of feed oxidizers or reductants. A relationship cannot be determined because manganese can complex with formate as soluble $\mathrm{Mn}(\mathrm{COOH})_{2}$ in the SRAT supernates, as insoluble $\mathrm{Mn}^{+4} \mathrm{O}_{2}$, manganous oxalate $\left(\mathrm{Mn}^{+2} \mathrm{C}_{2} \mathrm{O}_{4} \bullet 2 \mathrm{H}_{2} \mathrm{O}\right)$, and/or manganous sulfate $\left(\mathrm{Mn}^{+2} \mathrm{SO}_{4}\right)$ in the SRAT insoluble solids [15]. Therefore, a measurement of the soluble $\mathrm{Mn}$ in the SRAT supernate is insufficient to determine if $66 \%$ of the $\mathrm{Mn}^{+4}$ has been reduced to $\mathrm{Mn}^{+2}$ to prevent foaming.

Since the distribution of $\mathrm{Mn}^{+2} / \mathrm{Mn}^{+3} / \mathrm{Mn}^{+4}$ in the DWPF SRAT product cannot be easily determined and the REDOX ratio was found to be highly dependent on the molar concentration of $\mathrm{MnO}$ in a glass during SB3 testing $[15,16]$, a manganese term was included in the DWPF EE REDOX model. The manganese was conservatively assumed to be all $\mathrm{Mn}^{+4}$ and Equation 8 used to determine the electron transfers between $\mathrm{Mn}^{+4}$ conversion to $\mathrm{Mn}^{+2}$ in the cold cap.

Equation 8

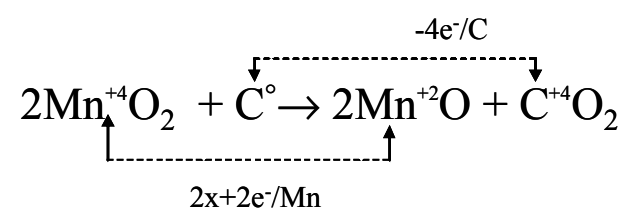

* Fernando Fondeur, personal communication February 28, 2003 
In summary the 2003 EE REDOX model [15] assumes the following number of electrons gained during reduction or lost during oxidation:

- $\left[\mathrm{NO}_{3}\right]=+5$

- $[\mathrm{Mn}]=+2$

- $[\mathrm{C}]_{\text {formate }}=-2$

- $[\mathrm{C}]_{\text {coal }}=-4$

- $[\mathrm{C}]_{\text {oxalate }}=-4$

- $[\mathrm{C}]_{\text {sugar }}=-4$

The water content of a melter feed alters the species concentrations of the [reductants] and [oxidants] and can influence the equilibrium oxygen fugacity $\left(f_{\mathrm{O}_{2}}\right)$ in a melter during vitrification. Since the effects of water on oxygen fugacity are small relative to the impact of dilution on feed concentrations, the molar concentrations were transformed to a $45 \%$ solids basis as was done in the 1998 REDOX modeling [12].

The overall relationship developed in 2003 [15] between the REDOX ratio and the electron equivalents, $\xi$, transferred was:

Equation 9

$$
\frac{F e^{2+}}{\Sigma F e}=f\left[\left(2[F]+4[C]+4\left[\mathrm{O}_{\mathrm{T}}\right]-5[N]-2[M n]\right) \frac{45}{T}\right]=f[\xi]
$$

where $\quad f=$ indicates a function

$[\mathrm{F}]=$ formate $(\mathrm{mol} / \mathrm{kg}$ feed $)$

$[\mathrm{C}]=\operatorname{coal}$ (carbon) $(\mathrm{mol} / \mathrm{kg}$ feed $)$

$\left[\mathrm{O}_{\mathrm{T}}\right]=$ oxalate $_{\text {Total }}($ soluble and insoluble $)(\mathrm{mol} / \mathrm{kg}$ feed $)$

$[\mathrm{N}]=$ nitrate + nitrite $(\mathrm{mol} / \mathrm{kg}$ feed $)$

$[\mathrm{Mn}]=$ manganese $(\mathrm{mol} / \mathrm{kg}$ feed $)$

$\mathrm{T}=$ total solids $(\mathrm{wt} \%)$

$\xi=\left(2[F]+4[C]+4\left[\mathrm{O}_{\mathrm{T}}\right]-5[N]-2[M n]\right) \frac{45}{T}$

When regressed against the data available as a linear function of $\xi$ :

$\frac{F e^{2+}}{\Sigma F e}=b+m \xi$ or $\frac{F e^{2+}}{\Sigma F e}=0.1942+0.1910 \xi$ with an $\mathrm{R}^{2}=0.81$ and $\mathrm{RMSE}=0.069$ 
The fit of the Electron Equivalents model for the 120 data points is about the same as the DWPF $\{[\mathrm{F}]-3[\mathrm{~N}]\}$ and $\{[\mathrm{F}]-[\mathrm{N}]\}$ REDOX models which had $\mathrm{R}^{2}$ values of 0.88 and 0.80 , respectively.

During validation of the DWPF EE model $[15,16]$ against production melter data from melters that used sugar as a reductant, a term for sugar was added to the EE REDOX model and this derivation can be found elsewhere $[15,16]$.

The EE REDOX model was validated against data from the DWPF production melter, data from the West Valley production melter, data from various pilot scale melters, and data from the Slurry Fed Melt Rate Furnace (SMRF) $[15,16]$.

The REDOX data collected from pilot scale melters before DWPF startup (the data used to develop the F-3N REDOX model in Figure 5), from SB3 crucible studies (indicated by open circles in Figure 5), data from the DWPF after radioactive startup (SME 224 in Figure 5), and from the SMRF (SB3 in Figure 5) and minimelter (SB2 in Figure 5) are shown in Figure 5. All of the production scale, pilot scale, minimelter, and SMRF data fit the EE REDOX model shown in Figure 5

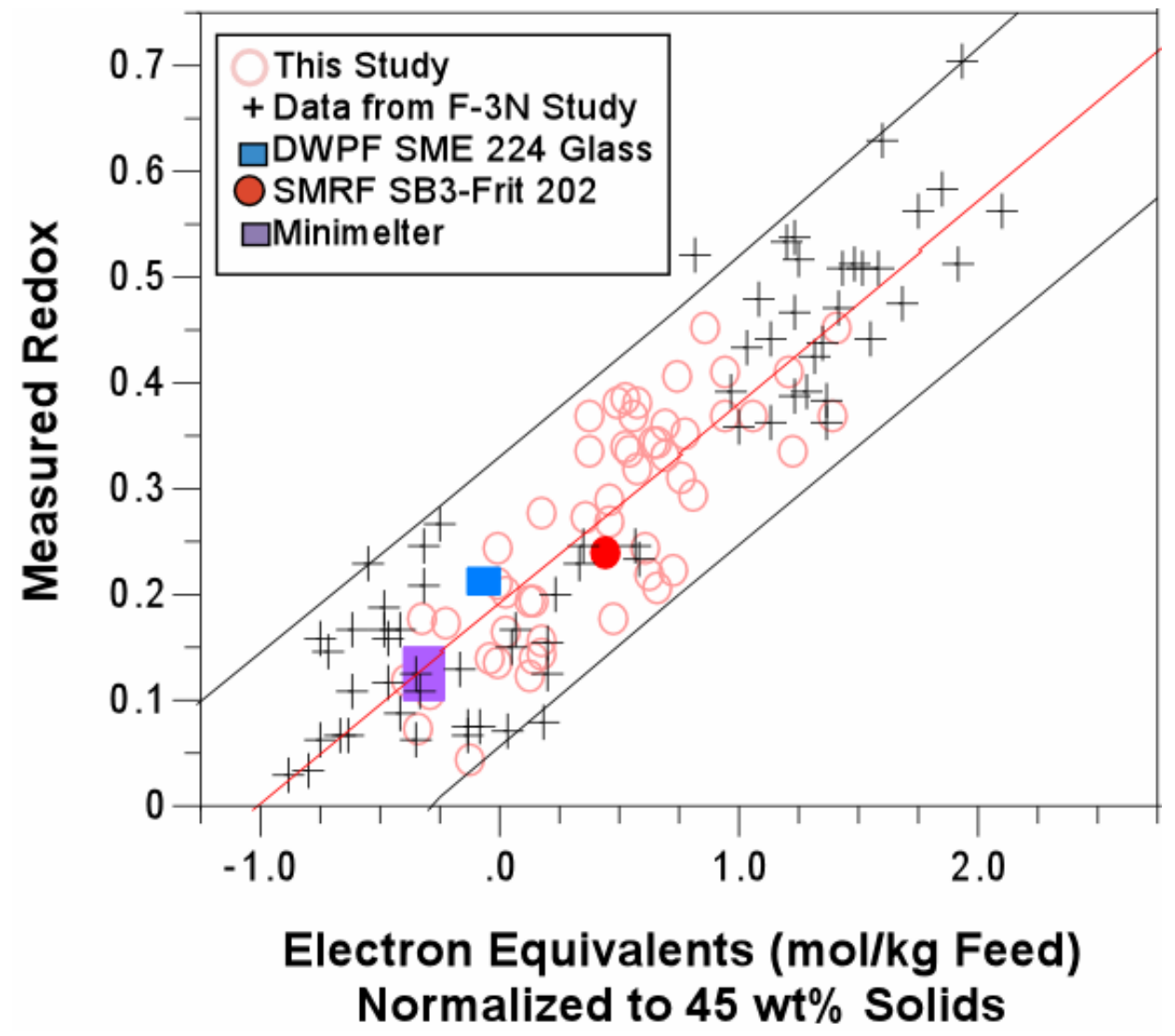

Figure 5. Measured REDOX data from pilot scale melters, crucible studies, SMRF studies and the DWPF Production melter. The calculations were performed based on the SME composition results adjusted to $45 \mathrm{wt} \%$ solids. 


\subsection{Gas-Glass Disequilibrium in Production Melters}

Even with reduction of multi-valent species during melter pre-processing and foam minimization by REDOX control, oxygen gas is still present in glass melts in three forms: (1) physically dissolved up to the solubility limit, (2) chemically dissolved with multi-valent metal ions or REDOX species, and (3) as gas bubbles. The data for the Schreiber EMF series were collected by remelting glass samples of less than 1 gram in a furnace under a controlled atmosphere and by directly measuring the concentrations of REDOX species that are in equilibrium with the vapor phase. Under these conditions, the only form of oxygen gas that needs to be accounted for in the REDOX equilibrium is that chemically bonded to specific REDOX species. In large-scale production melters, however, the other two forms of oxygen gas must also be considered since the vapor-melt equilibrium is now local, i.e., between a REDOX species at a specific location of the melt pool and the concentration of physically dissolved oxygen local to that REDOX species in consideration. Specifically, local equilibrium must be considered instead of the global equilibrium between the entire melt and the vapor above it.

So, in the case of an oxidizing melt, as the temperature is increased, the REDOX species will give up oxygen molecules which then diffuse through the melt to the nearest gas bubble, thereby causing it to grow. Large bubbles eventually would attain buoyancy forces large enough to overcome the head pressure caused by the depth of the melt pool and ascend leaving only the smaller bubbles. In the case of a reducing melt, the direction of oxygen transfer would be exactly reversed. The static pressure inside a gas bubble is determined by the vapor pressure over the melt, the head pressure, and the surface tension. For the DWPF melter, the static pressure at $3 \mathrm{ft}$ below the melt surface is estimated to be about 1.3 atmospheres, and the fugacity of oxygen for oxidizing melts could be well over 1 atmosphere.

When the REDOX equilibrium is disturbed due to process upsets such as temperature changes, a REDOX pair would quickly re-establish chemical equilibrium with the local concentration of physically dissolved oxygen in the melt. Upon a decrease in melt temperature, for example, REDOX species will be oxidized by consuming dissolved oxygen in order to maintain chemical equilibrium, thereby initially lowering the local concentration of physically dissolved oxygen. As a result, oxygen will begin to diffuse from nearby bubbles to melts local to the REDOX species.

The concentration of physically dissolved oxygen is proportional to the equilibrium oxygen pressure at that location in the melt, and the proportionality constant is the solubility of oxygen as determined by Henry's Law. Since the solubility of gases increases with increasing pressure at a constant temperature, the concentration of physically dissolved oxygen near the bottom of the melt pool would be higher than that near the melt surface due to higher head or hydrodynamic pressure. Although the physical solubility of gases is nearly independent of temperature, the chemical solubility of oxygen is quite sensitive to changes in temperature since the equilibrium constants for the REDOX reactions are strongly temperature dependent.

Therefore, if the melt temperatures are lower near the bottom of the melt pool than near the surface, this increases the concentration of chemically dissolved oxygen in the melt at the bottom 
of the melt pool. As a result, depth coupled with cooler bottom temperatures would tend to retard the degassing or release of excess oxygen from the oxidizing melt by increasing both physical and chemical solubilities of oxygen in the melt. This insufficient degassing would increase the concentration of undissolved gases in the melt in the form of small bubbles. If present in large quantities, many of those small bubbles would be released during pouring and reboil could occur.

\subsection{HISTORICAL MELTER EXPERIENCES WITH FOAMING}

\subsection{Savannah River Site}

Prior to 1982, the DWPF flow sheet contained one reductant, formic acid, to control foaming due to deoxygenation of $\mathrm{Mn}$ and other multi-valent species. The formic acid was added to the SRAT and SME to ensure that all the $\mathrm{Mn}$ was reduced to $\mathrm{Mn}^{+2}$ prior to vitrification. Too much reductant caused other species in the glass to be overly reduced, e.g. too much formic acid caused glasses to have $\mathrm{Fe}^{+2} / \sum \mathrm{Fe}$ ratios $>0.33$ and precipitate metallic $\mathrm{Ni}$ and $\mathrm{Ni}_{3} \mathrm{~S}_{2}[10]$.

In late 1982, an in-tank process for the removal of cesium, strontium, and plutonium from the aqueous fraction of the waste prior to it entering the DWPF was developed. The precipitating agent used was sodium tetraphenylborate (TPB). During the hydrolysis process in the DWPF Salt Processing Cell, formic acid and copper (as a catalyst) were added so that the TPB precipitates would hydrolyze completely to minimize the potential for off-gas flammability in the melter off-gas system.

During testing of the DWPF sludge only process and the "coupled" sludge plus Precipitate Hydrolysis Aqueous (PHA) product in the DWPF Scale Glass Melter (SGM), no foaming was observed (see Table I, SGM Campaigns 1 through 10) $[47,48,49,50,51]$ as the PHA contained additional organics. Glasses varied from $0.05-0.52 \mathrm{Fe}^{+2} / \sum \mathrm{Fe}$ indicating that in many cases the glass was overly reduced. However, no evidence of $\mathrm{Ni}^{\circ}$ precipitation or foaming was observed.

In 1986, sodium nitrite, an oxidizer, was added to the precipitate feed tank in large quantities to act as a corrosion inhibitor [52]. Late washing of the TPB precipitate feed to remove the added nitrite rather than allowing it to enter the DWPF was proposed. Alternatively, the addition of hydroxylamine nitrate (HAN) was proposed to reduce the nitrite to nitrous oxide (as well as mitigate formation of high-boiling organic compounds and tars). During pilot-scale testing of the HAN process, it was determined that the HAN process did not mitigate the high-boiling organics sufficiently and that the glasses produced were highly oxidized due to the high nitrite and nitrate. The HAN process was abandoned and the late washing alternative pursued.

In 1991 a more oxidizing DWPF flow sheet, the nitric acid flow sheet [53,54], was developed to minimize $\mathrm{H}_{2}$ production caused by the reaction of excess formic acid with noble metals in the feed $[14,55]: \mathrm{H}_{2}$ production was to be minimized for safety concerns. Basically, nitric acid was substituted for a portion of the formic acid required for waste pretreatment. The nitric acid flow sheet added considerable additional oxidizers to the DWPF feeds such as $\mathrm{HNO}_{3}$. 
During testing of these various flow sheets in the Integrated DWPF Melter System (IDMS), the only melter campaign reported $[56,57,58,59,60]$ to experience uncontrolled pouring problems caused by a foaming event was the HM-4 Campaign. For this campaign, the nitric acid flow sheet was coupled with the HAN-type ${ }^{1}$ high nitrate PHA [54]. No foaming was observed during testing of the remaining IDMS formic acid runs because the borescope was not functional between mid 1989 and mid 1993; however, the foam detector on the vapor space thermowell and the off-gas flows also did not indicate any foaming [D. Miller IDMS personal log book; personal communication with M.E. Smith]. The corresponding glasses were very oxidized (at or near the $\mathrm{Fe}^{+2} / \Sigma \mathrm{Fe}$ detection limit of 0.03 ).

The IDMS processed four batches of melter feed using the Nitric Acid Flow sheet [53]. For the first two runs (HM-4 and PX-3), HAN type PHA was used in the make up of the melter feed. These melter feeds had very high concentrations of nitrate (0.8-1.1 molar) compared to formate (0.07-0.14 molar). The remaining IDMS campaigns (PX-4, PX-5, and PX-6) were processed with the late wash flow sheet feed and contained about equal molar amounts of nitrate $(\sim 0.35$ molar) and formate ( $\sim 0.30-0.32$ molar).

The addition of excess oxidizers over reductants to high alumina containing HM sludge, as done in IDMS Campaign HM-4, thereby promoted foaming in the IDMS melter. Previous campaigns with HM sludges where the molar concentrations of reductants were greater than that of the oxidizers and/or of equivalent amount on a molar basis did not cause foaming.

The region in which a melter fugacity of $10^{-4}$ to $10^{-7}$ atmospheres can be achieved is shown as the shaded region on Figure 6. Note that the IDMS HM-4 feed that foamed clearly lies way outside the shaded region in Figure 6. During the DWPF Qualification Runs and Initial Radioactive Operations, the DWPF experienced some foaming. Analysis of the molar concentrations of formate and nitrate indicated that the DWPF was operating with high molar nitrate concentrations in excess of formate concentrations, e.g. outside the shaded region within which melter fugacities of $10^{-4}$ to $10^{-7}$ atmospheres can be achieved.

\subsection{Pacific Northwest National Laboratory}

Highly nitrated borosilicate waste glass feeds have foamed in pilot scale melter testing at PNNL $[21,23,61,62,63,64]$. In melter tests conducted by Goldman, et al. [21] at PNNL, it was found that glasses exhibiting the most tendencies for foaming were those which were made from feeds containing nitrate chemicals and lacking any reducing agent. Numerous tests have shown that foaming is diminished when reducing agents are included in the feed slurry, either in the form of processed waste (organics, oxalates) or as separate additives (formic acid, sugar), etc. A reduced glass contains less dissolved oxygen and, therefore, has a lower foaming tendency. However, even under highly reducing conditions there is an ample supply of oxygen available to produce a substantial foam layer. Goldman showed that foams generated under reducing conditions were

$1 \quad$ Late washing of the Precipitate hydrolysis 
unstable. He proposed that, under reducing conditions, proportionally more water vapor is released which destabilizes the foam [21].

\subsection{Marcoule (France)}

Highly nitrated borosilicate waste glass feeds have also foamed in French production [65] melters. Foaming due to gases being released by the high nitrate concentration of the French acid wastes caused the French to precalcine their waste to remove nitrates prior to the entry of the feed into their Joule heated melters [65].

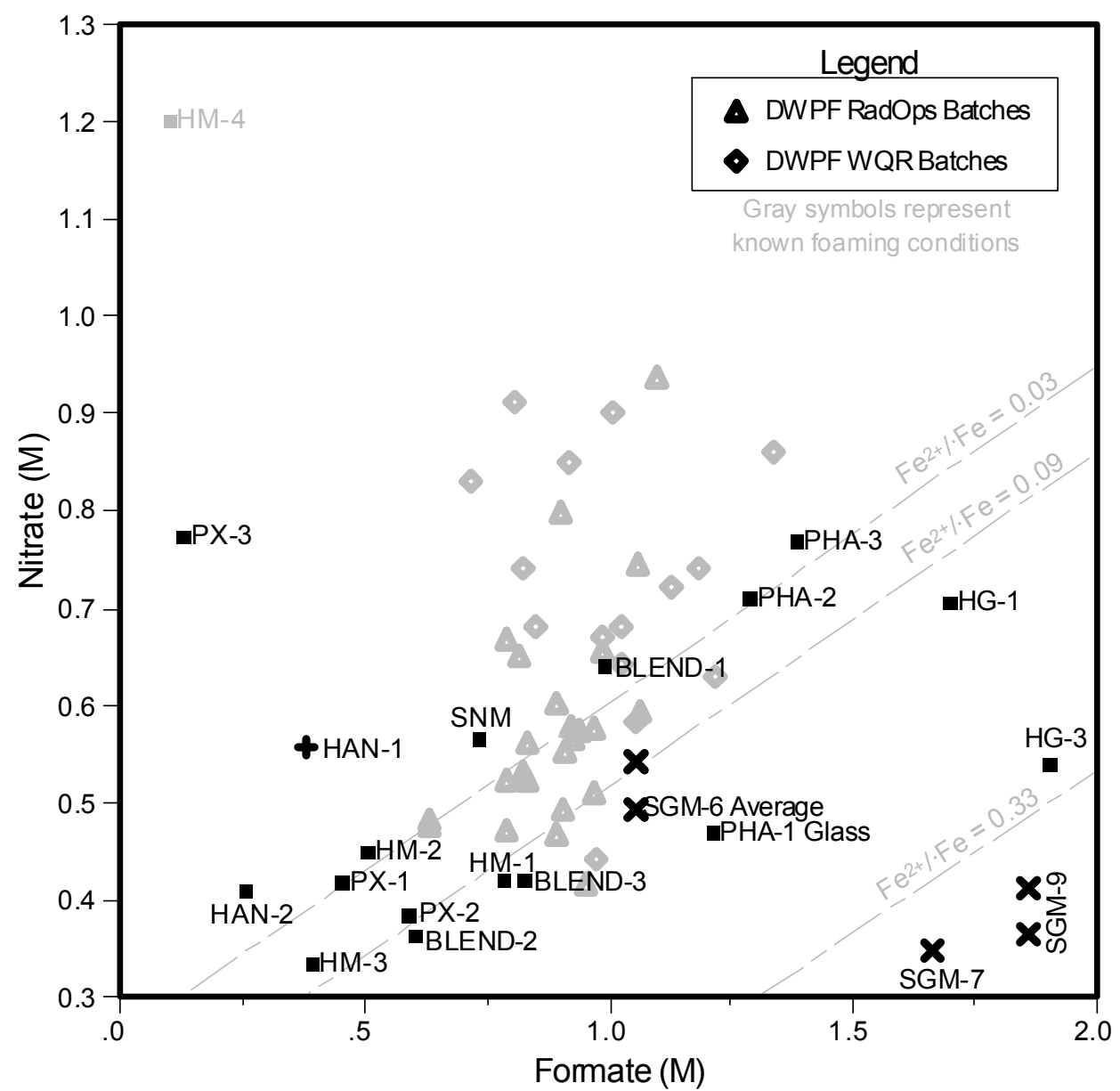

Figure 6. Concentrations of nitrate (molar) and formate (molar) processed in SGM, IDMS, and DWPF. The formate and nitrate concentrations that are acceptable to avoid foaming, e.g. $\mathrm{Fe}^{+2} / \sum \mathrm{Fe}$ values between 0.09 and 0.33 , are shaded for emphasis. These limits correspond to the limits defined by the Schreiber EMF series. Note that some melter campaigns between the $\mathrm{Fe}^{+2} / \Sigma \mathrm{Fe}$ limit of 0.09 and the analytic detection limit of 0.03 also did not report foaming events. However, use of the REDOX ratio at the detection limit for process control is not advisable and the limit of $\mathrm{Fe}^{+2} / \Sigma \mathrm{Fe}=0.09$ is conservative. Solid squares represent IDMS campaigns and crosses represent Scale Glass Melter (SGM) campaigns. 
Table 3 History of the Scale Glass Melter (SGM) and the Integrated DWPF Melter System (IDMS)

\begin{tabular}{|c|c|c|c|c|c|c|c|}
\hline $\begin{array}{c}\text { Melter } \\
\text { Campaign }\end{array}$ & Frit/Sludge/Flow sheet & $\begin{array}{c}\text { Lbs. } \\
\text { of } \\
\text { Glass } \\
\end{array}$ & Ref. & Foam & $\frac{\mathbf{F e}^{2+}}{\sum \mathbf{F e}}$ & $\begin{array}{c}\text { Formate } \\
\text { Mean } \\
(\mathrm{M})^{66} \\
\end{array}$ & $\begin{array}{l}\text { Nitrate } \\
\text { Mean } \\
(\mathrm{M})^{66}\end{array}$ \\
\hline SGM-1 & F165/Average/Sludge Only & 21,000 & 47 & No & & & \\
\hline SGM-2+3 & F200/Average/Coupled PHA & 20,700 & 47 & No & & & \\
\hline SGM-4+5 & $\begin{array}{c}\text { F168/Average/ Sludge Only; } \\
0.10 \% \text { coal }\end{array}$ & 29,300 & 48 & No & $0.52,0.40$ & & \\
\hline SGM-6+7 & $\begin{array}{c}\text { F200/Average/Coupled HAN } \\
\text { PHA; 0.11\% coal } \\
\text { F200/F168/Average/Coupled } \\
\text { HAN PHA; } 0.13 \% \text { coal } \\
\end{array}$ & 51,500 & 49 & No & $\begin{array}{c}0.05-0.16 \\
0.5-0.6\end{array}$ & $\begin{array}{l}1.057 \\
1.666\end{array}$ & $\begin{array}{l}0.545 \\
0.35\end{array}$ \\
\hline SGM-8 & 165 Black Frit & 37,000 & 50 & No & & & \\
\hline SGM-9 & $\begin{array}{c}\text { F200/Average/Coupled HAN } \\
\text { PHA + Organics }\end{array}$ & 28,551 & 51 & No & $0.4-0.45$ & 1.861 & 0.412 \\
\hline SGM-10 & $\begin{array}{c}\text { F168/Average/Coupled PHA + } \\
\text { Organics } \\
\end{array}$ & 7,623 & 51 & Scum & $\sim 0.45$ & & \\
\hline IDMS Startup & DWPF Startup Frit & 200 & 56 & No & $\mathrm{N} / \mathrm{A}$ & N/A & N/A \\
\hline IDMS Base & F165/Average/Sludge Only & 7390 & 56 & No & $\mathrm{N} / \mathrm{A}$ & $\mathrm{N} / \mathrm{A}$ & N/A \\
\hline PHA \#1,2,3 & $\begin{array}{c}\text { F202/Batch } 1 \text { Sludge/Coupled } \\
\text { HAN PHA }\end{array}$ & 15,052 & 57 & Unk. & $\begin{array}{l}0.01 \\
0.14 \\
0.13\end{array}$ & $\begin{array}{l}1.2174 \\
1.2897 \\
1.3893\end{array}$ & $\begin{array}{l}0.4694 \\
0.7128 \\
0.7673\end{array}$ \\
\hline Hg Runs & $\begin{array}{l}\text { F202/Batch 1 Sludge/Coupled } \\
\text { with PHA }\end{array}$ & 14,123 & 58 & Unk. & $\begin{array}{l}0.01 \\
0.01 \\
0.07 \\
\end{array}$ & $\begin{array}{l}1.7018 \\
1.9071 \\
\end{array}$ & $\begin{array}{l}0.7048 \\
0.5408 \\
\end{array}$ \\
\hline Blend 1 & $\begin{array}{c}\text { F202/Blend } 1 \text { Sludge with Noble } \\
\text { Metals/Coupled with PHA }\end{array}$ & 2,809 & 59 & Unk. & 0.008 & 0.9959 & 0.6392 \\
\hline Blend 2 & $\begin{array}{l}\text { F202/Blend } 2 \text { Sludge/Coupled } \\
\text { with PHA }\end{array}$ & 5,014 & 59 & Unk. & 0.023 & 0.6077 & 0.3632 \\
\hline Blend 3 & $\begin{array}{c}\text { F202/Blend } 3 \text { Sludge/Coupled } \\
\text { PHA }\end{array}$ & 1,774 & 53 & Unk. & 0.013 & 0.8274 & 0.4204 \\
\hline HM-1 & $\begin{array}{c}\text { F202/HM Sludge/Coupled with } \\
\text { PHA + NaNO3 }\end{array}$ & 2,977 & 53 & Unk. & 0.014 & 0.7906 & 0.4209 \\
\hline HM-2 & F202/HM Sludge/Coupled PHA & 2,739 & & Unk. & 0.04 & 0.5125 & 0.4489 \\
\hline HM-3 & F202/HM Sludge/Coupled PHA & 4,048 & & Unk. & 0.003 & 0.3977 & 0.3345 \\
\hline $\mathrm{PX}-2$ & $\begin{array}{c}\text { F202/Purex Sludge/Coupled } \\
\text { PHA }\end{array}$ & 3,120 & & Unk. & 0.01 & 0.5937 & 0.3836 \\
\hline PX-1 & $\begin{array}{c}\text { F202/Purex Sludge/Coupled } \\
\text { PHA }\end{array}$ & 4,073 & & Unk. & 0.01 & 0.4595 & 0.4191 \\
\hline Hanford & $\begin{array}{c}\text { Hanford Waste + Frit + Nitric } \\
\text { Acid }\end{array}$ & 7,951 & 60 & Unk. & 0.02 & $\begin{array}{l}0.3857 \\
0.2607 \\
\end{array}$ & $\begin{array}{l}0.5541 \\
0.4112 \\
\end{array}$ \\
\hline HМ-4 & $\begin{array}{c}\text { F202/HM Sludge/Nitric Acid + } \\
\text { HAN } \\
\end{array}$ & 4,355 & & $\begin{array}{l}\text { Yes } \\
{[54]}\end{array}$ & 0.024 & 0.1079 & 1.2031 \\
\hline $\mathrm{PX}-3$ & F202/Purex Sludge/CoupledHAN & 5,073 & & Unk. & 0.014 & 0.1361 & 0.7737 \\
\hline PX-4 & $\begin{array}{c}\text { F202/Purex Sludge/Nitric Acid + } \\
\text { Late Wash PHA }\end{array}$ & 4,850 & & Unk. & 0.014 & $0.368[54]$ & 0.410 [54] \\
\hline PX-5 & $\begin{array}{c}\text { F202/Purex Sludge/Nitric Acid + } \\
\text { Late Wash PHA }\end{array}$ & 4,075 & & Unk. & & & \\
\hline PX-6 & $\begin{array}{c}\text { F202/Purex Sludge/Nitric Acid + } \\
\text { Late Wash PHA }\end{array}$ & 1,943 & 67 & Unk. & & & \\
\hline
\end{tabular}


WSRC-STI-2006-00066

Revision 0

\subsection{Analyses of Gases in Foam from Pilot and Production Melters}

In the absence of nitrates, borosilicate waste glasses that were reduced with formic acid (Small Cylindrical Melter, SCM-2, and Large Slurry Fed Melter, LSFM-6) evolved foam composed primarily of $\mathrm{CO}_{2}$ and $\mathrm{O}_{2}[25,68]$ as measured by Brockway glass by gas chromatography. In more oxidized melts containing no formic acid, the primary gas evolved in the form of foam was $\mathrm{O}_{2}$ from the oxidation-reduction reactions of species other than iron [6,21,63], $\mathrm{H}_{2} \mathrm{O}$ vapor [21,63], and $\mathrm{N}_{2}$ [6]. In addition, Plodinec [69] determined that foaming due to $\mathrm{O}_{2}$ release is more likely to occur for glasses high in alkali or alkaline earth oxides whether these come from the frit or the waste. In the commercial glass industry where $\mathrm{NaNO}_{3}$ and/or $\mathrm{Na}_{2} \mathrm{CO}_{3}$ is used as a source of $\mathrm{Na}_{2} \mathrm{O}$ in borosilicate glass, the primary gasses forming reboil blisters were analyzed to contain $\mathrm{CO}_{2}$ and $\mathrm{N}_{2}[30]$.

\subsection{QUALITY ASSURANCE}

All glass melting and REDOX analyses performed at SRNL were conducted in accordance with Procedure L29-0052 Rev. 1, "Vitrification of Melter Slurries for Glass REDOX $\left(\mathrm{Fe}^{+2} / \Sigma \mathrm{Fe}\right)$ and Chemical Composition Measurement." The analysis of the sample was performed by the Process Science Analytical Laboratory (PSAL) per Procedure L29-0042, Rev 2, "Determining $\mathrm{Fe}^{+2} / \mathrm{Fe}^{+3}$ and $\mathrm{Fe}^{+2} / \Sigma \mathrm{Fe}$ using UV VIS Spectrometer".

The data generated in this study was to support Technical Task Request (TTR) HLW/DWPF/TTR-2004-0031, Rev. 1. The data were generated under the guidelines of the Technical Task and Quality Assurance Plan (TT\&QAP) WSRC-RP-2004-00881, Rev. 1 [70]. The data are recorded in laboratory notebooks WSRC-NB-2003-00034, WSRC-NB-2006-00137, and WSRC-NB-2007-00011.

\subsection{EXPERIMENTAL}

Sealed crucible testing of SB4 simulants was accomplished per Procedure L29-0052 Rev. 1 as used for previous (SB3 and historic) REDOX testing. The method outlined in the procedure involved heat treating the simulant at $1150^{\circ} \mathrm{C}$ for one hour in a crucible sealed with nepheline gel using sufficient feed to generate approximately 30 grams of glass. The glass was broken out of the crucibles and pieces of glass from the interior of the solidified glass were submitted for REDOX analysis. The $\mathrm{Fe}^{+2} / \Sigma \mathrm{Fe}$ analysis was performed by Procedure L29-0042, Rev 2 which is the analysis developed by Baumann [71 ].

The SB4 simulants used in the testing were generated during various SB4 flowsheet and melt rate studies. The simulants were prepared as metal hydroxide slurries based on the composition estimates for SB4. The SB4 composition estimates had been updated as operational issues had changed the makeup of the batch, therefore the compositional basis varied due the testing (see Table 4). The simulants were processed through a simulated DWPF Chemical Process Cell (CPC) cycle using varied processing parameters. The run numbers represent the unique run numbers assigned to each of the SRAT/SME batches performed during simulated CPC processing $[72,73,74,75]$. The frit and target waste loadings are shown for the SME products tested (Table 4). The SRAT runs were combined with Frit 418 at 35\% waste loadings for most 
tests [76], but selected tests were performed with a variety of different frits to improve viscosity and melt rate while minimizing the potential for nepheline crystallization (as discussed in the next section).

The preliminary SB4 REDOX results indicated that all feeds were fully oxidized, including a formic acid only run (SB4-34). Tests were conducted to evaluate various alternatives to formic acid to provide control of REDOX for SB4 [77]. The additives selected (sugar, coal, and oxalate) were compounds already included in the EE REDOX prediction calculation to allow comparisons between predicted values and the measured values. In addition, additional antifoam additions were tested because antifoam is a reductant already utilized in small quantities in the DWPF process. Finally, a second formic acid addition was tested using SB4-41 feeds because additional formic acid after the SME cycle has previously been utilized during DWPF processing to control process rheology.

The addition amounts for sugar, coal, and oxalate were based on the amount of each reductant required to react completely with all the nitrate present in the feed to reduce the nitrate to nitrogen per the EE REDOX model. This amount was then halved and then quartered to generate a series of reductant concentrations. Two forms of oxalate were used: calcium oxalate and ferrous oxalate to determine if increasing the iron content and/or adding $\mathrm{Fe}^{+2}$ to the process would be helpful from either a REDOX or viscosity perspective. Antifoam additions were based on engineering judgment, while the second formic acid additions were based on the amounts added during previous DWPF utilization of formic acid as a rheological modifier ( 50 gallons of formic acid per SME batch). All tests of alternate reductants were performed on simulant from SB4-41 mixed with Frit 418 at 35\% waste loading. A baseline sample with no reductant was performed using Frit 418 as well as a baseline with Frit 425.

Results of the CPC tests and the alternate reductant tests were compared to the DWPF EE REDOX model database [15]. The ranges of all components in the EE REDOX model to the ranges tested with SB4 simulant SRAT products were compared. In addition, data generated with additional amounts of sugar, coal, and oxalate were compared to the DWPF EE REDOX model to verify that the electron equivalents terms for these species were correct.

The feeds tested were prepared at different acid stoichiometries for different purposes. Two different SB4 simulants were used, a precursor simulant and a Spintek simulant. Four liter flowsheet runs were made with both simulants as indicated in Table 4. Two different sludge compositions for SB4 were tested and the details are given elsewhere [72,73,75,78]. Acid stoichiometry ranged from $130-170 \%$. The stoichiometric amount was calculated as recommended by Hsu [14] using the amounts of mercury, manganese, nitrite, carbonate, and hydroxide (as determined by acid-base titration) in the SRAT feed. 
Table 4. Sludge Batch 4 Feeds Tested for REDOX

\begin{tabular}{|c|c|c|c|c|c|c|c|}
\hline Sample ID & Frit & $\begin{array}{c}\text { Target } \\
\text { Waste } \\
\text { Loading }\end{array}$ & $\begin{array}{c}\text { Fe/Al on } \\
\text { vitrified } \\
\text { wt\% basis }\end{array}$ & $\begin{array}{c}\text { Mn/Al on } \\
\text { vitrified } \\
\text { wt\% basis }\end{array}$ & $\begin{array}{c}\text { Acid } \\
\text { Stoichio- } \\
\text { metry (\%) }\end{array}$ & Type of Simulant/Sludge & Ref. \\
\hline \multicolumn{8}{|c|}{ 4L Flowsheet Test Runs } \\
\hline SB4-10 & 418 & 35 & 1.81 & 0.48 & 160 & Precursor & 72 \\
\hline SB4-11 & 418 & 35 & 1.63 & 0.45 & 160 & Precursor & 72 \\
\hline SB4-19 & 418 & 35 & 0.95 & 0.28 & 130 & Spintek & 73 \\
\hline SB4-20 & 418 & 35 & 0.97 & 0.30 & 170 & Spintek & 73 \\
\hline $\begin{array}{l}\text { SB4-34 (Formic } \\
\text { Acid Only) }\end{array}$ & $\begin{array}{c}418,503, \\
\text { p2-2 }\end{array}$ & 35 & $0.95-1.33^{\ddagger}$ & 0.23 & 150 & Precursor/1.67M Na blended @40” & 75 \\
\hline SB4-61 & 503 & 35 & 1.36 & 0.31 & 130 & SB4-15CT6 (Spintek/Precursor Blend)* & 78 \\
\hline SB4-62 & 503 & 35 & 1.34 & 0.31 & 150 & SB4-15CT6 (Spintek/Precursor Blend)* & 78 \\
\hline SB4-63 & 503 & 35 & 1.30 & 0.29 & 160 & SB4-15CT6 (Spintek/Precursor Blend)* & 78 \\
\hline SB4-64 & 503 & 35 & 1.33 & 0.28 & 170 & SB4-15CT6 (Spintek/Precursor Blend)* & 78 \\
\hline \multicolumn{8}{|c|}{ 22L SRAT/SME Tests for Slurry-fed Melt Rate Furnace (SMRF) } \\
\hline SB4-21/22 & 320 & 43 & 1.16 & 0.30 & 130 & Precursor/1.67M Na blended @40" & 17,74 \\
\hline SB4-23/24 & 418 & 43 & 1.26 & 0.34 & 130 & Precursor/1.67M Na blended @40" & 17,74 \\
\hline SB4-25/26 & 320 & 35 & 1.12 & 0.30 & 130 & Precursor/1.67M Na blended @40” & 17,74 \\
\hline SB4-27/28 & 418 & 35 & 1.16 & 0.31 & 130 & Precursor/1.67M Na blended @40" & 17,74 \\
\hline SB4-49/50 & 418 & 35 & 1.38 & 0.29 & 150 & SB4-15CT6 (Spintek/Precursor Blend)* & 75 \\
\hline SB4-51/52 & 425 & 35 & 1.35 & 0.30 & 150 & SB4-15CT6 (Spintek/Precursor Blend)* & 75 \\
\hline \multicolumn{8}{|c|}{ 22L SRAT Runs for Melt Rate Furnace (MRF) } \\
\hline SB4-32 & $\begin{array}{c}418,503, \\
\text { p2-2 }\end{array}$ & 35 & $0.90-1.26^{\ddagger}$ & 0.25 & 130 & Spintek & 75 \\
\hline SB4-41 & $418, \mathrm{p} 2-2$ & 35 & $0.92-1.28^{*}$ & 0.22 & 150 & Spintek & 75 \\
\hline
\end{tabular}

${ }^{\ddagger} \mathrm{Fe} / \mathrm{Al}$ ratio varies as frits contained variable amounts of $\mathrm{Fe}$ 
WSRC-STI-2006-00066

Revision 0

\subsection{RESULTS AND DISCUSSION}

\subsection{REDOX Model Ranges: SB3 vs. SB4}

The SB4 REDOX values (expressed as $\mathrm{Fe}^{+2} / \Sigma \mathrm{Fe}$ ) and the molar formate, molar nitrate and molar manganese values were compared to the SB3 REDOX and historic data used in the development of the EE REDOX model in 2003 [15]. Since there was no coal and no oxalate in SB4, a comparison of these components was not included. The waste loadings processed during SB4 REDOX testing were $35 \mathrm{wt} \%$ and $43 \mathrm{wt} \%$. The majority of the SB4 REDOX tests were at a 35 $\mathrm{wt} \%$ target waste loading which was the same as the maximum waste loading tested during SB3 REDOX model development (Figure 7).

The manganese concentration $(\mathrm{mg} / \mathrm{kg})$ on a slurry basis in the SRAT products used for SB4 REDOX testing overlapped the range of manganese tested during SB3 REDOX development but the span of the manganese concentrations was larger than that used during the historic REDOX model development (Figure 7). Data on analyzed SRAT products on a calcine oxide basis was available for SB3 and SB4 SRAT products. A comparison of the MnO in the SRAT product on a $\mathrm{wt} \%$ calcine basis was considerably higher for SB4 than the range tested during SB3 (Figure 8). Moreover, when the Mn concentration in $\mathrm{mg} / \mathrm{kg}$ is converted to $\mathrm{Mn}$ in $\mathrm{mol} / \mathrm{kg}$ and normalized to $45 \mathrm{wt} \%$ solids in the frit/SRAT product mixture, the units needed for the EE REDOX model, it becomes apparent that the higher waste loadings coupled with the higher Mn in the SB4 testing, causes the Mn in mol $/ \mathrm{kg}$ of SME product to be much higher than that tested during SB3 (Figure 8). This translates into much higher $\mathrm{MnO}$ in the final glass product, i.e., up to $3 \mathrm{wt} \%$ in SB4 versus a maximum of $\sim 2 \mathrm{wt} \%$ in SB3 (Figure 9), although up to $2.83 \mathrm{wt} \%$ $\mathrm{MnO}$ in the final glass was processed during SGM-9 and SGM-10 but these were very reducing melter campaigns. Crucible tests from these two campaigns as well as from DWPF Qualification Run Batch 1 form the historic REDOX database.

In addition, the SB4 SRAT products had considerably more soluble manganese (expressed as \% $\mathrm{Mn}$ ) than SB3 SRAT products as shown in Figure 10. Soluble Mn data was not available for the historic data. The highest soluble Mn in the SB4 series of REDOX tests was experienced with SB4-63 and SB4-64. The next highest soluble Mn was experienced with SB-11 followed by SB4-62 and SB4-20. Run SB4-63 was 160\% stoichiometric acid, while SB4-64 was 170\% stoichiometric acid in the SRAT (Table 4). Likewise, SB4-11 was 160\%, SB4-62 was 150\%, and SB4-20 was 170\% stoichiometric acid (Table 4). Thus a plot of stoichiometric SRAT acid addition vs. soluble Mn for SB4 and SB3 indicates a parabolic dependence of soluble Mn with stoichiometric acid used during SRAT processing (Figure 11) and a linear dependence with final SRAT $\mathrm{pH}$ (Figure 11). The final SRAT $\mathrm{pH}$ refers to the $\mathrm{pH}$ measured after the SRAT product cools to room temperature.

The ranges of formate and nitrate (mol/ $\mathrm{kg}$ normalized to $45 \mathrm{wt} \%$ solids - the units used in the EE REDOX model) in the frit/SRAT mixtures for SB3 and SB4 are shown in Figure 12. The formate and nitrate concentrations tested during SB3 and SB4 REDOX modeling were comparable leaving manganese as the only SB4 REDOX species that was outside the EE REDOX model range tested during SB3 and historic REDOX modeling. 

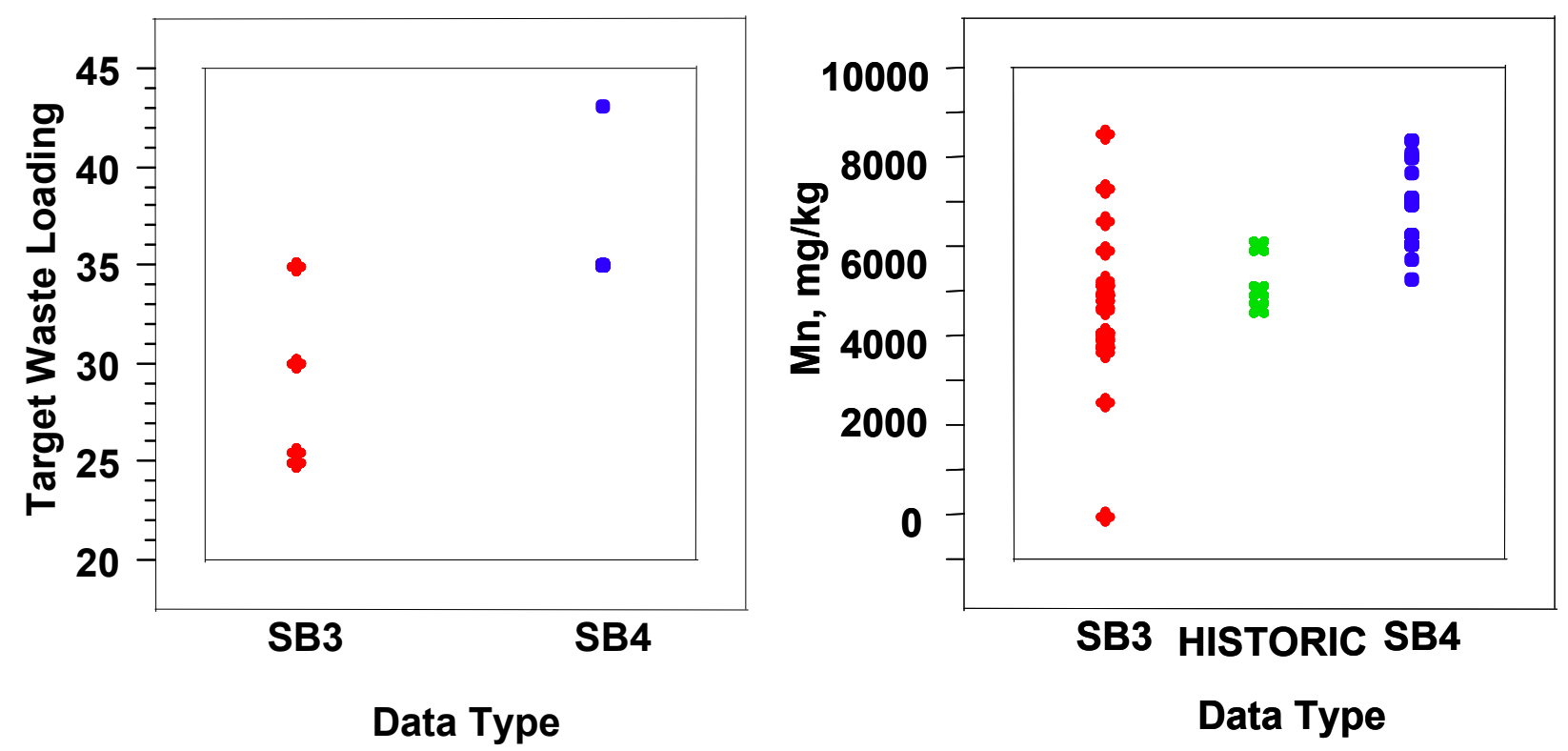

Figure 7. Comparison of target waste loading and Mn concentration on a slurry basis in the Sludge Receipt Adjustment Tank (SRAT) products tested during REDOX modeling. The "+" values (red) indicate SB3 REDOX data, the solid circles (blue) indicate SB4 REDOX data, and the " $x$ " values (green) indicate HISTORIC REDOX model data (if available) from crucibles.
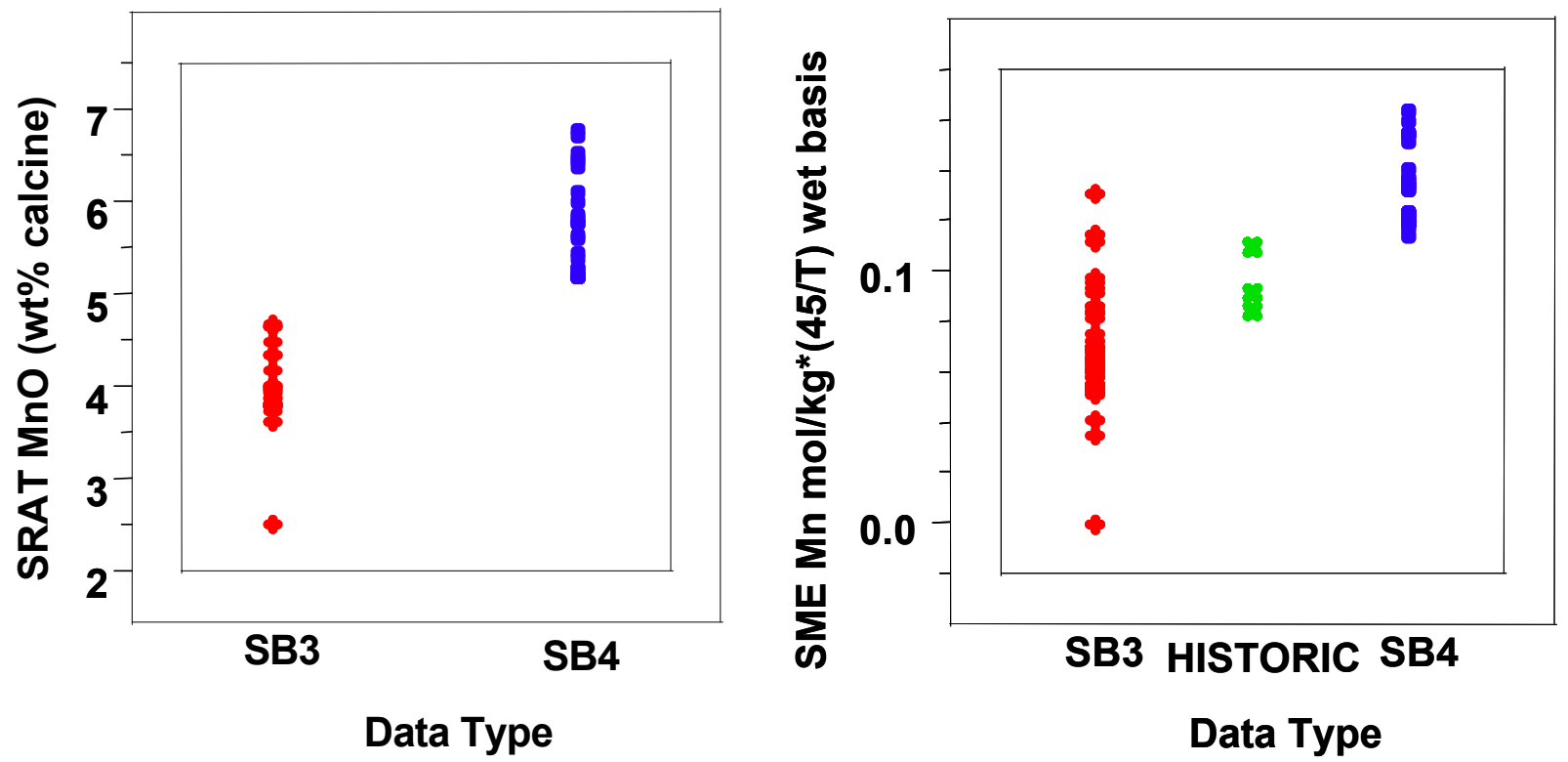

Figure 8. Comparison of the Mn SRAT concentration on a dry calcine oxide basis and in the SME products tested during REDOX modeling. The "+" values (red) indicate SB3 REDOX data, the solid circles (blue) indicate SB4 REDOX data, and the " $x$ " values (green) indicate HISTORIC REDOX model data (if available) from crucibles. 


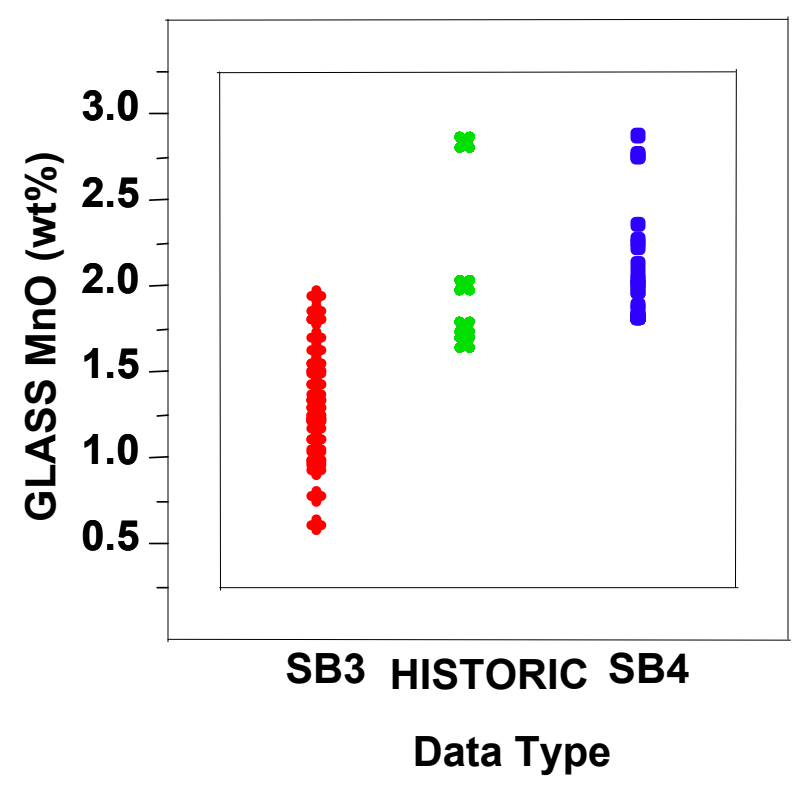

Figure 9. Manganese in final glass product for SB3 vs. SB4. The "+" values (red) indicate SB3 REDOX data, the solid circles (blue) indicate SB4 REDOX data, and the " $x$ " values (green) indicate HISTORIC REDOX model data (if available) from crucibles.

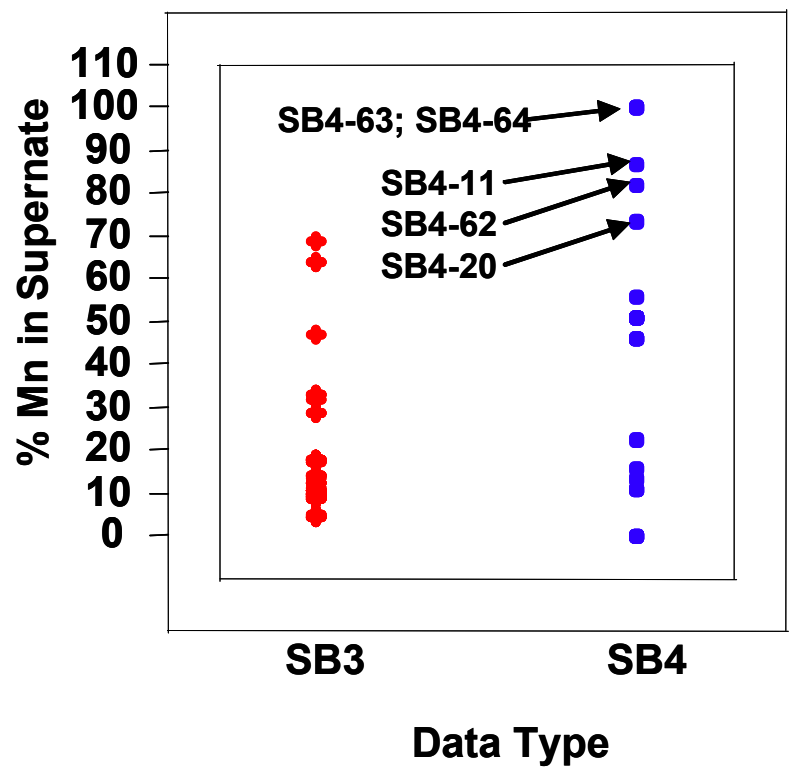

Figure 10. Soluble manganese in SB4 vs. SB3 SRAT supernates. 

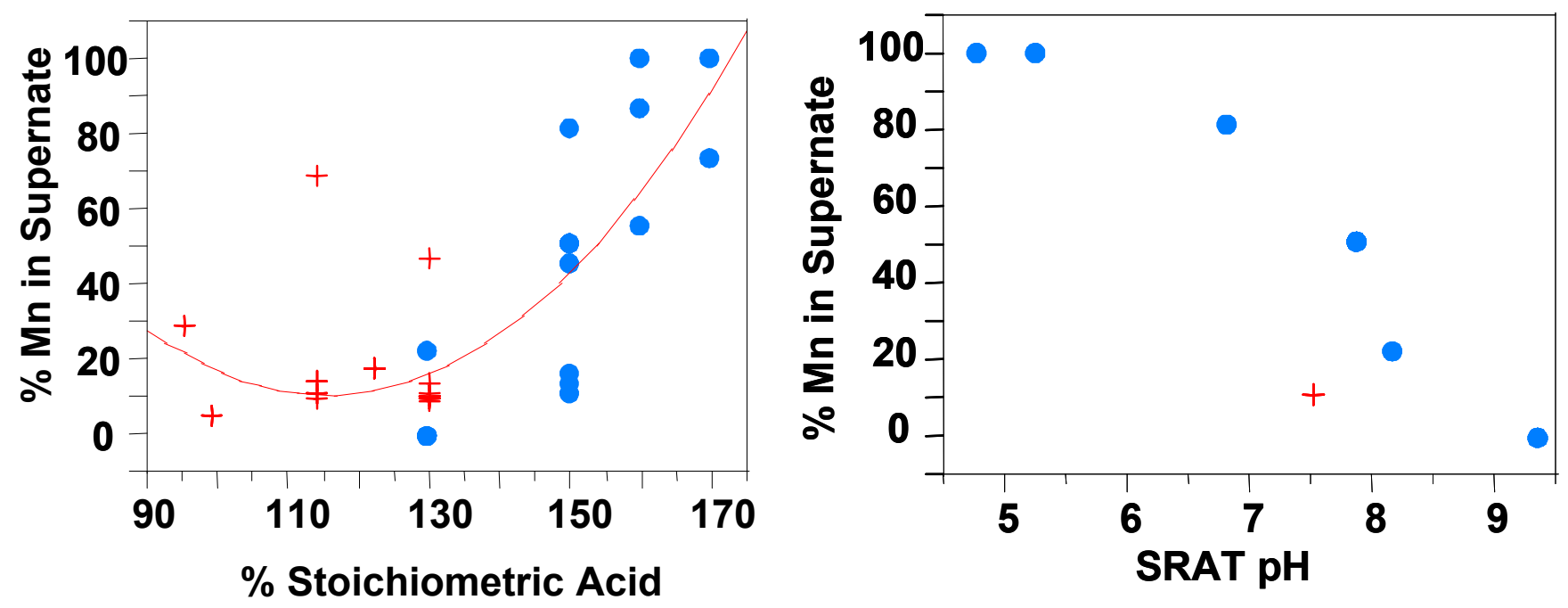

Figure 11. The relation of soluble manganese to stoichiometric acid concentrations and $\mathrm{pH}$ in the SRAT for SB3 (+) and SB4 (•).
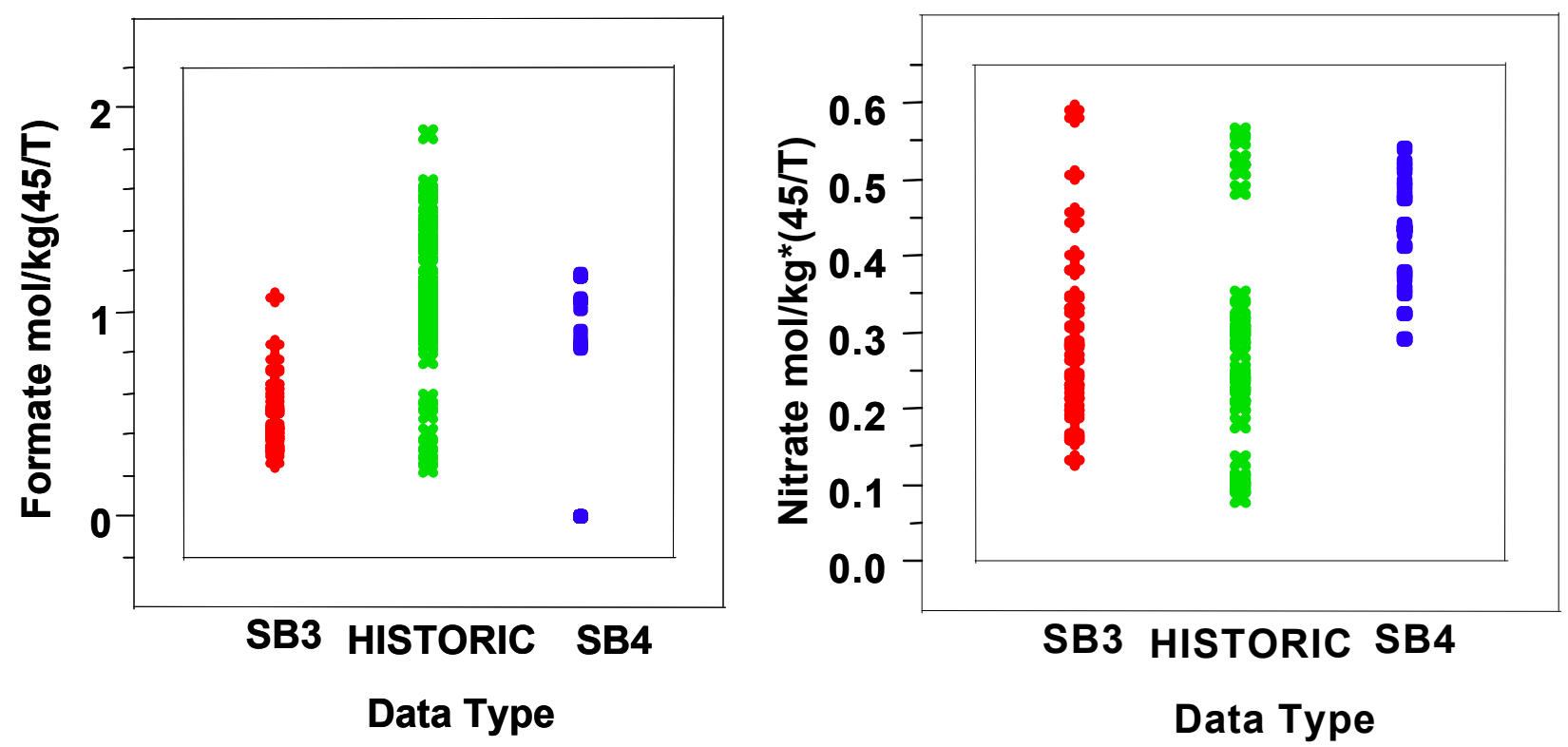

Figure 12. Comparison of the formate and nitrate in the SME products tested during REDOX modeling. The "+" values (red) indicate SB3 REDOX data, the solid circles (blue) indicate SB4 REDOX data, and the " $x$ " values (green) indicate HISTORIC REDOX model data (if available) from crucibles. 


\subsection{Glass Composition Ranges: SB3 vs. SB4}

Since the only foaming events associated with pilot scale (Section 3.1) or melt rate testing [17] at SRS were associated with HM high alumina containing sludges and since it was shown by Plodinec [69] that foaming due to $\mathrm{O}_{2}$ release is more likely to occur for glasses high in alkali or alkaline earth oxides whether these come from the frit or the waste, it is significant to examine some of the differences in the waste and glass compositions. The HM waste that dominates SB4 chemistry is high in $\mathrm{Al}_{2} \mathrm{O}_{3}$ and low in $\mathrm{Fe}_{2} \mathrm{O}_{3}$ compared to $\mathrm{SB} 3$ (Figure 13). The $\mathrm{Al}_{2} \mathrm{O}_{3}$ and $\mathrm{MnO}$ (compare Figure 13 to Figure 9) are collinear in HM sludges because the HM wastes had a higher activity and higher Al content than the Purex wastes. A manangese dioxide precipitation strike was used in the head end to remove fission products like $\mathrm{Zr}$ and $\mathrm{Nb}$ by sorption if the beta/gamma activity of the wastes were above certain limits. Thus more Mn was used when the activity was higher and this coincided with processing of higher activity HM fuel, an enriched uranium $\left(\mathrm{U}^{235}\right)$-aluminum alloy that was clad in aluminum and the entire assembly dissolved in nitric acid without a separate decladding step as done in Purex processing [19].

The total alkali in the SB4 glasses tested from all sources (waste and frit) compared to those examined in SB3 testing are shown in Figure 14. The range of total alkali tested during SB4 was not as wide as the range tested during SB3. Higher alkali was achievable with SB3 because this was a Purex type sludge and it contained an excess of refractory oxides of $\mathrm{Np}$ and $\mathrm{Pu}$. High alkali containing frits when combined with high alumina containing HM wastes can form nepheline as a crystalline product during canister cooling and nepheline formation has been determined to be detrimental to DWPF glass durability [80]. Therefore, the $\mathrm{B}_{2} \mathrm{O}_{3}$ content of the SB4 glasses was increased to above that tested in SB3 to flux the very viscous SB4 high alumina containing glasses (Figure 14) and a high $\mathrm{B}_{2} \mathrm{O}_{3}$ frit (Frit 503) was initially recommended for SB4 processing in DWPF [81]. This recommendation may change depending on the final alkali content of SB4. Increasing the $\mathrm{B}_{2} \mathrm{O}_{3}$ content of the glass allows the $\mathrm{Na}_{2} \mathrm{O}$ to preferentially bond to the $\mathrm{B}_{2} \mathrm{O}_{3}$, forming $\mathrm{NaBO}_{2}$ groups decreasing the number of available $\mathrm{NaAlO}_{2}$ nepheline forming groups [82].

Higher alkali glasses are known to stabilize oxidized alkali-ferric iron $\left(\mathrm{NaFeO}_{2}\right)$ [83] and alkalimanganic $\left(\mathrm{NaMnO}_{2}\right)$ [84] complexes in glass over their reduced counterparts. In addition, Schreiber, et. al. found small differences in the REDOX of Frit 165 (lower alkali) and Frit 131 (higher alkali) [85]. Waff [83] also demonstrated that at constant oxygen fugacity, increasing the total iron of a glass increased the amount of ferric iron. Stabilization of alkali-ferric iron and alkali-manganic complexes in alkali-rich melts was not found to be statistically significant during the SB3 REDOX modeling $[15,16]$ and this effect was not observed during SB4 REDOX testing likely because the SB4 glasses had a reduced range of molar alkali compared to the glasses tested during SB3 (Figure 14). As noted in SB3 REDOX testing [15,16], there is a strong correlation of measured REDOX with the total molar concentration of $\mathrm{MnO}$ in the glass (Figure 15) and a similar correlation of measured REDOX with the total molar concentration of $\mathrm{Fe}_{2} \mathrm{O}_{3}$ in the glass as suggested by Waff [83]. The slope of the measured REDOX ratio vs molar $\mathrm{Fe}_{2} \mathrm{O}_{3}$ in the glass is shallower than the slope of the measured REDOX ratio vs molar $\mathrm{MnO}$ in the glass. The dependence of the REDOX on the molar concentration of $\mathrm{MnO}$ in a glass during SB3 testing was one of the major reasons that a manganese term had been added to the DWPF REDOX EE model $[15,16]$. 

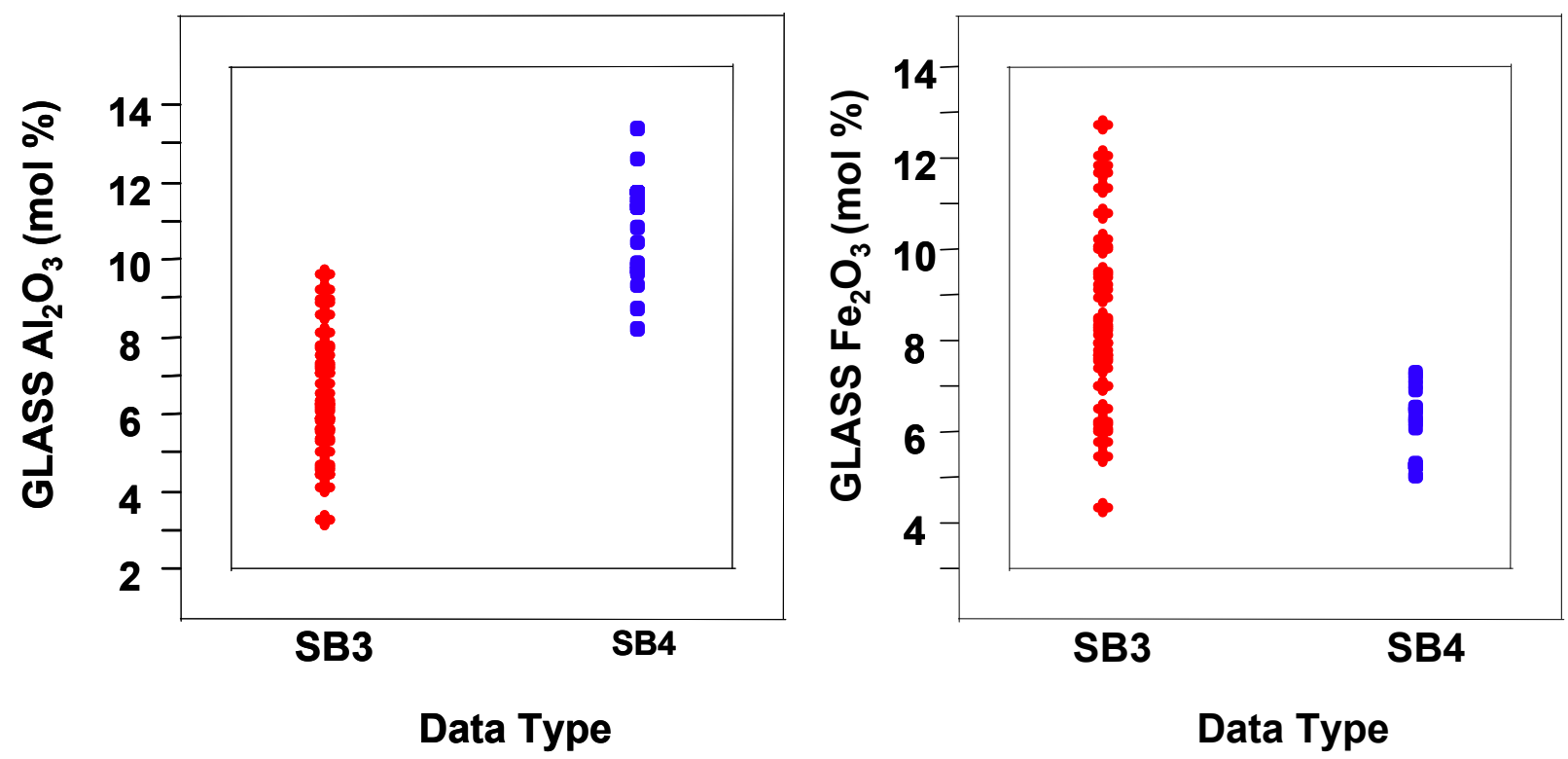

Figure 13. Comparison of alumina and iron oxides in SB3 vs. SB4 glasses used for REDOX testing. The "+" values (red) indicate SB3 REDOX data and the solid circles (blue) indicate SB4 REDOX data. HISTORIC REDOX model data was not available.

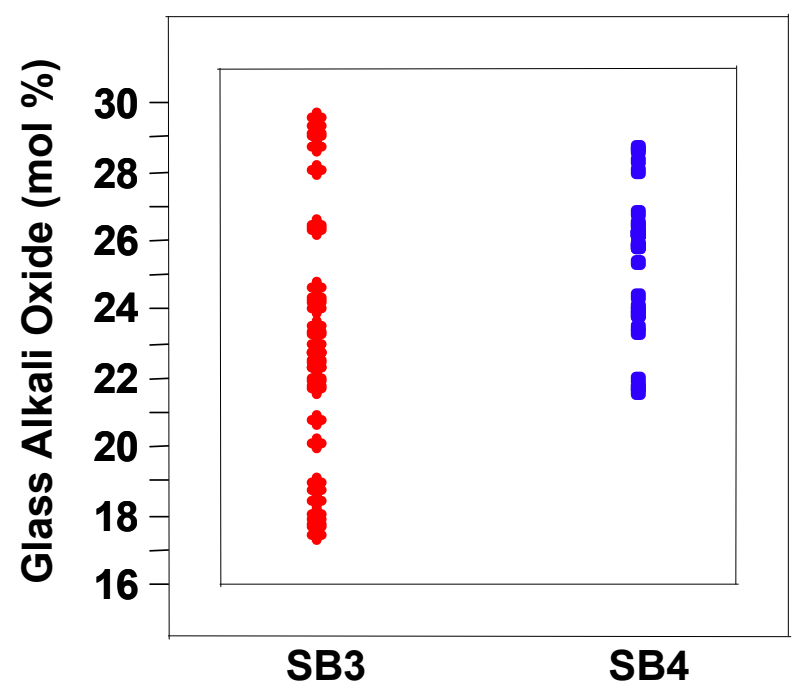

Data Type

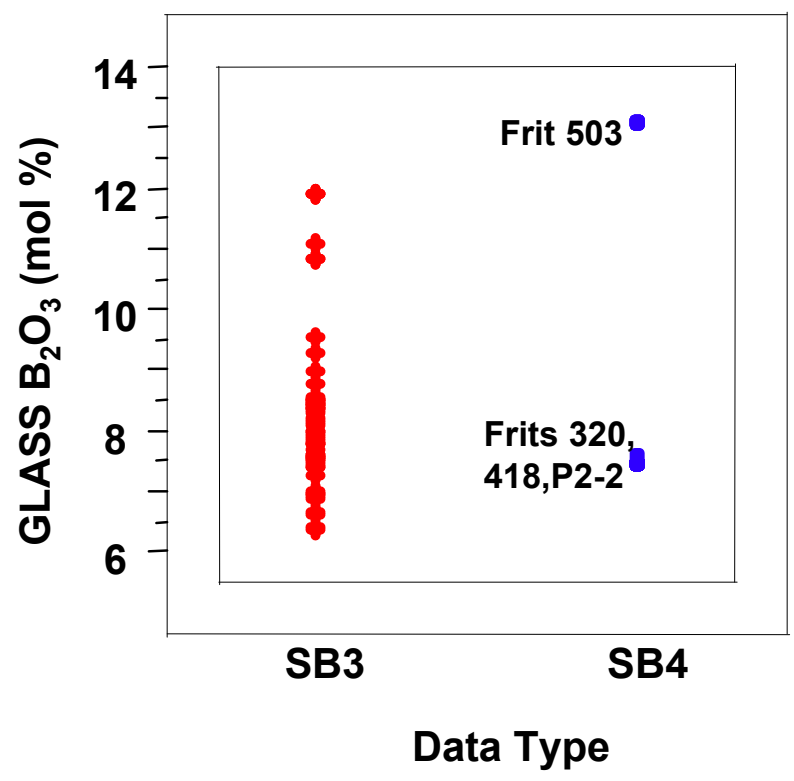

Figure 14. Comparison of total alkali (frit and sludge $\mathrm{Na}_{2} \mathrm{O}, \mathrm{Li}_{2} \mathrm{O}$, and $\mathrm{K}_{2} \mathrm{O}$ ) and boron oxides in the glasses used for REDOX testing. Since the $\mathrm{B}_{2} \mathrm{O}_{3}$ comes from the frit only, the frit designations are given on the figure. The "+" values (red) indicate SB3 REDOX data and the solid circles (blue) indicate SB4 REDOX data. HISTORIC REDOX model data was not available. 

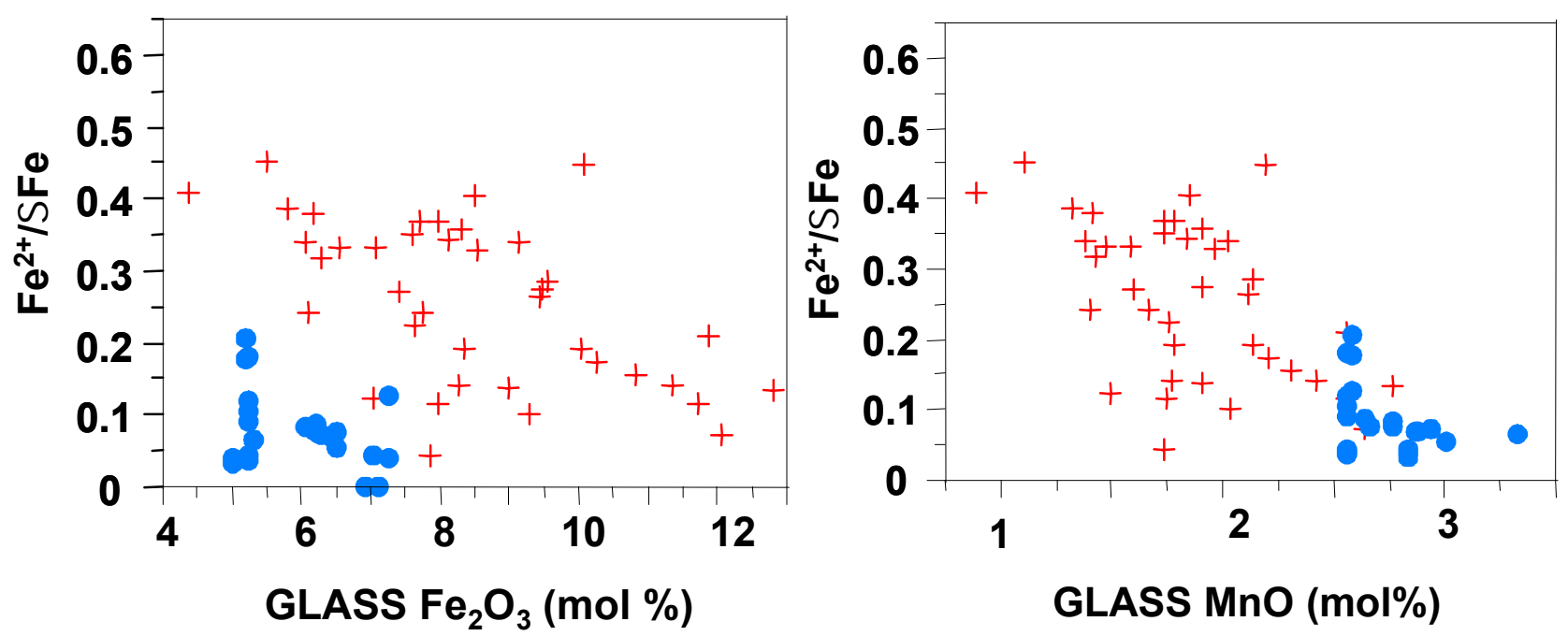

Figure 15. Relation of manganese and iron oxide in the glasses REDOX tested in SB3 $(+)$ and SB4 $(\bullet)$ to the measured REDOX ratio.

\subsection{Role of Glass Homogeneity and Variability in REDOX Measurements and Modeling Database}

The development of REDOX modeling data for SB4 included various SRAT and SME runs at various acid stoichiometries between $130-170 \%$ that used alternate reductants such as coal, sugar, Ca-oxalate, Fe-oxalate, and DWPF antifoam, as well as various frits, as discussed in Section 5.0. The same criteria were applied to SB4 REDOX model data as to the historic [12] and SB3 model data [15] development for consistency:

- Glass must be produced from properly formated melter feed material,

- Vitrified material must be visibly black and homogeneous; that is, it must contain no brown discoloration due to metallic copper and/or no crystalline or other metallic material as these species make both reliable REDOX and composition measurements impossible,

- REDOX ratio (i.e., $\mathrm{Fe}^{2+} / \Sigma \mathrm{Fe}$ ) must be measured using the Baumann technique [71] and must be greater than or equal to the detection limit of 0.03 ,

- REDOX and feed chemistry (from which REDOX is predicted) must both be available for the sample,

- Measured or as-made total solids information must be available, and

- If sample was made in a crucible, the seal must be continuous and in tact per procedure L29-0052, Rev.1.

The REDOX data generated from SB4 testing, as well as the historic and SB3 model data from References 12 and 15 which met the above criteria, are summarized in Table 5. The data generated on SB4 testing that was not used in REDOX modeling is shaded in Table 5. Samples SB4-32, SB4 Precursor, SB4-10 and SB4-11 were not used as the REDOX values measured 
were at or below the detection limit of 0.03 . Likewise the SMRF runs made from SRAT runs designated SB4-21/22, SB4-25/26, and SB4-27/28 had REDOX values of 0.0, i.e., below the 0.03 detection limit and this data was not used for modeling or validation.

Many of the SB4 glasses like SB4-32, SB4-49 and SB4-51 were highly inhomogeneous. Many swirls of oxidized iron (Figure 16) made measurement of the total iron value in SB4 samples very difficult and impacted the reproducibility of the total Fe number. Therefore, 4 replicate REDOX values were measured on each sample and the sum of the $\mathrm{Fe}^{+2}$ values was divided by the sum of the four total iron values to minimize error in the modeling dataset as these glasses were used for REDOX modeling even though they were inhomogeneous. This exception was made because there were only 19 glasses in the SB4 database and it was thought that the statistical averaging of the four REDOX replicates would smooth out errors caused by the glass inhomogeneities. Note that the SB4-34 glass in Figure 16 is more homogeneous than SB4-32, SB4-49 and SB4-51 but none of the SB4 glasses are as homogeneous as the SB2/3 glasses (Figure 17).

Because so many of the early SB4 test results exhibited foaming [17] and the measured REDOX was always below the detection limit even when the REDOX target was $\geq 0.2$, additional tests were conducted to evaluate various alternatives to formic acid to provide control of REDOX for SB4 as discussed in Section 5.0. The additives selected (sugar, coal, and oxalate) were compounds already included in the REDOX prediction calculation to allow comparisons between predicted values and the measured values. Calcium oxalate and ferrous oxalate were the two forms of oxalate used to determine if increasing the total iron content and/or adding $\mathrm{Fe}^{+2}$ to the process would be helpful. The reductants were doped in after SRAT processing but before being dried to "peanut butter" consistency and remixed for REDOX testing. Many of the samples made with the alternate reductants had metallic inclusions and were not homogeneous as shown in Figure 18. The inhomogeneity was likely because the glasses were doped with the additional REDOX species after SRAT processing instead of being included during SRAT processing.

The full sugar, half sugar, full coal, half coal, quarter coal, full Fe oxalate, all the Ca oxalates either had inclusions or were inhomogeneous (Figure 18) and not used in REDOX modeling. The sugar, coal, and oxalate glasses that were homogeneous were used in REDOX modeling to verify the terms in the EE model for these species. The antifoam samples were excluded from REDOX modeling as an electron transfer term for the antifoam has not yet been determined.

The alternate reductant studies were used to validate the oxalate, formic acid, nitric acid, and sugar terms in the EE REDOX model, but the solid reductant test results were not used during development of a new manganese term because these glasses were so inhomogeneous. Formate and nitrate data was not available for SB4-48 and this sample was not used for further REDOX modeling.

For REDOX modeling from all sources, there were 67 historic data points, 53 SB3 data points, and 19 SB4 data points for a total of 139 REDOX data points. It should be noted that the modeling data did not include the validation data from the DWPF melter (SME 224 [86]), the SB2/3 SMRF campaigns with Frit 202, the SB4 SMRF campaigns with REDOX values $>0.03$ 
[87], nor the simulated feeds processed in the SRNL minimelter (MM) in 786-A (as discussed in References 15 and 16 and shown in Figure 5). These data were kept as validation data (Table 5).

While the historical REDOX database was developed by doping SME products with additional formic acid and nitric acid, the SB3 and SB4 databases were developed on formic and nitric acid concentrations that had been refluxed through a SRAT cycle. The SRAT concentration data is then adjusted for the measured amounts of frit that is added to a crucible before REDOX testing to adjust for the $\mathrm{wt} \%$ solids in the simulated SME feed in the crucible test. This methodology was necessitated to be able to compare various tests, i.e., crucibles vs. minimelter vs. DWPF, some of which were based on SRAT analyses and some of which were based on SME analyses.

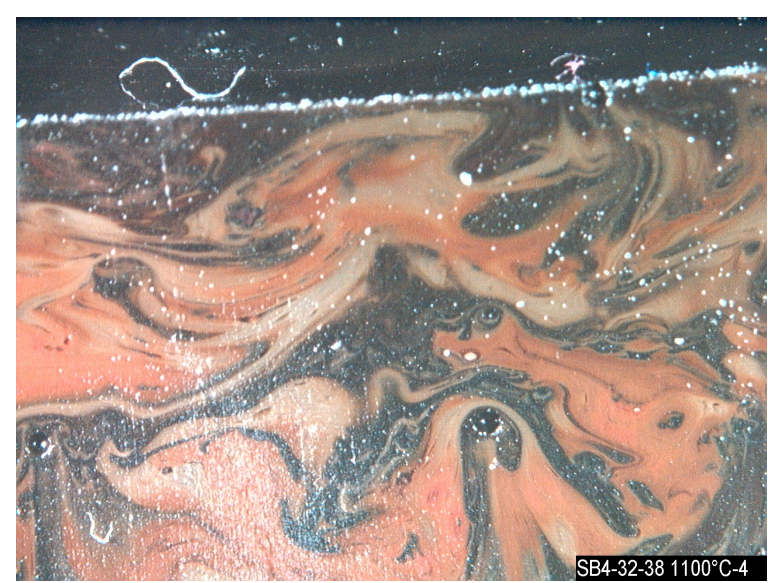

SB4-32 at 35 wt $\%$ Waste Loading - Frit 418

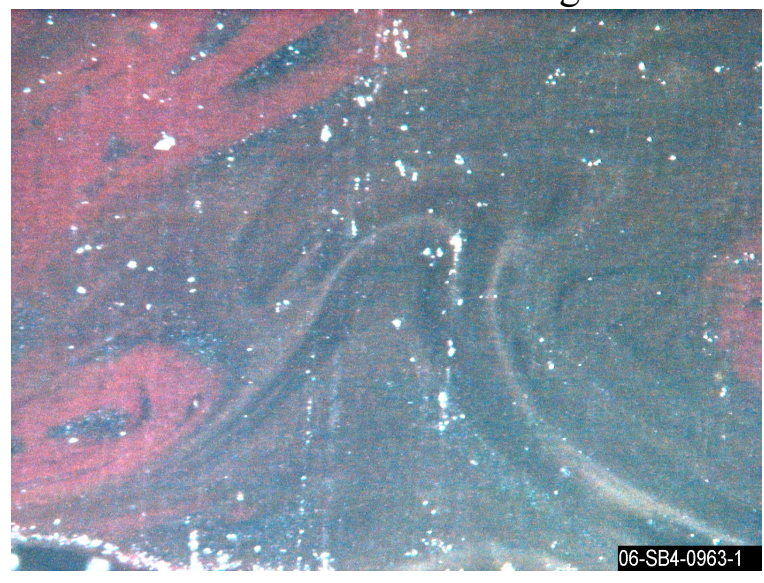

SB4-51 at 35\% Waste Loading - Frit 425

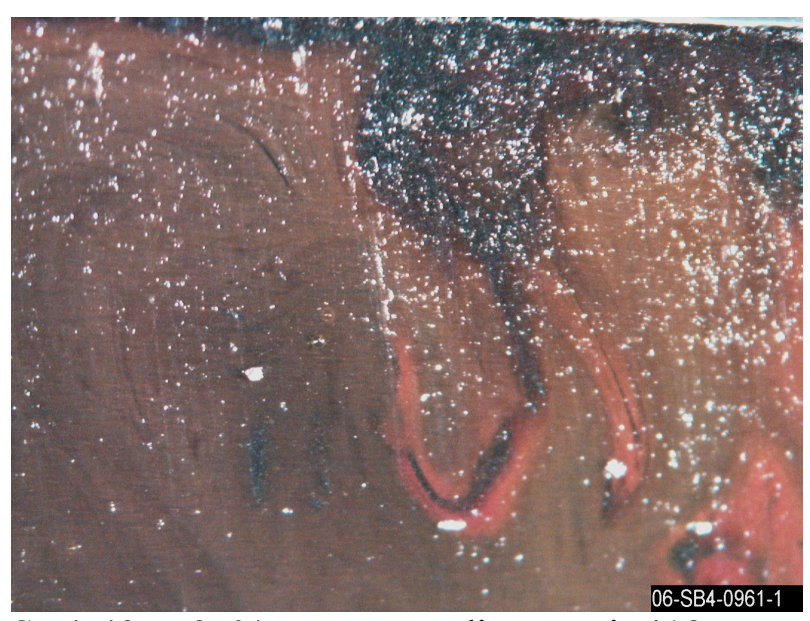

SB4-49 at 35\% Waste Loading - Frit 418

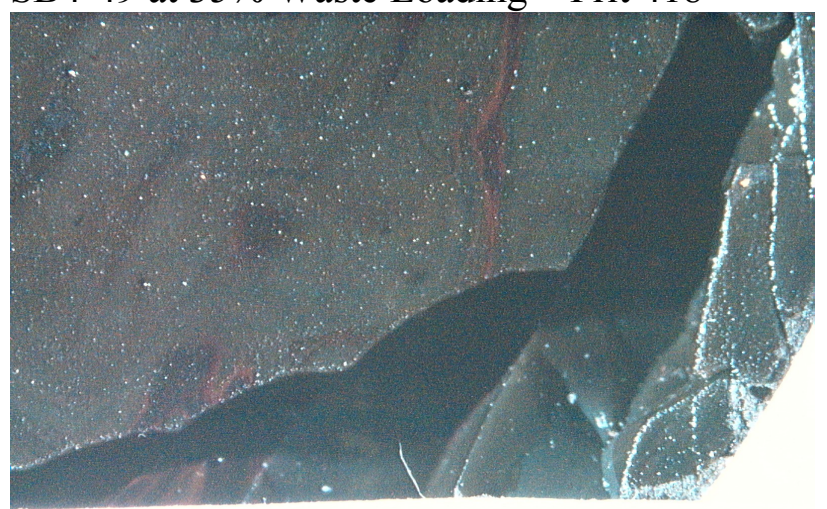

SB4-34-35-R2-1100 $\mathrm{C}-10$. tif

SB4-34 at 35\% Waste Loading Formic Acid Only

Figure 16. Inhomogeneities in SB4 glasses made with formic acid and nitric acid additions only. 
WSRC-STI-2006-00066

Revision 0

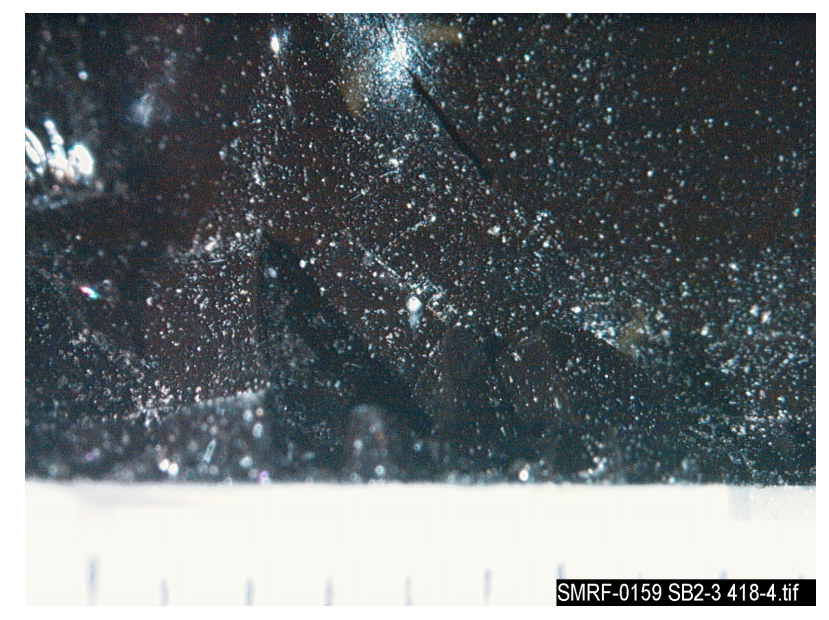

Figure 17. Homogeneous SB2/3 glass made with formic acid and nitric acid additions only. 


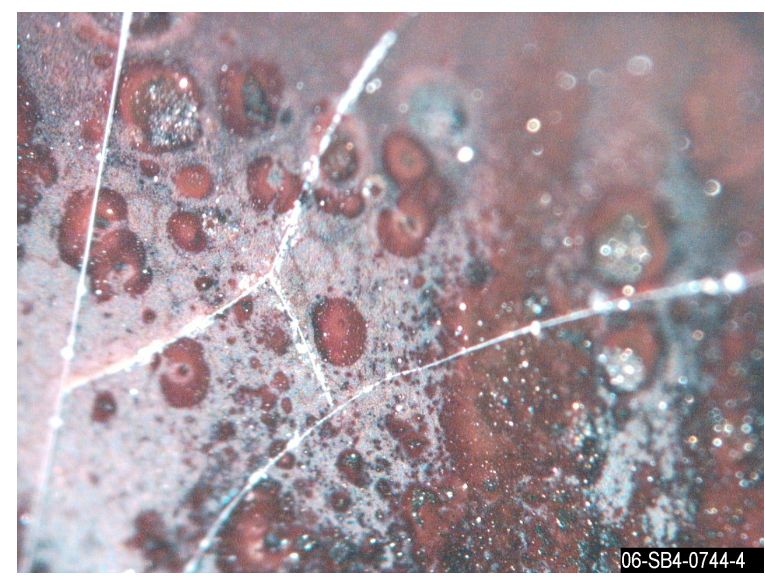

Full amount of Fe Oxalate - metallic species and inhomogeneities

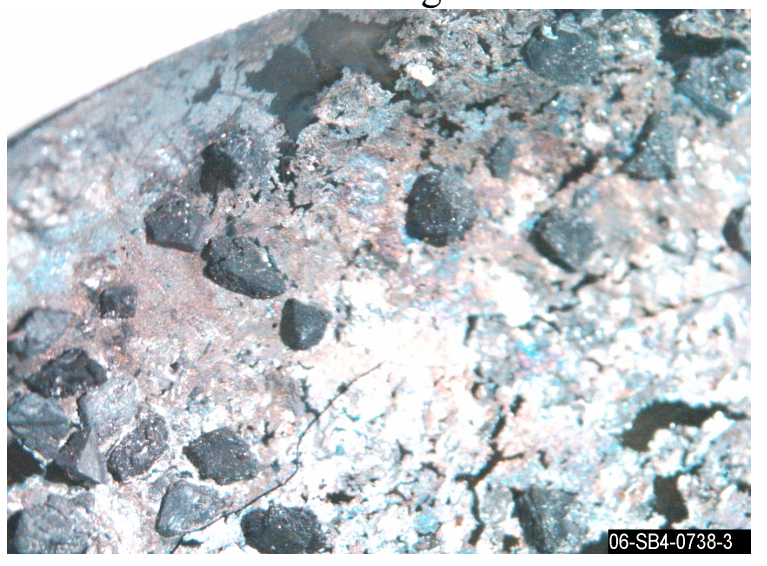

Full coal - coal persisted on glass surface after 1 and 4 hours at $1150^{\circ} \mathrm{C}$.

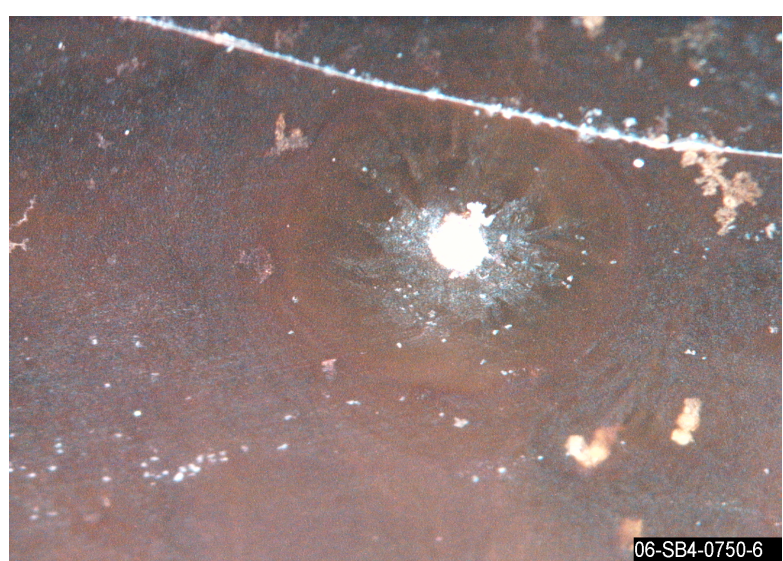

Full amount of $\mathrm{Ca}$ Oxalate - metallic species and inhomogeneities

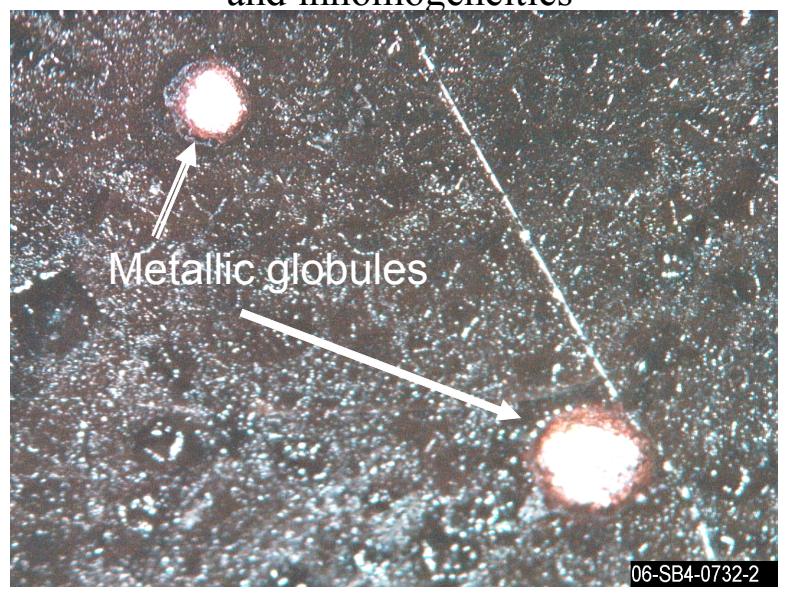

Full coal - formed metallic globules in localized areas near coal particles.

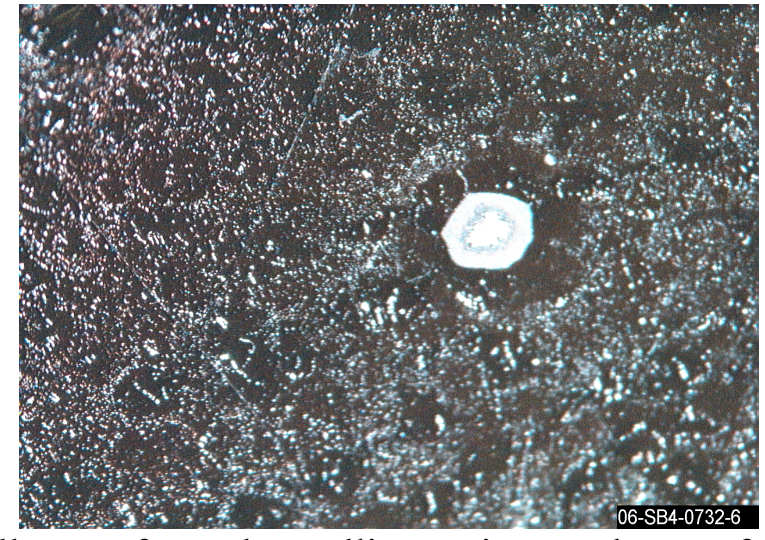

Full sugar formed metallic species on glass surfaces.

Figure 18. SB4 inhomogeneities and metallic species caused by excess alternate reductant. 
Table 5. REDOX Model Data (Historic, SB3 and SB4).

\begin{tabular}{|c|c|c|c|c|c|c|c|c|c|c|c|c|c|c|c|c|c|}
\hline 光 & 吾 & $\sum_{\substack{|c| \\
\sum}}^{E}$ & 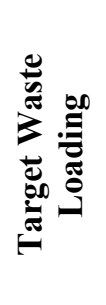 & $\begin{array}{l}\frac{\pi}{2} \\
\frac{\pi}{\sigma} \\
\frac{\pi}{a}\end{array}$ & 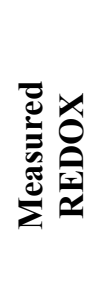 & $\mathbb{F}_{0}$ & \# & 莍 & $\sum_{0}$ & 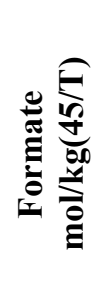 & 疍 & 产 & 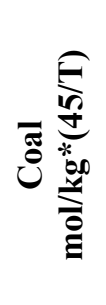 & 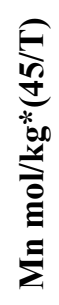 & 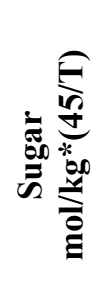 & 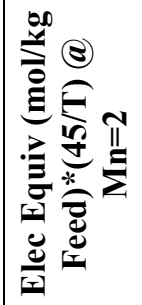 & 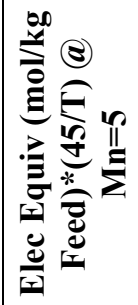 \\
\hline
\end{tabular}

HISTORIC REDOX MODEL DATA (FROM TABLE I IN REFERENCE 12)

\begin{tabular}{|c|c|c|c|c|c|c|c|c|c|c|c|c|c|}
\hline S9-L-F300 & 200 & SME & 0.566 & 1 & 45 & 1.559 & 0.239 & 0.000 & 0.000 & 0.091 & 0.000 & 1.743 & 1.47 \\
\hline S9-L-F800 & 200 & SME & 0.587 & 1 & 45 & 1.587 & 0.229 & 0.000 & 0.000 & 0.091 & 0.000 & 1.846 & 1.573 \\
\hline S9-L-F800 & 200 & SME & 0.514 & 1 & 45 & 1.630 & 0.233 & 0.000 & 0.000 & 0.091 & 0.000 & 1.913 & 1.64 \\
\hline S9-L-N1000 & 200 & SME & 0.157 & 1 & 45 & 1.468 & 0.512 & 0.000 & 0.000 & 0.091 & 0.000 & 0.194 & -0.08 \\
\hline S9-L-N1000 & 200 & SME & 0.204 & 1 & 45 & 1.381 & 0.469 & 0.000 & 0.000 & 0.091 & 0.000 & 0.234 & -0.039 \\
\hline S9-L-N50 & 200 & SME & 0.511 & 1 & 45 & 1.394 & 0.236 & 0.000 & 0.000 & 0.091 & 0.000 & 1.424 & 1.151 \\
\hline S9-L-N50 & 200 & SME & 0.536 & 1 & 45 & 1.222 & 0.215 & 0.000 & 0.000 & 0.091 & 0.000 & 1.187 & 0.914 \\
\hline S9-L-N500 & 200 & SME & 0.361 & 1 & 45 & 1.522 & 0.373 & 0.000 & 0.000 & 0.091 & 0.000 & 0.996 & 0.723 \\
\hline S9-L-N500 & 200 & SME & 0.393 & 1 & 45 & 1.387 & 0.328 & 0.000 & 0.000 & 0.091 & 0.000 & 0.954 & 0.681 \\
\hline S9-L-P1500 & 200 & SME & 0.479 & 1 & 45 & 1.562 & 0.253 & 0.000 & 0.000 & 0.091 & 0.000 & 1.678 & 1.405 \\
\hline S9-L-P1500 & 200 & SME & 0.511 & 1 & 45 & 1.428 & 0.232 & 0.000 & 0.000 & 0.091 & 0.000 & 1.517 & 1.243 \\
\hline S9-L-P3000 & 200 & SME & 0.522 & 1 & 45 & 0.913 & 0.167 & 0.000 & 0.000 & 0.091 & 0.000 & 0.806 & 0.533 \\
\hline S9-L-P3000 & 200 & SME & 0.482 & 1 & 45 & 1.139 & 0.203 & 0.000 & 0.000 & 0.091 & 0.000 & 1.08 & 0.807 \\
\hline S9-L-P200 & 200 & SME & 0.519 & 1 & 45 & 1.279 & 0.226 & 0.000 & 0.000 & 0.091 & 0.000 & 1.248 & 0.975 \\
\hline S9-L-P200 & 200 & SME & 0.538 & 1 & 45 & 1.307 & 0.242 & 0.000 & 0.000 & 0.091 & 0.000 & 1.221 & 0.948 \\
\hline S10-L-F1500 & 168 & SME & 0.563 & 1 & 45 & 1.397 & 0.096 & 0.000 & 0.000 & 0.109 & 0.000 & 2.096 & 1.768 \\
\hline S10-L-F1500 & 168 & SME & 0.707 & 1 & 45 & 1.307 & 0.094 & 0.000 & 0.000 & 0.109 & 0.000 & 1.924 & 1.597 \\
\hline S10-L-F300 & 168 & SME & 0.516 & 1 & 45 & 1.108 & 0.105 & 0.000 & 0.000 & 0.109 & 0.000 & 1.471 & 1.143 \\
\hline S10-L-F300 & 168 & SME & 0.471 & 1 & 45 & 1.070 & 0.103 & 0.000 & 0.000 & 0.109 & 0.000 & 1.409 & 1.081 \\
\hline S10-L-F800 & 168 & SME & 0.509 & 1 & 45 & 1.131 & 0.094 & 0.000 & 0.000 & 0.109 & 0.000 & 1.57 & 1.243 \\
\hline S10-L-F800 & 168 & SME & 0.63 & 1 & 45 & 1.139 & 0.094 & 0.000 & 0.000 & 0.109 & 0.000 & 1.588 & 1.26 \\
\hline S10-L-N100 & 168 & SME & 0.442 & 1 & 45 & 0.990 & 0.128 & 0.000 & 0.000 & 0.109 & 0.000 & 1.12 & 0.792 \\
\hline S10-L-N100 & 168 & SME & 0.364 & 1 & 45 & 1.006 & 0.133 & 0.000 & 0.000 & 0.109 & 0.000 & 1.129 & 0.801 \\
\hline S10-L-N1000 & 168 & SME & 0.129 & 1 & 45 & 1.052 & 0.339 & 0.000 & 0.000 & 0.109 & 0.000 & 0.193 & -0.135 \\
\hline S10-L-N1000 & 168 & SME & 0.152 & 1 & 45 & 0.954 & 0.328 & 0.000 & 0.000 & 0.109 & 0.000 & 0.05 & -0.277 \\
\hline S10-L-N500 & 168 & SME & 0.237 & 1 & 45 & 1.003 & 0.241 & 0.000 & 0.000 & 0.109 & 0.000 & 0.582 & 0.254 \\
\hline
\end{tabular}


WSRC-STI-2006-00066

Revision 0

\begin{tabular}{|c|c|c|c|c|c|c|c|c|c|c|c|c|c|c|c|c|c|}
\hline 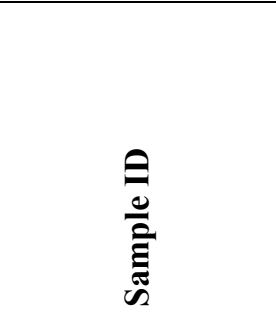 & 莣 & 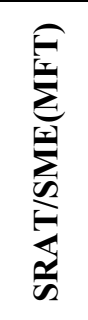 & 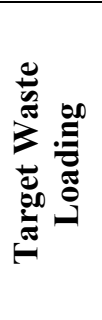 & $\begin{array}{l}\frac{\pi}{2} \\
\frac{2}{a} \\
\frac{\pi}{a}\end{array}$ & 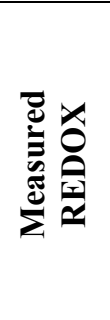 & $\begin{array}{l}\text { Fo }_{0} \\
\text { s. }\end{array}$ & \# & : & $\sum_{i=5}^{+5}$ & 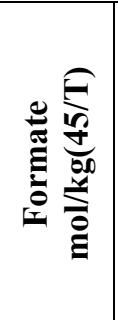 & 疍 & 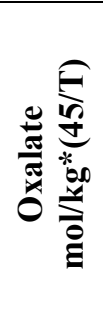 & 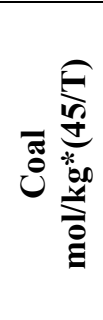 & 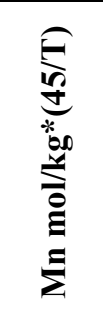 & 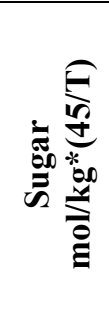 & 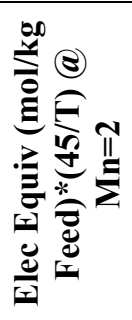 & 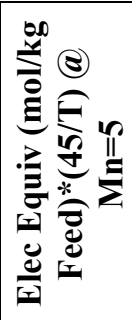 \\
\hline S10-L-N500 & 168 & SME & & & 0.249 & & 1 & & 45 & 0.998 & 0.242 & 0.000 & 0.000 & 0.109 & 0.000 & 0.566 & 0.238 \\
\hline S10-L-P200 & 168 & SME & & & 0.393 & & 1 & & 45 & \begin{tabular}{|l|}
1.013 \\
\end{tabular} & 0.106 & 0.000 & 0.000 & 0.109 & 0.000 & 1.275 & 0.947 \\
\hline S10-L-P200 & 168 & SME & & & 0.384 & & 1 & & 45 & 1.059 & 0.107 & 0.000 & 0.000 & 0.109 & 0.000 & 1.366 & 1.038 \\
\hline S10-L-N50 & 168 & SME & & & 0.434 & & 1 & & 45 & 0.856 & 0.095 & 0.000 & 0.000 & 0.109 & 0.000 & 1.02 & 0.692 \\
\hline S10-L-P1500 & 168 & SME & & & 0.441 & & 1 & & 45 & 1.023 & 0.097 & 0.000 & 0.000 & 0.109 & 0.000 & 1.343 & 1.015 \\
\hline S10-L-P1500 & 168 & SME & & & 0.365 & & 1 & & 45 & 1.039 & 0.100 & 0.000 & 0.000 & 0.109 & 0.000 & 1.36 & 1.032 \\
\hline S10-L-P3000 & 168 & SME & & & 0.445 & & 1 & & 45 & 1.135 & 0.101 & 0.000 & 0.000 & 0.109 & 0.000 & 1.545 & 1.218 \\
\hline S10-L-P3000 & 168 & SME & & & 0.468 & & 1 & & 45 & 0.967 & 0.098 & 0.000 & 0.000 & 0.109 & 0.000 & 1.227 & 0.899 \\
\hline S10-L-P500 & 168 & SME & & & 0.391 & & 1 & & 45 & 0.983 & 0.105 & 0.000 & 0.000 & 0.109 & 0.000 & 1.224 & 0.897 \\
\hline S10-L-P500 & 168 & SME & & & 0.429 & & 1 & & 45 & 1.019 & 0.103 & 0.000 & 0.000 & 0.109 & 0.000 & 1.308 & 0.98 \\
\hline I-L-P1500 & 202 & SME & & & 0.033 & & 1 & & 45 & \begin{tabular}{|l|}
1.011 \\
\end{tabular} & 0.549 & 0.000 & 0.000 & 0.084 & 0.000 & -0.889 & -1.14 \\
\hline I-L-P200 & 202 & SME & & & 0.035 & & 1 & & 45 & 0.975 & 0.517 & 0.000 & 0.000 & 0.084 & 0.000 & -0.801 & -1.052 \\
\hline I-L-P3000 & 202 & SME & & & 0.063 & & 1 & & 45 & 0.911 & 0.482 & 0.000 & 0.000 & 0.084 & 0.000 & -0.756 & -1.007 \\
\hline I-L-PF1500 & 202 & SME & & & 0.077 & & 1 & & 45 & 1.289 & 0.499 & 0.000 & 0.000 & 0.084 & 0.000 & -0.083 & -0.334 \\
\hline I-L-PF1500 & 202 & SME & & & 0.131 & & 1 & & 45 & 1.342 & 0.537 & 0.000 & 0.000 & 0.084 & 0.000 & -0.169 & -0.42 \\
\hline I-L-PF5/8 & 202 & SME & & & 0.063 & & 1 & & 45 & 1.291 & 0.555 & 0.000 & 0.000 & 0.084 & 0.000 & -0.359 & -0.61 \\
\hline I-L-PF5/8 & 202 & SME & & & 0.126 & & 1 & & 45 & 1.227 & 0.527 & 0.000 & 0.000 & 0.084 & 0.000 & -0.35 & -0.601 \\
\hline $26-1000$ & 202 & SME & & & 0.071 & & 1 & & 45 & 0.833 & 0.292 & 0.000 & 0.000 & 0.091 & 0.000 & 0.022 & -0.251 \\
\hline $27-250$ & 202 & SME & & & 0.07 & & 1 & & 45 & 0.406 & 0.260 & 0.000 & 0.000 & 0.091 & 0.000 & -0.67 & -0.943 \\
\hline $27-750$ & 202 & SME & & & 0.068 & & 1 & & 45 & 0.571 & 0.219 & 0.000 & 0.000 & 0.091 & 0.000 & -0.134 & -0.407 \\
\hline $27-750$ & 202 & SME & & & 0.077 & & 1 & & 45 & 0.502 & 0.191 & 0.000 & 0.000 & 0.091 & 0.000 & -0.135 & -0.408 \\
\hline DWPF-Batch1-9 & 202 & SME & & & 0.25 & & 1 & & 45 & 1.016 & 0.302 & 0.000 & 0.000 & 0.089 & 0.000 & 0.344 & 0.077 \\
\hline DWPF-Batch1-9 & 202 & SME & & & 0.08 & & 1 & & 45 & 0.935 & 0.302 & 0.000 & 0.000 & 0.089 & 0.000 & 0.182 & -0.085 \\
\hline DWPF-Batch1-10 & 202 & SME & & & 0.23 & & 1 & & 45 & 0.935 & 0.272 & 0.000 & 0.000 & 0.089 & 0.000 & 0.33 & 0.062 \\
\hline DWPF-Batch1-10 & 202 & SME & & & 0.17 & & 1 & & 45 & 0.913 & 0.317 & 0.000 & 0.000 & 0.089 & 0.000 & 0.065 & -0.203 \\
\hline DWPF-Batch1-11 & 202 & SME & & & 0.23 & & 1 & & 45 & 0.545 & 0.295 & 0.000 & 0.000 & 0.089 & 0.000 & -0.561 & -0.829 \\
\hline DWPF-Batch1-11 & 202 & SME & & & 0.16 & & 1 & & 45 & 0.501 & 0.317 & 0.000 & 0.000 & 0.089 & 0.000 & -0.76 & -1.028 \\
\hline DWPF-Batch1-12 & 202 & SME & & & 0.17 & & 1 & & 45 & 0.530 & 0.302 & 0.000 & 0.000 & 0.089 & 0.000 & -0.628 & -0.895 \\
\hline DWPF-Batch1-12 & 202 & SME & & & 0.15 & & 1 & & 45 & 0.523 & 0.317 & 0.000 & 0.000 & 0.089 & 0.000 & -0.716 & -0.984 \\
\hline
\end{tabular}




\begin{tabular}{|c|c|c|c|c|c|c|c|c|c|c|c|c|c|c|c|c|c|}
\hline 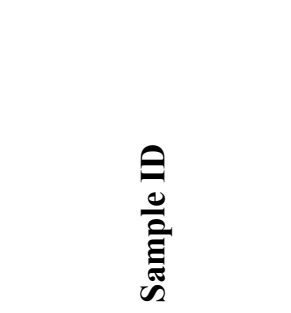 & $\stackrel{\vec{E}}{\vec{E}}$ & 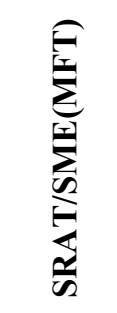 & 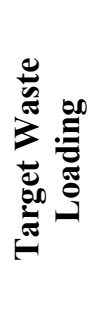 & $\begin{array}{l}\frac{\pi}{2} \\
\frac{\pi}{2} \\
\frac{\pi}{n}\end{array}$ & 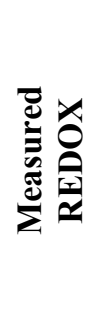 & $\begin{array}{l}F_{0} \\
\text { to }\end{array}$ & 总 & & $\sum_{\infty}^{\infty}$ & 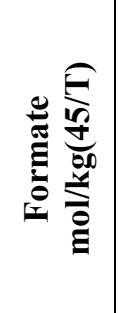 & 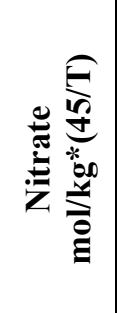 & 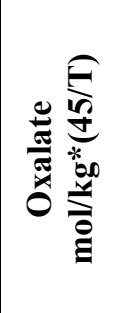 & 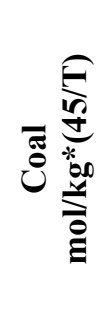 & 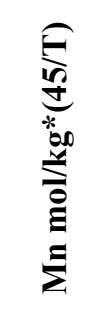 & 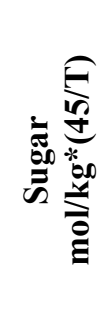 & 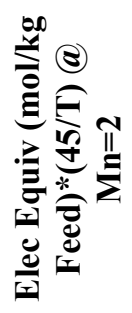 & 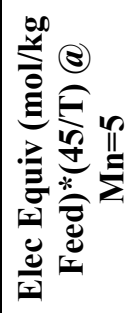 \\
\hline DWPF-Batch1-13 & 202 & SME & & & 0.21 & & 1 & & 45 & 0.663 & 0.295 & 0.000 & 0.000 & 0.089 & 0.000 & -0.326 & -0.593 \\
\hline DWPF-Batch1-13 & 202 & SME & & & 0.09 & & 1 & & 45 & 0.685 & 0.324 & 0.000 & 0.000 & 0.089 & 0.000 & -0.429 & -0.696 \\
\hline DWPF-Batch1-14 & 202 & SME & & & 0.25 & & 1 & & 45 & 0.648 & 0.287 & 0.000 & 0.000 & 0.089 & 0.000 & -0.318 & -0.586 \\
\hline DWPF-Batch1-14 & 202 & SME & & & 0.17 & & 1 & & 45 & 0.611 & 0.295 & 0.000 & 0.000 & 0.089 & 0.000 & -0.429 & -0.696 \\
\hline DWPF-Batch1-15 & 202 & SME & & & 0.11 & & 1 & & 45 & 0.641 & 0.287 & \begin{tabular}{|l|}
0.000 \\
\end{tabular} & 0.000 & 0.089 & 0.000 & -0.333 & -0.601 \\
\hline DWPF-Batch1-15 & 202 & SME & & & 0.19 & & 1 & & 45 & 0.633 & 0.317 & \begin{tabular}{|l|}
0.000 \\
\end{tabular} & 0.000 & 0.089 & 0.000 & -0.495 & -0.763 \\
\hline DWPF-Batch1-22 & 202 & SME & & & 0.07 & & 1 & & 45 & 0.560 & 0.317 & 0.000 & 0.000 & 0.089 & 0.000 & -0.642 & -0.91 \\
\hline DWPF-Batch1-16 & 202 & SME & & & 0.27 & & 1 & & 45 & 0.515 & 0.221 & 0.000 & 0.000 & 0.089 & 0.000 & -0.252 & -0.52 \\
\hline DWPF-Batch1-16 & 202 & SME & & & 0.12 & & 1 & & 45 & 0.457 & 0.243 & 0.000 & 0.000 & 0.089 & 0.000 & -0.48 & -0.748 \\
\hline DWPF-Batch1-21 & 202 & SME & & & 0.16 & & 1 & & 45 & 0.530 & 0.272 & 0.000 & 0.000 & 0.089 & 0.000 & -0.48 & \begin{tabular}{|l|}
-0.748 \\
\end{tabular} \\
\hline DWPF-Batch1-21 & 202 & SME & & & 0.11 & & 1 & & 45 & 0.604 & 0.331 & 0.000 & 0.000 & 0.089 & 0.000 & -0.628 & -0.895 \\
\hline DWPF-Batch1-22 & 202 & SME & & & 0.17 & & 1 & & 45 & 0.508 & 0.265 & \begin{tabular}{|l|}
0.000 \\
\end{tabular} & 0.000 & 0.089 & 0.000 & -0.488 & -0.755 \\
\hline \multicolumn{18}{|c|}{ SB3 REDOX MODEL DATA (FROM TABLE V IN REFERENCE 15) } \\
\hline SB3-1-25-320A & 320 & SRAT & 25 & & 0.12 & 0.049 & 4 & 0.407 & 42.8 & 0.338 & 0.162 & 0.000 & 0.000 & 0.069 & 0.000 & -0.271 & -0.477 \\
\hline SB3-1-30-320A & 320 & SRAT & 30 & . & 0.07 & 0.029 & 4 & 0.393 & 38.75 & 0.399 & 0.191 & 0.000 & 0.000 & 0.081 & 0.000 & -0.321 & \begin{tabular}{|l|}
-0.564 \\
\end{tabular} \\
\hline SB3-5-30-320A & 320 & SRAT & 30 & 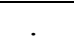 & 0.41 & 0.176 & 4 & 0.433 & 45.09 & 0.387 & 0.188 & 0.264 & 0.000 & 0.061 & 0.000 & 0.766 & 0.584 \\
\hline SB3-5-35-320A & 320 & SRAT & 35 & - & 0.45 & 0.223 & 4 & 0.494 & 41.78 & 0.443 & 0.216 & 0.302 & 0.000 & 0.069 & 0.000 & 0.877 & 0.668 \\
\hline SB3-6-25-320A & 320 & SRAT & 25 & . & 0.37 & 0.131 & 4 & 0.353 & 46.66 & 0.347 & 0.134 & \begin{tabular}{|l|}
0.124 \\
\end{tabular} & 0.000 & 0.058 & 0.000 & 0.400 & 0.225 \\
\hline SB3-6-30-320A & 320 & SRAT & 30 & . & 0.27 & 0.104 & 4 & 0.390 & 42.58 & 0.409 & 0.158 & \begin{tabular}{|l|}
0.146 \\
\end{tabular} & 0.000 & 0.069 & 0.000 & 0.472 & 0.265 \\
\hline SB3-7-25-320A & 320 & SRAT & 25 & & 0.12 & 0.042 & 4 & 0.337 & 42.01 & 0.325 & 0.284 & \begin{tabular}{|l|}
0.254 \\
\end{tabular} & 0.000 & 0.053 & 0.000 & 0.141 & -0.016 \\
\hline SB3-7-30-320A & 320 & SRAT & 30 & & 0.19 & 0.075 & 4 & 0.387 & 38.15 & 0.382 & 0.334 & \begin{tabular}{|l|}
0.298 \\
\end{tabular} & 0.000 & 0.062 & 0.000 & 0.166 & \begin{tabular}{|l|}
-0.019 \\
\end{tabular} \\
\hline SB3-7-35-320A & 320 & SRAT & 35 & $\cdot$ & 0.14 & 0.061 & 4 & 0.427 & 35.07 & 0.436 & 0.381 & \begin{tabular}{|l|}
0.341 \\
\end{tabular} & 0.000 & 0.070 & 0.000 & 0.190 & -0.022 \\
\hline SB3-15-30-320A & 320 & SRAT & 30 & 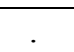 & 0.33 & 0.129 & 4 & 0.390 & 39.04 & 0.660 & 0.285 & 0.228 & 0.007 & 0.065 & 0.000 & 0.702 & 0.507 \\
\hline SB3-1-25-202A & 202 & SRAT & 25 & & 0.10 & 0.028 & 4 & 0.263 & 42.84 & 0.337 & 0.162 & 0.000 & 0.000 & 0.069 & 0.000 & -0.271 & -0.476 \\
\hline SB3-1-35-202A & 202 & SRAT & 35 & . & 0.12 & 0.032 & 4 & 0.267 & 35.5 & 0.459 & 0.220 & 0.000 & 0.000 & 0.093 & 0.000 & -0.369 & -0.649 \\
\hline SB3-2-25-200A & 200 & SRAT & 25 & . & 0.24 & 0.101 & 4 & 0.415 & 42.99 & 0.321 & 0.167 & 0.000 & 0.082 & 0.064 & 0.000 & 0.006 & -0.185 \\
\hline SB3-2-30-200A & 200 & SRAT & 30 & & 0.21 & 0.083 & 4 & 0.389 & 38.91 & 0.380 & 0.198 & 0.000 & 0.097 & 0.076 & 0.000 & 0.008 & -0.219 \\
\hline SB3-2-35-200A & 200 & SRAT & 35 & & 0.14 & 0.053 & 4 & 0.391 & 35.65 & 0.437 & 0.227 & 0.000 & 0.111 & 0.087 & 0.000 & 0.009 & -0.252 \\
\hline
\end{tabular}


WSRC-STI-2006-00066

Revision 0

\begin{tabular}{|c|c|c|c|c|c|c|c|c|c|c|c|c|c|c|c|c|c|}
\hline 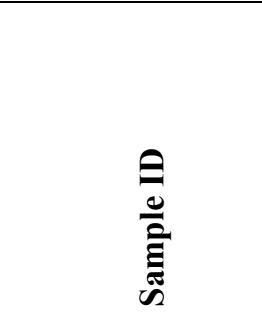 & $\underset{E}{E}$ & 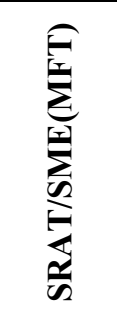 & 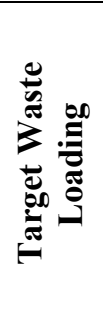 & $\begin{array}{l}\frac{\pi}{2} \\
\frac{5}{\sqrt[a]{2}} \\
\frac{\sqrt{2}}{\infty}\end{array}$ & 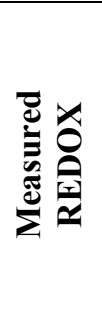 & $\begin{array}{l}\text { fo } \\
\text { fo }\end{array}$ & \# & & $\sum_{\infty}^{b}$ & 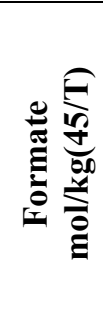 & & 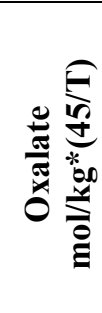 & 点 & 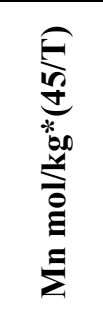 & 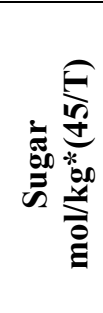 & 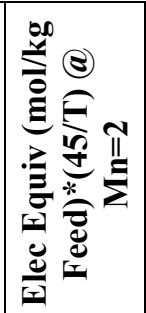 & 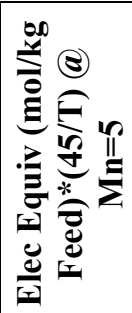 \\
\hline SB3-3-25-200A & 200 & SRAT & 25 & . & 0.28 & 0.128 & 4 & 0.463 & 43.85 & 0.409 & 0.166 & 0.000 & 0.080 & 0.060 & 0.000 & 0.189 & 0.009 \\
\hline SB3-4-25-202A & 202 & SRAT & 25 & . & 0.14 & 0.048 & 4 & 0.349 & 43.24 & 0.314 & 0.170 & 0.000 & 0.082 & 0.066 & 0.000 & -0.027 & -0.225 \\
\hline SB3-6-25-202A & 202 & SRAT & 25 & . & 0.34 & 0.102 & 4 & 0.304 & 46.67 & 0.347 & 0.134 & 0.124 & 0.000 & 0.058 & 0.000 & 0.400 & 0.225 \\
\hline SB3-6-30-202A & 202 & SRAT & 30 & . & 0.29 & 0.112 & 4 & 0.388 & 42.58 & 0.409 & 0.158 & 0.146 & 0.000 & 0.069 & 0.000 & 0.472 & 0.265 \\
\hline SB3-7-25-202A & 202 & SRAT & 25 & . & 0.19 & 0.093 & 4 & 0.483 & 42.01 & 0.325 & 0.284 & 0.254 & 0.000 & 0.053 & 0.000 & 0.141 & \begin{tabular}{|l|}
-0.016 \\
\end{tabular} \\
\hline SB3-7-30-202A & 202 & SRAT & 30 & . & 0.14 & 0.062 & 4 & 0.439 & 38.15 & 0.382 & 0.334 & 0.298 & 0.000 & 0.062 & 0.000 & 0.166 & \begin{tabular}{|l|}
-0.019 \\
\end{tabular} \\
\hline SB3-7-35-202A & 202 & SRAT & 35 & . & 0.16 & 0.058 & 4 & 0.370 & 35.07 & 0.436 & 0.381 & 0.341 & 0.000 & 0.070 & 0.000 & 0.190 & \begin{tabular}{|l|}
-0.022 \\
\end{tabular} \\
\hline SB3-8-25-202A & 202 & SRAT & 25 & . & 0.27 & 0.097 & 4 & 0.357 & 41.79 & 0.322 & 0.286 & 0.252 & 0.064 & 0.051 & 0.000 & 0.373 & 0.220 \\
\hline SB3-8-35-202A & 202 & SRAT & 35 & . & 0.18 & 0.087 & 4 & 0.493 & 34.91 & 0.430 & 0.383 & 0.337 & 0.085 & 0.069 & 0.000 & 0.500 & 0.294 \\
\hline SB3-9-25-202A & 202 & SRAT & 25 & . & 0.24 & 0.096 & 4 & 0.395 & 42.89 & 0.343 & 0.230 & 0.239 & 0.062 & 0.054 & 0.000 & 0.631 & 0.469 \\
\hline SB3-9-30-202A & 202 & SRAT & 30 & . & 0.22 & 0.089 & 4 & 0.396 & 39.02 & 0.403 & 0.270 & 0.280 & 0.072 & 0.063 & 0.000 & 0.740 & 0.550 \\
\hline SB3-10-35-202A & 202 & SRAT & 35 & . & 0.34 & 0.139 & 4 & 0.407 & 35.71 & 0.519 & 0.286 & 0.262 & 0.008 & 0.070 & 0.000 & 0.549 & 0.338 \\
\hline SB3-11-25-202A & 202 & SRAT & 25 & . & 0.39 & 0.122 & 4 & 0.315 & 42.79 & 0.430 & 0.199 & 0.189 & 0.006 & 0.054 & 0.000 & 0.539 & 0.376 \\
\hline SB3-12-25-202A & 202 & SRAT & 25 & . & 0.33 & 0.116 & 4 & 0.346 & 43.03 & 0.443 & 0.248 & 0.194 & 0.062 & 0.053 & 0.000 & 0.562 & 0.401 \\
\hline SB3-12-30-202A & 202 & SRAT & 30 & . & 0.35 & 0.144 & 4 & 0.415 & 39.21 & 0.519 & 0.290 & 0.227 & 0.072 & 0.063 & 0.000 & 0.658 & 0.470 \\
\hline SB3-13-25-202A & 202 & SRAT & 25 & . & 0.34 & 0.108 & 4 & 0.316 & 43.15 & 0.507 & 0.264 & 0.210 & 0.062 & 0.055 & 0.000 & 0.670 & 0.504 \\
\hline SB3-13-30-202A & 202 & SRAT & 30 & . & 0.35 & 0.129 & 4 & 0.366 & 39.31 & 0.594 & 0.310 & 0.247 & 0.073 & 0.065 & 0.000 & 0.785 & 0.590 \\
\hline SB3-14-30-202A & 202 & SRAT & 30 & . & 0.37 & 0.142 & 4 & 0.383 & 39.01 & 0.508 & 0.272 & 0.253 & 0.008 & 0.064 & 0.000 & 0.568 & 0.376 \\
\hline SB3-15-25-202A & 202 & SRAT & 25 & . & 0.38 & 0.125 & 4 & 0.326 & 42.87 & 0.564 & 0.244 & 0.194 & 0.006 & 0.056 & 0.000 & 0.600 & 0.433 \\
\hline SB3-15-30-202A & 202 & SRAT & 30 & . & 0.36 & 0.169 & 4 & 0.469 & 39.04 & 0.661 & 0.285 & 0.228 & 0.007 & 0.065 & 0.000 & 0.703 & 0.507 \\
\hline SB3-16-25-202A & 202 & SRAT & 25 & . & 0.32 & 0.119 & 4 & 0.371 & 42.52 & 0.436 & 0.264 & 0.225 & 0.062 & 0.056 & 0.000 & 0.588 & 0.421 \\
\hline SB3-18-25-202A & 202 & SRAT & 25 & . & 0.04 & 0.017 & 4 & 0.384 & 43.32 & 0.430 & 0.230 & 0.000 & 0.081 & 0.068 & 0.000 & -0.104 & \begin{tabular}{|l|}
-0.309 \\
\end{tabular} \\
\hline SB3-22-30-320 & 320 & SME & 30 & . & 0.41 & 0.176 & 4 & 0.430 & 49 & 1.077 & 0.594 & 0.282 & 0.077 & 0.000 & 0.000 & 0.621 & 0.621 \\
\hline SB3-23-30-320 & 320 & SME & 30 & . & 0.22 & 0.110 & 4 & 0.502 & 47.4 & 0.730 & 0.446 & 0.187 & 0.087 & 0.000 & 0.000 & 0.326 & 0.326 \\
\hline SB3-24-25-202 & 202 & SRAT & 25 & . & 0.41 & 0.113 & 4 & 0.275 & 42.32 & 0.263 & 0.326 & 0.533 & 0.066 & 0.035 & 0.000 & 1.221 & 1.116 \\
\hline SB3-24-30-202 & 202 & SRAT & 30 & . & 0.45 & 0.127 & 4 & 0.281 & 38.54 & 0.308 & 0.382 & 0.623 & 0.078 & 0.041 & 0.000 & 1.428 & 1.306 \\
\hline SB3-A1-25-202 & 202 & SRAT & 25 & . & 0.37 & 0.126 & 4 & 0.339 & 41.19 & 0.540 & 0.346 & 0.402 & 0.063 & 0.072 & 0.000 & 1.068 & 0.851 \\
\hline SB3-A1-30-202 & 202 & SRAT & 30 & . & 0.34 & 0.110 & 4 & 0.327 & 37.53 & 0.630 & 0.403 & 0.468 & 0.074 & 0.084 & 0.000 & 1.245 & 0.992 \\
\hline SB3-A1-35-202 & 202 & SRAT & 35 & 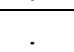 & 0.37 & 0.177 & 4 & 0.477 & 34.63 & 0.714 & 0.457 & 0.531 & 0.084 & 0.095 & 0.000 & 1.412 & 1.125 \\
\hline
\end{tabular}




\begin{tabular}{|c|c|c|c|c|c|c|c|c|c|c|c|c|c|c|c|c|c|}
\hline 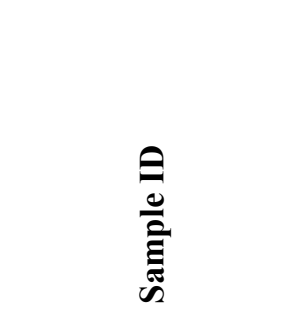 & 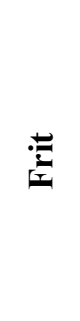 & $\sum_{\substack{|c| \\
\sum_{\infty}^{|c|}}}$ & 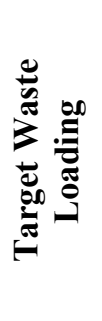 & $\begin{array}{l}\frac{\pi}{2} \\
\bar{n} \\
\frac{\pi}{\infty}\end{array}$ & 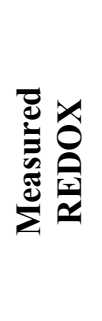 & $\begin{array}{l}F_{0} \\
F_{0}\end{array}$ & \# & & $\sum_{i=1}^{n}$ & 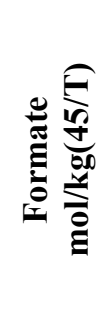 & 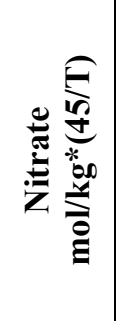 & 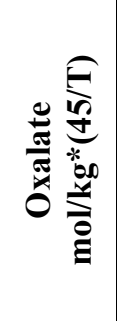 & 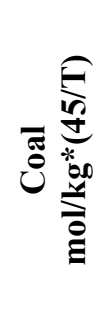 & 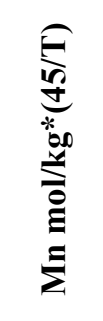 & 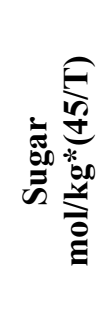 & 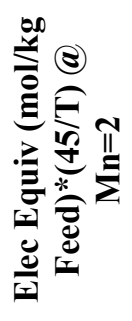 & 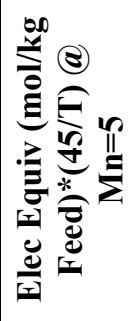 \\
\hline SB3-A2-25-202 & 202 & SRAT & 25 & . & 0.38 & 0.132 & 4 & 0.346 & 46.69 & 0.399 & 0.232 & 0.193 & 0.069 & 0.087 & 0.000 & 0.512 & 0.252 \\
\hline SB3-A2-30-202 & 202 & SRAT & 30 & . & 0.21 & 0.083 & 4 & 0.399 & 39.79 & 0.528 & 0.307 & 0.256 & 0.091 & 0.115 & 0.000 & 0.678 & 0.334 \\
\hline SB3-A2-35-202 & 202 & SRAT & 35 & . & 0.31 & 0.125 & 4 & 0.404 & 36.73 & 0.602 & 0.350 & 0.291 & 0.104 & 0.131 & 0.000 & 0.772 & 0.380 \\
\hline SB3-A3-25-202 & 202 & SRAT & 25 & . & 0.29 & 0.056 & 4 & 0.192 & 42.24 & 0.539 & 0.280 & 0.254 & 0.075 & 0.083 & 0.000 & 0.827 & 0.577 \\
\hline SB3-A3-30-202 & 202 & SRAT & 30 & . & 0.37 & 0.124 & 4 & 0.335 & 38.52 & 0.629 & 0.327 & 0.296 & 0.088 & 0.097 & 0.000 & 0.965 & 0.673 \\
\hline SB3-A4-25-202 & 202 & SRAT & 25 & - & 0.20 & 0.102 & 4 & 0.509 & 43.92 & 0.440 & 0.207 & 0.005 & 0.098 & 0.111 & 0.000 & 0.037 & -0.298 \\
\hline SB3-A4-30-202 & 202 & SRAT & 30 & 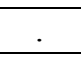 & 0.16 & 0.099 & 4 & 0.608 & 39.94 & 0.518 & 0.243 & 0.006 & 0.116 & 0.131 & 0.000 & 0.043 & -0.350 \\
\hline $\begin{array}{l}\text { MM Feed } 200 \text { SME } \\
\text { (crucible) }\end{array}$ & 200 & SME & 25.5 & . & 0.17 & 0.068 & 4 & 0.394 & 47 & 0.844 & 0.346 & 0.000 & 0.000 & 0.091 & 0.000 & -0.226 & -0.500 \\
\hline $\begin{array}{l}\text { MM Feed } 320 \text { SME } \\
\text { (crucible) }\end{array}$ & 320 & SME & 25.5 & . & 0.18 & 0.064 & 4 & 0.360 & 47 & 0.770 & 0.333 & 0.000 & 0.000 & 0.115 & 0.000 & -0.354 & -0.699 \\
\hline \multicolumn{18}{|c|}{ VALIDATION DATA (FROM TABLE IX IN REFERENCE 15 and SB4 SMRF TESTING) } \\
\hline DWPF SME 224 & 200 & SME & . & $\cdot$ & 0.21 & 0.210 & 6 & 1.000 & 47.7 & 1.291 & 0.506 & 0.000 & 0.000 & 0.052 & 0.000 & -0.052 & -0.207 \\
\hline DWPF SRAT 224 & 200 & SRAT & & . & 0.21 & 0.210 & 6 & 1.000 & 47.7 & 1.329 & 0.583 & 0.000 & 0.000 & 0.000 & 0.000 & -0.259 & -0.259 \\
\hline MMGO25 SRAT & 320 & SRAT & 25.5 & - & 0.12 & 0.120 & 4 & 1.000 & 41.39 & 0.393 & 0.215 & 0.000 & 0.000 & 0.093 & 0.000 & -0.477 & -0.757 \\
\hline MMGO25 SME & 320 & SME & 25.5 & & 0.12 & 0.120 & 4 & 1.000 & 47 & 0.770 & 0.333 & 0.000 & 0.000 & 0.115 & 0.000 & -0.354 & -0.699 \\
\hline SMRF 202 SME & 202 & SME & & & 0.239 & 0.081 & & 0.339 & 47.1 & 0.506 & 0.412 & 0.351 & 0.070 & 0.087 & 0.000 & 0.461 & 0.201 \\
\hline SMRF 202 SRAT & 202 & SRAT & & & 0.239 & 0.081 & & 0.339 & 47.1 & 0.521 & 0.468 & 0.348 & 0.070 & 0.100 & 0.000 & 0.173 & -0.127 \\
\hline SB4-49/50 SMRF & 418 & SRAT & 35 & & 0.064 & & 4 & & 44.15 & 1.734 & 0.633 & 0.000 & 0.000 & 0.131 & 0.000 & 0.039 & -0.354 \\
\hline SB4-51/52A SMRF & 425 & SRAT & 35 & & 0.094 & & 4 & & 44.40 & 1.575 & 0.599 & 0.000 & 0.000 & 0.127 & 0.000 & -0.102 & -0.484 \\
\hline SB4-51/52B SMRF & 425 & SRAT & 35 & & 0.149 & & 4 & & 44.30 & 1.577 & 0.596 & 0.000 & 0.000 & 0.127 & 0.000 & -0.081 & \begin{tabular}{|l|}
-0.463 \\
\end{tabular} \\
\hline SB4-5556 SMRF & 503 & SRAT & 35 & 8.00 & 0.241 & & 4 & & 44.15 & 1.295 & 0.528 & 0.000 & 0.000 & 0.129 & 0.000 & -0.308 & -0.695 \\
\hline \multicolumn{18}{|c|}{ SB4 REDOX MODEL DATA (THIS STUDY) } \\
\hline SB4-32 & & SRAT & & - & 0.01 & & 4 & . & 44.3 & 0.909 & 0.355 & 0.000 & 0.000 & 0.114 & 0.000 & -0.182 & -0.523 \\
\hline SB4 Precursor & & SRAT & & & 0.01 & & 4 & & 44.15 & 0.874 & 0.410 & 0.000 & 0.000 & 0.132 & 0.000 & -0.568 & -0.964 \\
\hline SB4-10-418 & 418 & SRAT & 35 & & 0.00 & 0.012 & 4 & 0.807 & 43.94 & 0.847 & 0.350 & 0.000 & 0.000 & 0.197 & 0.000 & -0.449 & -1.039 \\
\hline SB4-11-418 & 418 & SRAT & 35 & . & 0.00 & 0.000 & 4 & . & 37.43 & 1.067 & 0.413 & 0.000 & 0.000 & 0.231 & 0.000 & -0.392 & -1.084 \\
\hline SB4-19-418 & 418 & SRAT & 35 & 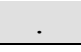 & 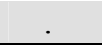 & 0.000 & 4 & 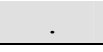 & 36.67 & 1.012 & 0.428 & 0.000 & 0.000 & 0.117 & 0.000 & -0.350 & -0.702 \\
\hline
\end{tabular}


WSRC-STI-2006-00066

Revision 0

\begin{tabular}{|c|c|c|c|c|c|c|c|c|c|c|c|c|c|c|c|c|c|}
\hline$\frac{\varrho}{\frac{0}{E}}$ & 至 & 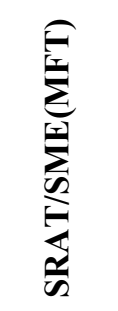 & 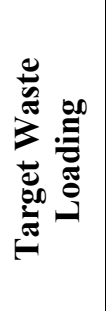 & $\begin{array}{l}\frac{\pi}{2} \\
\frac{5}{\sqrt[n]{2}} \\
\frac{\pi}{2}\end{array}$ & 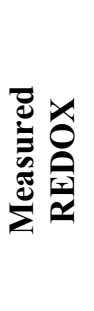 & Fe $_{0}$ & \# & $\frac{0}{\tilde{\sigma}}$ & $\sum_{\infty}^{\infty}$ & 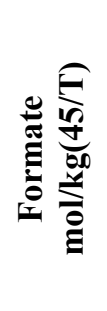 & 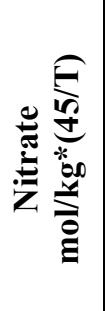 & 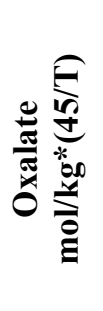 & 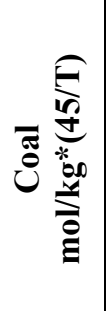 & 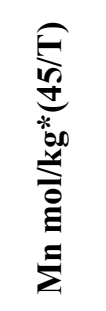 & 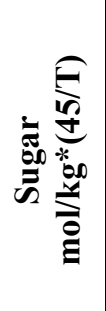 & 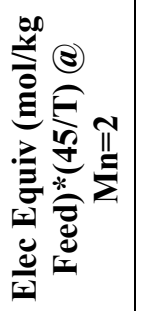 & (o) \\
\hline SB4-20-418 & 418 & SRAT & 35 & . & 0.07 & 0.032 & 4 & 0.468 & 37.78 & 1.193 & 0.541 & 0.000 & 0.000 & 0.123 & 0.000 & -0.565 & -0.935 \\
\hline $\begin{array}{l}\text { SB4-21/22-320- } \\
\text { 43SMRF }\end{array}$ & 320 & SRAT & 43 & . & 0.00 & 0.000 & 4 & 1.500 & 41 & 1.179 & 0.518 & 0.000 & 0.000 & 0.160 & 0.000 & -0.549 & -1.028 \\
\hline $\begin{array}{l}\text { SB4-23/24-418-43 } \\
\text { SMRF }\end{array}$ & 418 & SRAT & 43 & . & 0.00 & 0.000 & 4 & 1.500 & 40.6 & 1.172 & 0.522 & 0.000 & 0.000 & 0.163 & 0.000 & -0.593 & -1.083 \\
\hline $\begin{array}{l}\text { SB4-25/26-320-35- } \\
\text { SMRF }\end{array}$ & 320 & SRAT & 43 & . & 0.00 & 0.000 & 4 & 1.500 & 49.95 & 0.841 & 0.375 & 0.000 & 0.000 & 0.137 & 0.000 & -0.466 & -0.878 \\
\hline $\begin{array}{l}\text { SB4-27/28-418-35- } \\
\text { SMRF }\end{array}$ & 418 & SRAT & 35 & . & 0.00 & 0.000 & 4 & 1.500 & 50.15 & 0.828 & 0.378 & 0.000 & 0.000 & 0.136 & 0.000 & -0.510 & -0.919 \\
\hline SB4RE-32-418-35 & 418 & SRAT & 35 & 9.37 & 0.04 & 0.026 & 4 & 0.622 & 42.39 & 0.832 & 0.324 & 0.000 & 0.000 & 0.134 & 0.000 & -0.223 & -0.625 \\
\hline SB4RE-32-503-35 & 503 & SRAT & 35 & 9.37 & 0.03 & 0.020 & 4 & 0.607 & 42.39 & 0.832 & 0.324 & 0.000 & 0.000 & 0.134 & 0.000 & -0.223 & -0.625 \\
\hline SB4RE-32-P2-2-35 & p2-2 & SRAT & 35 & 9.37 & 0.05 & 0.036 & 4 & 0.783 & 42.39 & 0.832 & 0.324 & 0.000 & 0.000 & 0.134 & 0.000 & -0.223 & -0.625 \\
\hline SB4RE-34-FA only & 418 & SRAT & 35 & . & 0.18 & 0.117 & 4 & 0.657 & 41.79 & 1.176 & 0.291 & 0.000 & 0.000 & 0.122 & 0.000 & 0.654 & 0.288 \\
\hline SB4RE-34-FA only & 503 & SRAT & 35 & . & 0.21 & 0.177 & 4 & 0.850 & 41.79 & 1.176 & 0.291 & 0.000 & 0.000 & 0.122 & 0.000 & 0.654 & 0.288 \\
\hline SB4RE-34-FA only & p2-2 & SRAT & 35 & . & 0.13 & 0.107 & 4 & 0.842 & 41.79 & 1.176 & 0.291 & 0.000 & 0.000 & 0.122 & 0.000 & 0.654 & 0.288 \\
\hline SB4-41-418 & 418 & SRAT & 35 & 7.88 & 0.05 & 0.035 & 4 & 0.760 & 41.66 & 1.053 & 0.437 & 0.000 & 0.000 & 0.119 & 0.000 & -0.314 & -0.671 \\
\hline SB4-41-P2-2 & P2-2 & SRAT & 35 & 7.88 & 0.04 & 0.040 & 4 & 0.930 & 41.66 & 1.053 & 0.437 & 0.000 & 0.000 & 0.119 & 0.000 & -0.314 & -0.671 \\
\hline $\begin{array}{l}\text { SB4-41-418 full } \\
\text { sugar }\end{array}$ & 418 & SRAT & 35 & 7.88 & 0.18 & 0.123 & 4 & 0.700 & 41.66 & 1.053 & 0.437 & 0.000 & 0.000 & 0.119 & 0.700 & 2.486 & 2.129 \\
\hline $\begin{array}{l}\text { SB4-41-418 half } \\
\text { sugar }\end{array}$ & 418 & SRAT & 35 & 7.88 & 0.25 & 0.150 & 4 & 0.610 & 41.66 & 1.053 & 0.437 & 0.000 & 0.000 & 0.119 & 0.350 & 1.086 & 0.729 \\
\hline $\begin{array}{l}\text { SB4-41-418 quarter } \\
\text { sugar }\end{array}$ & 418 & SRAT & 35 & 7.88 & 0.18 & 0.110 & 4 & 0.608 & 41.66 & 1.053 & 0.437 & 0.000 & 0.000 & 0.119 & 0.175 & 0.386 & 0.029 \\
\hline $\begin{array}{l}\text { SB4-41-418 full } \\
\text { coal }\end{array}$ & 418 & SRAT & 35 & 7.88 & 0.32 & 0.170 & 4 & 0.533 & 41.66 & 1.053 & 0.437 & 0.000 & 0.700 & 0.119 & 0.000 & 2.486 & 2.129 \\
\hline $\begin{array}{l}\text { SB4-41-418 half } \\
\text { coal }\end{array}$ & 418 & SRAT & 35 & 7.88 & 0.32 & 0.218 & 4 & 0.688 & 41.66 & 1.053 & 0.437 & 0.000 & 0.350 & 0.119 & 0.000 & 1.086 & 0.729 \\
\hline $\begin{array}{l}\text { SB4-41-418 quarter } \\
\text { coal }\end{array}$ & 418 & SRAT & 35 & 7.88 & 0.40 & 0.263 & 4 & 0.653 & 41.66 & 1.053 & 0.437 & 0.000 & 0.175 & 0.119 & 0.000 & 0.386 & 0.029 \\
\hline
\end{tabular}


WSRC-STI-2006-00066

Revision 0

\begin{tabular}{|c|c|c|c|c|c|c|c|c|c|c|c|c|c|c|c|c|c|}
\hline$\frac{\varrho}{\frac{0}{a}}$ & 吾 & 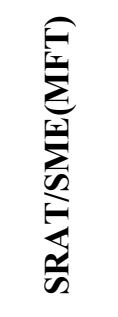 & 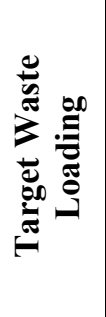 & $\begin{array}{l}\frac{\pi}{2} \\
\frac{2}{\alpha} \\
\frac{1}{n}\end{array}$ & 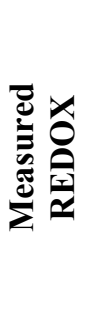 & Fo & \# & $\frac{0}{0}$ & $\sum_{\infty}^{\infty}$ & 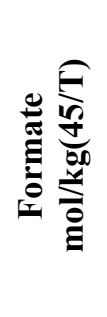 & 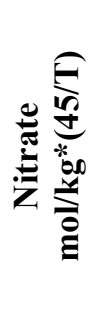 & 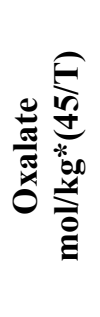 & 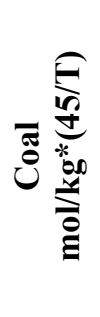 & 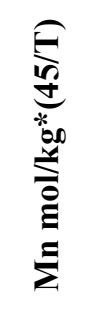 & 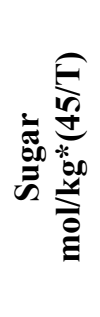 & 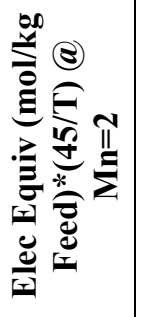 & 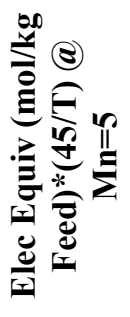 \\
\hline $\begin{array}{l}\text { SB4-41-418 full Fe } \\
\text { Ox }\end{array}$ & 418 & SRAT & 35 & 7.88 & 0.28 & 0.365 & 4 & 1.315 & 41.66 & 1.053 & 0.437 & 0.350 & 0.000 & 0.119 & 0.000 & 1.086 & 0.729 \\
\hline $\begin{array}{l}\text { SB4-41-418 half Fe } \\
\text { Ox }\end{array}$ & 418 & SRAT & 35 & 7.88 & 0.12 & 0.118 & 4 & 0.963 & 41.66 & 1.053 & 0.437 & 0.175 & 0.000 & 0.119 & 0.000 & 0.386 & 0.029 \\
\hline $\begin{array}{l}\text { SB4-41-418 quarter } \\
\text { Fe Ox }\end{array}$ & 418 & SRAT & 35 & 7.88 & 0.11 & 0.070 & 6 & 0.658 & 41.66 & 1.053 & 0.437 & 0.087 & 0.000 & 0.119 & 0.000 & 0.036 & -0.321 \\
\hline $\begin{array}{l}\text { SB4-41-418 full Ca } \\
\text { Ox }\end{array}$ & 418 & SRAT & 35 & 7.88 & 0.33 & 0.185 & 4 & 0.560 & 41.66 & 1.053 & 0.437 & 0.350 & 0.000 & 0.119 & 0.000 & 1.086 & 0.729 \\
\hline $\begin{array}{l}\text { SB4-41-418 half } \mathrm{Ca} \\
\text { Ox }\end{array}$ & 418 & SRAT & 35 & 7.88 & 0.20 & 0.130 & 4 & 0.645 & 41.66 & 1.053 & 0.437 & 0.175 & 0.000 & 0.119 & 0.000 & 0.386 & 0.029 \\
\hline $\begin{array}{l}\text { SB4-41-418 quarter } \\
\text { Ca Ox }\end{array}$ & 418 & SRAT & 35 & 7.88 & 0.09 & 0.060 & 4 & 0.640 & 41.66 & 1.053 & 0.437 & 0.087 & 0.000 & 0.119 & 0.000 & 0.036 & -0.321 \\
\hline $\begin{array}{l}\text { SB4-41-418 full } \\
\text { antifoam } 747(2 \mathrm{~g})\end{array}$ & 418 & SRAT & 35 & 7.88 & 0.57 & 0.353 & 4 & 0.615 & 41.66 & 1.053 & 0.437 & 0.000 & 0.000 & 0.119 & 0.000 & -0.314 & -0.671 \\
\hline $\begin{array}{l}\text { SB4-41-418 1/2 } \\
\text { antifoam } 747(1 \mathrm{~g})\end{array}$ & 418 & SRAT & 35 & 7.88 & 0.53 & 0.299 & 4 & 0.564 & 41.66 & 1.053 & 0.437 & 0.000 & 0.000 & 0.119 & 0.000 & -0.314 & -0.671 \\
\hline $\begin{array}{l}\text { SB4-41-418 full } \\
\text { formic ( } 50 \text { gal) }\end{array}$ & 418 & SRAT & 35 & 7.88 & 0.09 & 0.055 & 4 & 0.603 & 41.66 & 1.053 & 0.437 & 0.000 & 0.000 & 0.119 & 0.000 & -0.314 & -0.671 \\
\hline $\begin{array}{l}\text { SB4-41-418 half } \\
\text { formic }(25 \mathrm{gal})\end{array}$ & 418 & SRAT & 35 & 7.88 & 0.04 & 0.020 & 4 & 0.505 & 41.66 & 1.053 & 0.437 & 0.000 & 0.000 & 0.119 & 0.000 & -0.314 & -0.671 \\
\hline SB4-49 & 418 & SRAT & 35 & . & 0.08 & 0.063 & 8 & 0.801 & 37.38 & 1.293 & 0.491 & 0.000 & 0.000 & 0.154 & 0.000 & -0.178 & -0.639 \\
\hline SB4-51 & 425 & SRAT & 35 & . & 0.07 & 0.067 & 4 & 0.966 & 37.56 & 1.259 & 0.482 & 0.000 & 0.000 & 0.154 & 0.000 & -0.200 & -0.661 \\
\hline SB4-49/50 MIX & 418 & SRAT & 35 & . & 0.08 & 0.063 & 8 & 0.801 & 37.53 & 1.269 & 0.475 & 0.000 & 0.000 & 0.154 & 0.000 & -0.147 & -0.610 \\
\hline SB4-51/52 MIX & 425 & SRAT & 35 & . & 0.07 & 0.067 & 4 & 0.966 & 37.43 & 1.118 & 0.442 & 0.000 & 0.000 & 0.151 & 0.000 & -0.276 & -0.729 \\
\hline SB4-61 & 503 & SRAT & 35 & 8.17 & 0.06 & 0.051 & 4 & 0.913 & 46.65 & 1.303 & 0.370 & 0.000 & 0.000 & 0.140 & 0.000 & 0.478 & 0.058 \\
\hline SB4-62 & 503 & SRAT & 35 & 6.83 & 0.08 & 0.065 & 4 & 0.860 & 47.57 & 1.339 & 0.510 & 0.000 & 0.000 & 0.132 & 0.000 & -0.138 & -0.533 \\
\hline SB4-63 & 503 & SRAT & 35 & 5.27 & 0.08 & 0.075 & 4 & 0.896 & 46.83 & 1.343 & 0.497 & 0.000 & 0.000 & 0.123 & 0.000 & -0.045 & -0.415 \\
\hline SB4-64 & 503 & SRAT & 35 & 4.78 & 0.09 & 0.079 & 2 & 0.894 & 47.13 & 1.422 & 0.476 & 0.000 & 0.000 & 0.123 & 0.000 & 0.220 & -0.148 \\
\hline
\end{tabular}


WSRC-STI-2006-00066

Revision 0

\subsection{REDOX Modeling}

The DWPF EE REDOX model given in Equation 9 (see Section 2.4) is plotted in Figure 19 for the historic and SB3 data points using the electron transfer term of 2 for $\mathrm{Mn}^{+4}$ in the feed going to $\mathrm{Mn}^{+2}$ in the glass. The value of 2 electrons transferred for manganese is the value used in the derivation of the 2003 EE DWPF REDOX model. The SB4 REDOX data is overlain for comparison. In Figure 19 all of the SB4 crucible data shown as the * symbols (crucible data) and solid rectangles are biased to more oxidizing REDOX values than the SB3 and historic REDOX data used to generate the 2003 DWPF EE REDOX model. This bias in the location of the SB4 data in Figure 19 is indicated with an ellipse. Much of the SB4 data fits within the 95\% Lower Confidence (L95) interval of the 2003 EE REDOX model but some of the data is outside the L95.

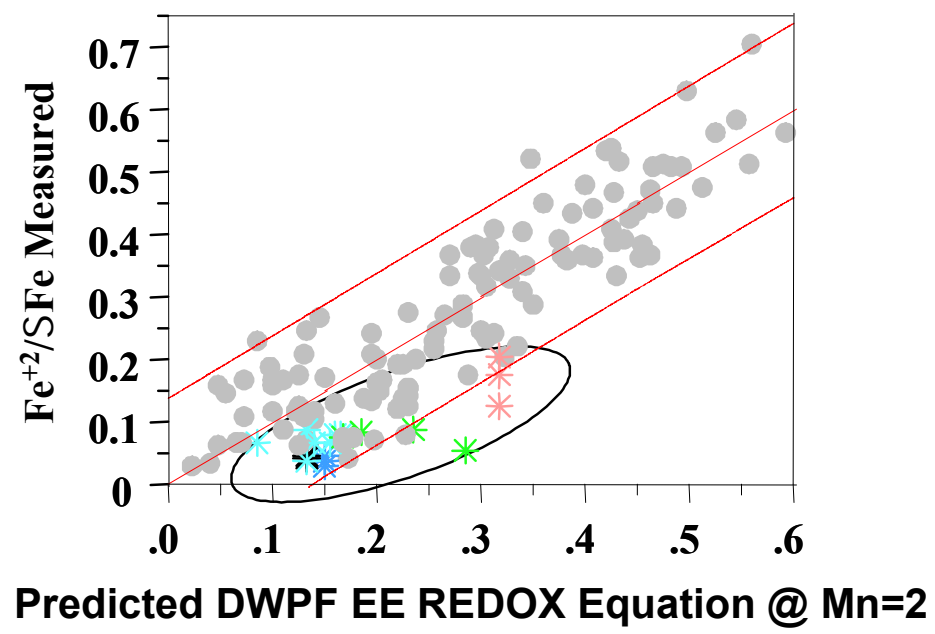

Figure 19. The SB4 REDOX data overlain on Equation 9, the 2003 DWPF EE REDOX Model [15] indicating the oxidized bias in the SB4 data to the 2003 REDOX model. The solid line represents the 2003 DWPF EE REDOX Model $\left(\mathrm{Fe}^{+2} / \Sigma \mathrm{Fe}=0.1942 \xi+0.191\right)$ and the dashed lines represent the Upper and Lower 95\% confidence limits so the slope of the line is 1.00 and the intercept is zero. The gray solid circles are the data used in the generation and validation of the 2003 DWPF EE REDOX model and plot. The stars are the SB4 crucible data that are superimposed for comparison.

The manganous ion, $\mathrm{Mn}^{+2}$, is the most stable aqueous oxidation state of manganese in solution but the +3 to +7 oxidation states can also occur [88]. $\mathrm{Mn}^{+2}$ can easily be oxidized in basic solutions to $\mathrm{Mn}^{+4}$, but the +3 state (manganic) is unstable, being easily reduced to $\mathrm{Mn}^{+2}$ or disproportionating to $\mathrm{Mn}^{+2}$ and $\mathrm{MnO}_{2}$ [88]. Likewise, $\mathrm{Mn}^{+6}$ (manganate) as $\mathrm{MnO}_{4}{ }^{2-}$ is stable only in very basic solutions and it disproportionates in acid into permanganate $\left(\mathrm{Mn}^{+7} \mathrm{O}_{4}{ }^{-}\right)$and $\mathrm{MnO}_{2}$. Thus only the $+2,+3$ and +7 states of $\mathrm{Mn}$ are significant in solution. However, the +4 state is stable as a solid, and oxidized +5 and +6 states can be stabilized by fusion reactions (see Section 6.5). 
Plotting of the data for the SB4 alternate reductant runs (sugar, oxalates, excess formic acid) that did not form metallic species ${ }^{\dagger}$ is shown in Figure 20 (top) and validates the terms for formic acid, nitric acid, and oxalate in Equation 9 and an electron transfer term developed in reference 15 for sugar, e.g. increased oxalate and increased sugar follow the slope of the model albeit biased toward the L95 since the manganese term is likely incorrect. The term for coal could not be validated as all the coal samples contained metallic species in the vicinity of the granular coarse coal particles that had been used during experimentation. During development of the 2003 EE REDOX model, fine coal had been found to be more reactive and was used preferentially in development of the model.

The validation of the alternate reduction terms using Equation 9 demonstrates that the SB4 data is biased to lower REDOX values than the SB3 and historic REDOX data when an EE of 2 is used for manganese. However, most of the SB4 data points do fall within the $95 \%$ confidence bands of the model when an EE of 2 is used for manganese. If a comparison of the alternate reductants is performed assuming a five EE transfer (assuming $\mathrm{Mn}^{+7} \rightarrow \mathrm{Mn}^{+2}$ ) for manganese, since $\mathrm{Mn}^{+2}$ and $\mathrm{Mn}^{+7}$ are the most reduced and most oxidized manganese species possible in a variety of Mn containing solutions [88] and solids, the alternate reductant terms fit Equation 9 with less bias (see Figure 20 bottom). For an EE transfer of five to be operative, $\mathrm{Mn}^{+7}$ is either being stabilized in the DWPF feed (discussed below) or during cold cap reactions (see Section $6.5)$.

Manganese is present in SRS sludges as $\mathrm{Mn}^{+4}$ or $\mathrm{Mn}^{+3}$ (e.g. $\mathrm{MnO}_{2}$ or $\mathrm{Mn}(\mathrm{OH})_{4}$ or $\mathrm{MnOOH}$ ) as discussed in Sections 2.2 and 2.4. During SB4 sludge simulant preparation, potassium permanganate $\left(\mathrm{KMnO}_{4}\right)$ was used [89] along with $\mathrm{Mn}^{+2}\left(\mathrm{NO}_{3}\right)_{2}$ and many other transition metal nitrates. During SRAT processing, it is believed that the $\mathrm{KMnO}_{4}$ is destroyed by reaction with the $\mathrm{Mn}^{+2}\left(\mathrm{NO}_{3}\right)_{2}$ and formic acid $(\mathrm{HCOOH})$ added which converts the $\mathrm{Mn}^{+2}\left(\mathrm{NO}_{3}\right)_{2}$ and $\mathrm{KMn}^{+7} \mathrm{O}_{4}$ to $\mathrm{Mn}^{+2} \mathrm{COOH}$ and $\mathrm{Mn}^{+4} \mathrm{O}_{2}$ [90]. The conversion of manganese in sludge simulant feed to $\mathrm{Mn}^{+2} \mathrm{COOH}$ was more efficient when a formic acid only flowsheet [32] was being used. Conversion has not been as complete since the formic acid/nitric acid flowsheet was implemented [14]. Therefore, at some point excess nitrates may overwhelm the SRAT reactions and stabilize permanganate as $\mathrm{KMn}^{+7} \mathrm{O}_{4}$ and/or $\mathrm{NaMn}^{+7} \mathrm{O}_{4}$ and/or $\mathrm{HMn}^{+7} \mathrm{O}_{4}$. This is one potential source of $\mathrm{Mn}^{+7}$ that could cause the EE term in the DWPF REDOX model for manganese to be five instead of two. However, $\mathrm{Mn}^{+7}$ in acid solution is normally reduced to $\mathrm{Mn}^{+2}$, while in strongly alkaline solutions it can be transformed to $\mathrm{Mn}^{+6}$ [91]. Since the SRAT products are acidic to neutral at the end of SRAT processing, it is highly unlikely that $\mathrm{Mn}^{+7}$ is present in the SRAT product.

* Full sugar and half sugar formed metallic nodules; full Fe oxalate had metallic species on the top surface only; all of the Ca oxalates had metallic species and were very inhomogeneous; the antifoam glasses all formed metallic nodules. 
WSRC-STI-2006-00066

Revision 0

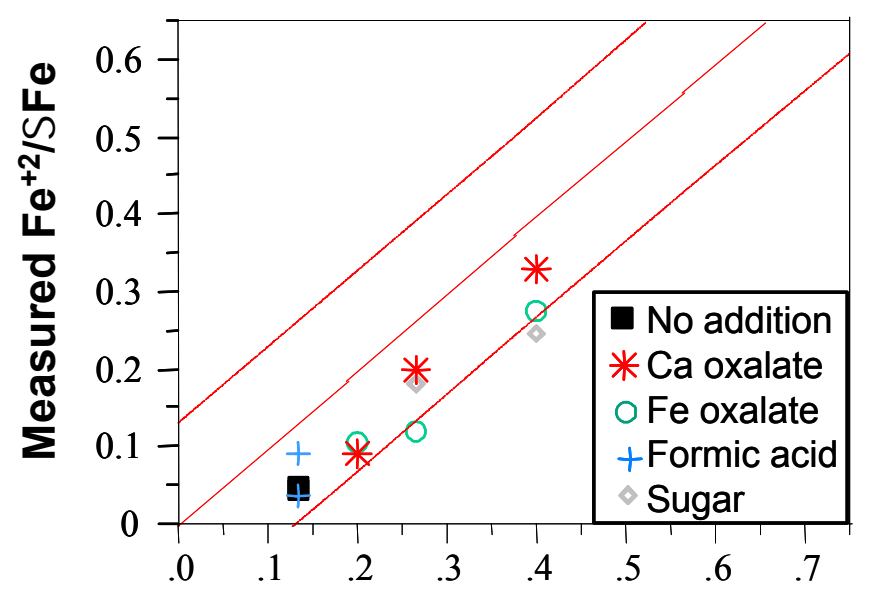

\section{Predicted 2003 EE REDOX Model @ Mn=2}

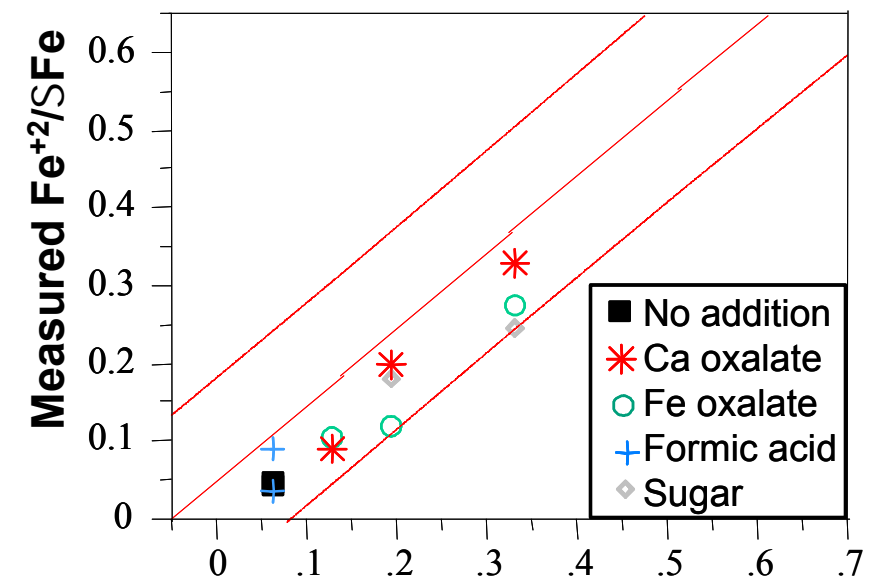

Predicted 2003 EE REDOX Model @ Mn=5

Figure 20. Validation of the Equation 9 terms for alternate reductants using various assumptions for the electron equivalents transfer of manganese. The solid lines represents the 2003 DWPF EE REDOX Model $\left(\mathrm{Fe}^{+2} / \Sigma \mathrm{Fe}=0.1942 \xi+0.191\right)$ and the dashed lines represent the Upper and Lower 95\% confidence limits. The slope of the regression in the upper figure is 1.00 and the intercept is zero, the slope of the regression in the lower figure is 1.00 and the intercept is 0.05 . 
To further test the five electron transfer hypothesis for $\mathrm{Mn}^{+7}$ reducing to $\mathrm{Mn}^{+2}$, an EE term for manganese of five was substituted into Equation 9 for all the SB3 and historic data. The plot generated, with the SB4 data overlain, is shown in

Figure 21; the slope and intercept of Equation 9 were not changed. This moves most of the SB4 data points within the upper and lower $95 \%$ confidence intervals. There is still bias in the data generated from the crucible experiments (indicated by the * in

Figure 21) but the SB4 SMRF campaigns indicated by the solid rectangles (purple in Figure 22) do not show this same bias. In addition, some of this bias can be minimized by refitting the SB4 data to a new regression along with the historic and SB3 data (see below) rather than just superimposing it on the correlation given in Equation 9.

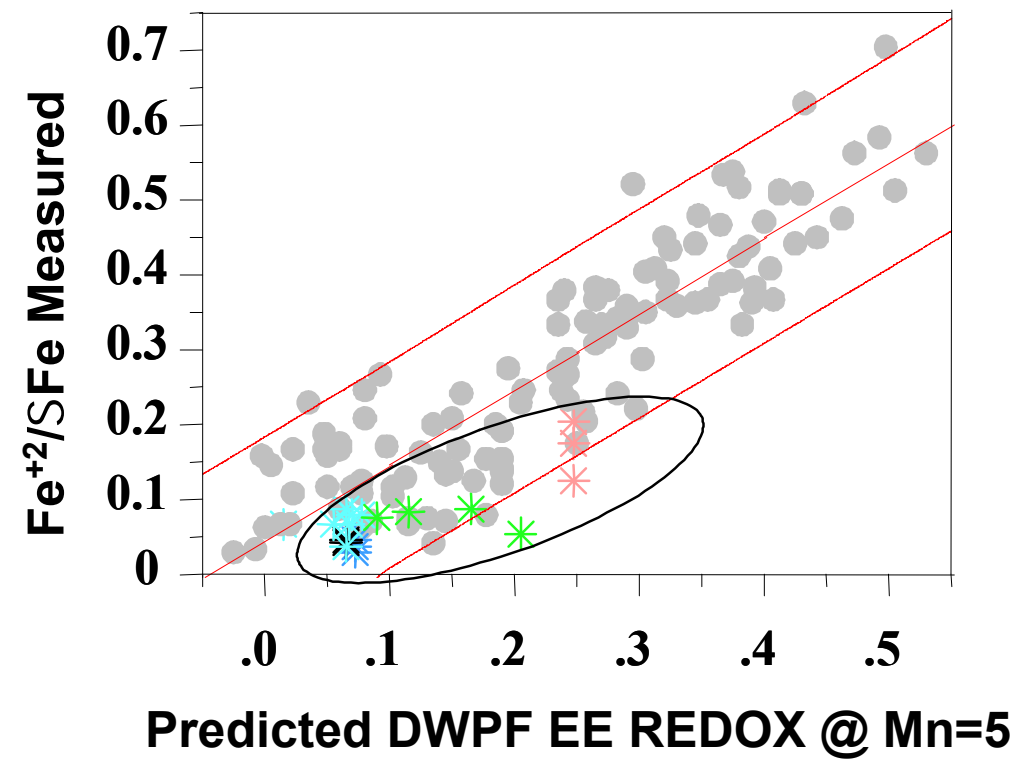

Figure 21. Fit of the SB4 REDOX data to Equation 9 using a five electron transfer for manganese instead of a two electron transfer. The solid lines represents the 2003 DWPF EE REDOX Model $\left(\mathrm{Fe}^{+2} / \Sigma \mathrm{Fe}=0.1942 \xi+0.191\right)$ and the dashed lines represent the Upper and Lower 95\% confidence limits. The slope of the line is 1.00 and the intercept is 0.05 . The gray solid circles are the data used in the generation and validation of the 2003 DWPF EE REDOX model and plot. The stars are the SB4 crucible data. 
Additional validation of the EE term of 5 for manganese was performed by performing a self fit of the historic, SB3 and SB4 data using JMP software. For this validation, the SB4 data from the solid alternative REDOX additives were omitted due to the inhomogeneous nature of the samples as discussed previously. The oxalate, formic acid, nitric acid, and coal terms were locked at the EE values given in Equation 9. Likewise, the intercept value of Equation 9, 0.1942, was locked. The slope and the manganese coefficient were allowed to be fit to the data. The self fit gave a manganese coefficient of -5.35 .

Therefore, the slope and intercept of the historic, SB3 and SB4 data were refit using the following number of electrons gained during reduction or lost during oxidation:

Equation 10

$$
\frac{F e^{2+}}{\Sigma F e}=f\left[\left(2[F]+4[C]+4\left[\mathrm{O}_{\mathrm{T}}\right]-5[N]-5[M n]\right) \frac{45}{T}\right]=f[\xi]
$$

where $f=$ indicates a function

$[\mathrm{F}]=$ formate $(\mathrm{mol} / \mathrm{kg}$ feed $)$

$[\mathrm{C}]=\operatorname{coal}$ (carbon) $(\mathrm{mol} / \mathrm{kg}$ feed $)$

$\left[\mathrm{O}_{\mathrm{T}}\right]=$ oxalate $_{\text {Total }}($ soluble and insoluble $)(\mathrm{mol} / \mathrm{kg}$ feed $)$

$[\mathrm{N}]=$ nitrate + nitrite $(\mathrm{mol} / \mathrm{kg}$ feed $)$

$[\mathrm{Mn}]=$ manganese $(\mathrm{mol} / \mathrm{kg}$ feed $)$

$\mathrm{T}=$ total solids $(\mathrm{wt} \%)$

$\xi=\left(2[F]+4[C]+4\left[\mathrm{O}_{\mathrm{T}}\right]-5[N]-5[M n]\right) \frac{45}{T}$

which assumes the following electron transfer equations for manganese instead of Equation 8:

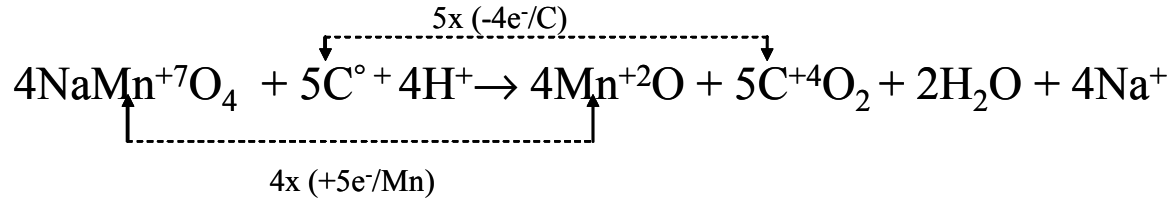

$$
\begin{aligned}
& 2 \mathrm{NaMn}^{+7} \mathrm{O}_{4}+5 \mathrm{HC}^{+2} \mathrm{OOH}+2 \mathrm{H}^{+} \rightarrow 2 \mathrm{Mn}^{+2} \mathrm{O}+5 \mathrm{C}^{+4} \mathrm{O}_{2}+6 \mathrm{H}_{2} \mathrm{O}+2 \mathrm{Na}^{+}
\end{aligned}
$$


A fit of an ordinary least squares regression to Equation 10 yielded an intercept of 0.2358 and a slope of 1.999 with an $\mathrm{R}^{2}$ of 0.81 and a RMSE of 0.0704 :

Equation 11

$$
\frac{F e^{+2}}{\sum F e}=0.2358+0.1999 \xi
$$

A plot of Equation 11 is shown in Figure 22 along with the DWPF, SMRF 2/3, SMRF 4, and Minimelter 2/3 validation data overlain.

It is unlikely that manganese as $\mathrm{Mn}^{+7}$ is coming in from the SRAT due to the presence of relatively large concentrations of the reductant formic acid in the SRAT. Therefore, experiments were designed to test the feed to glass conversion to elucidate the mechanisms by which $\mathrm{Mn}^{+7}$ was being stabilized (see Section 6.5).

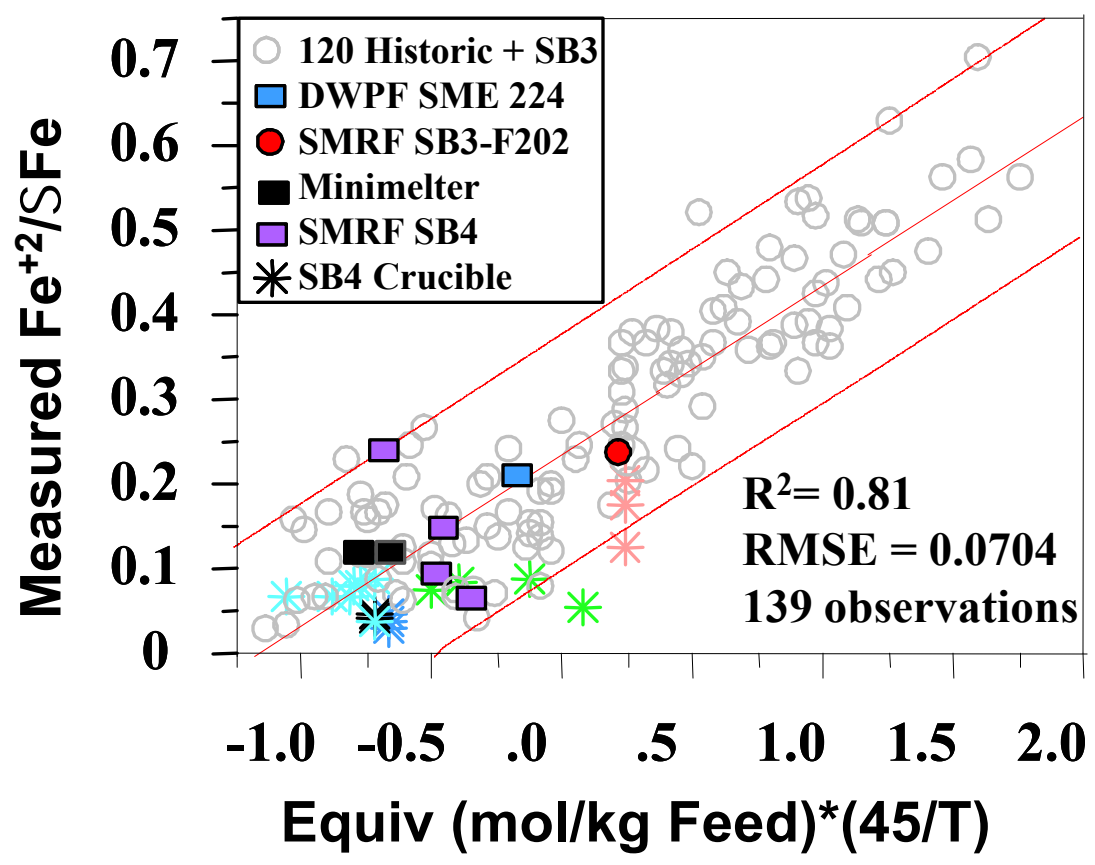

Figure 22. Fit of Equation 10 to the pooled historic, SB3 and SB4 REDOX data.

\subsection{Origin of $\mathrm{Mn}^{+7}$ Reactions During Melter Feed to Glass Conversion: SRAT Product or Cold Cap Molten Salt?}

Schreiber's EMF series [22] indicates that at the DWPF operational target where $\mathrm{Fe}^{+2} / \Sigma \mathrm{Fe}=0.09$ 0.33 that $99 \%$ of the manganese in glass will be present at $\mathrm{Mn}^{+2}$. Divalent manganese glass is colorless or weak yellow or brown $[92,93]$ when other multi-valent cations like Fe are absent. 
Trivalent $\mathrm{Mn}^{+3}$ can also exist in oxidized glasses (borates, silicates, and borosilicates) and $\mathrm{Mn}^{+3}$ is commonly used in commercial glasses (at $0.5-5 \mathrm{wt} \%$ ) as a purple or violet coloring agent [92, 93]: the product is known as amethyst glass due to the color. The violet color is not $\mathrm{Mn}^{+7}$ as the absorption spectra of violet glass and of $\mathrm{KMn}^{+7} \mathrm{O}_{4}$ in solution are dissimilar [93]. If the manganese source is added to glass as a colorizing agent as $\mathrm{Mn}^{+4} \mathrm{O}_{2}$ it starts to dissociate and liberate oxygen at $\sim 530^{\circ} \mathrm{C}$. If $\mathrm{KMn}^{+7} \mathrm{O}_{4}$ is used as a colorizing agent it starts to liberate oxygen at $\sim 240^{\circ} \mathrm{C}$ [93]. To ensure that the $\mathrm{Mn}^{+3}$ violet color is stabilized in a silicate glass with $5 \mathrm{wt} \%$ $\mathrm{Mn}^{+4} \mathrm{O}_{2}$, often $10 \mathrm{wt} \% \mathrm{KNO}_{3}-\mathrm{NaNO}_{3}$ is added as an oxidizing agent [93]. Above $700^{\circ} \mathrm{C}$ another reaction occurs where $\mathrm{Mn}^{+2} \mathrm{O}$, alkali, and oxygen can form the alkali manganates, e.g. $\mathrm{Mn}^{+6}$ and/or $\mathrm{Mn}^{+7}$ [92]. Alkali nitrites present in the batch are thought to assist this conversion as they decompose [92]. The $\mathrm{Mn}^{+7}$ converts back to $\mathrm{Mn}^{+3}$ or $\mathrm{Mn}^{+2}$ at higher temperatures $\left(>900^{\circ} \mathrm{C}\right)$ when the oxygen being liberated by the nitrites and nitrates is completely reacted and the glass is in equilibrium with the oxygen fugacity of the elevated temperatures in the melter [93]. High melting temperatures suppress $\mathrm{Mn}^{+3}$ in favor of $\mathrm{Mn}^{+2}$ [93], while alkali stabilizes $\mathrm{Mn}^{+3}$ as $(\mathrm{K}, \mathrm{Na}, \mathrm{Li}) \mathrm{Mn}^{+3} \mathrm{O}_{2}$ in the glass [94].

Alkali rich glasses, which are more basic, favor the manganic $\mathrm{Mn}^{+3}$ species [92,93]. In sodium borate melts, green manganates $(+6$ or +7$)$ are formed as soon as the ratio of $\mathrm{Na}_{2} \mathrm{O}: \mathrm{B}_{2} \mathrm{O}_{3}$ exceeds 2:1 [92]. The green color is transitory and disappears as the melt gets hotter in favor of $\mathrm{Mn}^{+3}$ or $\mathrm{Mn}^{+2}$.

Therefore, $\mathrm{Mn}^{+7}$ may be (1) entering the melter in the feed or (2) entering the melter as reduced $\mathrm{Mn}^{+2}$ which is subsequently converted by nitrite/nitrate oxygen evolution in the cold cap or melt pool to $\mathrm{Mn}^{+7}$ or converted by a transient molten salt phase in the cold cap to $\mathrm{Mn}^{+7}$. As the $\mathrm{Mn}^{+7}$ rich feed or cold cap product sinks into the melt pool, it reconverts into $\mathrm{Mn}^{+3}$ and ultimately to stable $\mathrm{Mn}^{+2}$ at the oxygen fugacities of the DWPF melter. This reconverting of $\mathrm{Mn}^{+7}$ to $\mathrm{Mn}^{+2}$ or $\mathrm{Mn}^{+3}$ liberates oxygen gas and creates foam.

\subsubsection{Identification of a Molten Salt Phase at $\leq 300^{\circ} \mathrm{C}$}

A series of sealed crucible studies were performed using the same sealed crucible methodology used for the REDOX testing and measurement of the historic, SB3 and SB4 feeds, e.g. Procedure L29-0052 Rev. 1. This method calls for heat treating the feed at $1150^{\circ} \mathrm{C}$ for one hour in a crucible sealed with nepheline gel using sufficient feed to generate approximately 30 grams of glass. In order to study the feed to glass conversion, and the possible existence of a molten salt phase, lower temperature heat treatments were performed in sealed crucibles for 1 hour and the samples air quenched to stop the reactions.

The feed to glass conversion was "stopped" at several intermediate temperatures, e.g. at $300^{\circ} \mathrm{C}$, $350^{\circ} \mathrm{C}, 500^{\circ} \mathrm{C}$, and $775^{\circ} \mathrm{C}$, after heat treatment for 1 hour (the same time interval used for the complete sludge to glass conversion at $1150^{\circ} \mathrm{C}$ ). This was done for SRAT batch SB4-32 mixed with Frit 418 and archived SB2/3 SME product made with Frit 202 for SMRF testing of SB2/3. The SB4-32 SRAT product formed a light phase and a darker phase in the crucible. The different colored phases were submitted for XRD separately. The lighter phase was found to contain more of the alumina rich phases, bayerite and gibbsite than the dark phase (Table 6). It 
is of note that the $\mathrm{SB} 2 / 3$ and the SB4 sludges when heat treated at $300^{\circ} \mathrm{C}, 350^{\circ} \mathrm{C}$, and $500^{\circ} \mathrm{C}$ all formed transient alkali carbonate phases, while iron carbonate phases had been identified in SB4 SRAT product dried at $110^{\circ} \mathrm{C}[72]$.

Unidentified peaks were evident in the SB4-32 SRAT product mixed with Frit 418 and heat treated at $300^{\circ} \mathrm{C}$ as shown in Figure 23 (top) by the dotted vertical lines. These peaks were missing in the sample heat treated at $500^{\circ} \mathrm{C}$ (Figure 23 middle). A second SB4-32 SRAT product was heat treated at $300^{\circ} \mathrm{C}$ without the addition of any frit (Figure 23 bottom). The same unidentified peaks were present but they were much more prominent since the sample analyzed was not diluted with any frit. The d-spacings in angstroms for the unidentified peaks are given in Table 7 along with tentative identification as a mixed alkali phase(s) of various sodium and potassium nitrates and nitrites $\left(\mathrm{NaNO}_{3}, \mathrm{KNO}_{3}, \mathrm{NaNO}_{2}, \mathrm{KNO}_{2}, \mathrm{~K}_{3} \mathrm{NO}_{3}\right)$. These unidentified peaks were not observed in the archived SB2/3 sample heat treated at $350^{\circ} \mathrm{C}$ (Figure 24). It is hypothesized that the molten salt phase may be more soluble in the SB2/3 high iron containing feeds than in the SB4 high alumina feeds or there is more alkali to stabilize higher nitrate concentrations.

The binary system between $\mathrm{NaNO}_{2}-\mathrm{NaNO}_{3}$ has a low melting eutectic at $226^{\circ} \mathrm{C}$ and the end member components melt at $284-309^{\circ} \mathrm{C}$ (Figure $25 \mathrm{left}$ ). The quaternary system $\mathrm{NaNO}_{2-}$ $\mathrm{NaNO}_{3}-\mathrm{KNO}_{2}-\mathrm{KNO}_{3}$ has various eutectics between $142-184^{\circ} \mathrm{C}$ (Figure 25 right). The reaction of sodium formate with molten $\mathrm{NaNO}_{3}$ or $\mathrm{NaNO}_{2}$ is reported [95] to be complete in $<1$ hour at $325^{\circ} \mathrm{C}$ but reactions of $\mathrm{NaNO}_{3}$ and $\mathrm{NaNO}_{2}$ with carbon or organic compounds are reported to form $\mathrm{Na}_{2} \mathrm{CO}_{3}$ in HLW melter cold caps [95]. Since $\mathrm{Na}_{2} \mathrm{CO}_{3}$ and the molten salts are observed in the XRD spectra of this study, it is likely that excess nitrate exists over the amount of carbon from formate and that this allows a separate molten salt phase to form. 
Table 6. Summary of Phases Formed During SB4 Feed to Glass Conversion in Sealed Crucibles

\begin{tabular}{|c|c|c|c|c|}
\hline Sample ID & $\begin{array}{l}\text { Temp } \\
\left({ }^{\circ} \mathrm{C}\right) / \text { Test }\end{array}$ & Major XRD Phases & $\begin{array}{l}\text { Minor XRD } \\
\text { Phases }\end{array}$ & $\%$ acid \\
\hline $\begin{array}{l}\text { SB4-1 to SB4- } \\
8 \\
{[72, p .31]}\end{array}$ & 110/SRAT & $\begin{array}{l}\mathrm{NaNO}_{3} \\
\mathrm{Al}(\mathrm{OH})_{3}(\text { bayerite }+ \text { gibbsite }) \\
\mathrm{NiO}\left(\text { not } \mathrm{Ni}(\mathrm{COOH})_{2} \text { as expected }\right) \\
\mathrm{FeOOH}\end{array}$ & & $130-160$ \\
\hline SB4-6 & 110/SRAT & As above $+\mathrm{Na}_{6} \mathrm{Al}_{6} \mathrm{Si}_{10} \mathrm{O}_{32}$ & & 140 \\
\hline SB4-7 and -8 & 110/SRAT & $\begin{array}{l}\text { As above }+\mathrm{Fe}_{2} \mathrm{O}_{3}+ \\
\mathrm{Fe}\left(\mathrm{CO}_{3}\right) \text {-siderite (isostructural with } \\
\mathrm{Mn}\left(\mathrm{CO}_{3}\right)\end{array}$ & & $150-160$ \\
\hline $\begin{array}{l}\text { SB4-32-38 } \\
\text { (frit 418) }\end{array}$ & $\begin{array}{l}\text { 300/Sealed/ } \\
\text { Light part }\end{array}$ & $\begin{array}{l}\mathrm{SiO}_{2} \\
\mathrm{Al}(\mathrm{OH})_{3} \text { and } \mathrm{AlOOH} \text { (bayerite }+ \\
\text { gibbsite) } \\
\mathrm{Na}_{2} \mathrm{CO}_{3}\left(\mathrm{H}_{2} \mathrm{O}\right) \text { (Thermonatrite) }\end{array}$ & & 130 \\
\hline $\begin{array}{l}\text { SB4-32-38 } \\
\text { (frit 418) }\end{array}$ & $\begin{array}{l}\text { 300/Sealed/ } \\
\text { Dark part }\end{array}$ & $\begin{array}{l}\mathrm{SiO}_{2} \\
\mathrm{Na}_{2} \mathrm{CO}_{3}\left(\mathrm{H}_{2} \mathrm{O}\right) \text { (Thermonatrite) }\end{array}$ & & 130 \\
\hline $\begin{array}{l}\text { SB4-32-38 } \\
\text { (frit 418) }\end{array}$ & 500/Sealed & $\begin{array}{l}\mathrm{SiO}_{2} \\
\text { Spinel }\left(\text { maybe } \mathrm{Fe}^{+2} \mathrm{Fe}^{+3} \mathrm{O}_{4}\right) \\
\text { Trona }\left(\mathrm{Na}_{3} \mathrm{H}\left(\mathrm{CO}_{3}\right)_{2}\left(\mathrm{H}_{2} \mathrm{O}\right)_{2}\right)\end{array}$ & $\begin{array}{l}\mathrm{Al}(\mathrm{OH})_{3} \\
\text { (Bayerite) } \\
\mathrm{NaAlSiO}_{4} \\
\text { (nepheline) }\end{array}$ & 130 \\
\hline $\begin{array}{l}\text { SB4-32-38 } \\
\text { (frit 418) }\end{array}$ & 775/Sealed & $\begin{array}{l}\mathrm{NiFe}_{2} \mathrm{O}_{4} \text { (trevorite) } \\
\mathrm{NaAlSiO}_{4} \text { (nepheline) } \\
\mathrm{NaFe}^{+3}\left(\mathrm{SiO}_{3}\right)_{2} \text { (acmite) } \\
\mathrm{Al}_{14} \mathrm{Si}_{0.3} \mathrm{O}_{27} \text { (aluminosilicate) }\end{array}$ & $\begin{array}{l}\mathrm{NiO} \\
\text { (Burnessite) }\end{array}$ & 130 \\
\hline $\begin{array}{l}\text { SB4-32 } \\
\text { (no frit) }\end{array}$ & 300 & $\begin{array}{l}\mathrm{SiO}_{2} \\
\mathrm{Al}(\mathrm{OH})_{3} \text { and } \mathrm{AlOOH} \text { (bayerite }+ \\
\text { gibbsite) } \\
\mathrm{Na}_{2} \mathrm{CO}_{3}\left(\mathrm{H}_{2} \mathrm{O}\right) \text { (Thermonatrite) } \\
\end{array}$ & & \\
\hline $\begin{array}{l}\text { SB2/SB3 } \\
\text { SMRF 0155 } \\
\text { and SMRF } \\
\text { 0159-Frit } 202 \\
\end{array}$ & $350 /$ Sealed & $\begin{array}{l}\mathrm{Fe}_{2} \mathrm{O}_{3} \\
\left(\mathrm{Ni}_{3}, \mathrm{Fe}\right) \mathrm{Fe}_{2} \mathrm{O}_{4} \\
\mathrm{Na}_{2} \mathrm{Mg}\left(\mathrm{CO}_{3}\right)_{2}\end{array}$ & $\begin{array}{l}\mathrm{AlOOH} \\
\mathrm{SiO}_{2}\end{array}$ & \\
\hline $\begin{array}{l}\text { SB2/SB3 } \\
\text { SMRF 0155 } \\
\text { and SMRF } \\
0159-\text { Frit } \\
202\end{array}$ & 500/Sealed & $\begin{array}{l}\mathrm{Fe}_{2} \mathrm{O}_{3} \\
(\mathrm{Ni}, \mathrm{Fe}) \mathrm{Fe}_{2} \mathrm{O}_{4}\end{array}$ & $\mathrm{SiO}_{2}$ & \\
\hline
\end{tabular}


Table 7. Comparison of the d-spacings of Unidentified Phases in SB4-32 with Various Nitrate and Nitrite Compounds.

\begin{tabular}{|c|c|c|c|c|c|c|}
\hline $\begin{array}{c}\text { d-spacing } \\
(\AA) \\
\text { SB4-32 } \\
\text { No frit }\end{array}$ & $\begin{array}{c}\text { d-spacing } \\
(\AA) \\
\text { SB4-32 } \\
\text { Frit 418 }\end{array}$ & $\begin{array}{c}\text { d-spacing } \\
(\AA) \\
\mathrm{NaNO}_{3} \\
(\mathrm{PDF} \# 36- \\
1474)\end{array}$ & $\begin{array}{c}\text { d-spacing } \\
(\AA) \\
\mathrm{NaNO}_{2} \\
(\mathrm{PDF} \# 6- \\
392\end{array}$ & $\begin{array}{c}\text { d-spacing } \\
(\AA) \\
\mathrm{K}_{3} \mathrm{NO}_{3} \\
(\mathrm{PDF} \# 36- \\
\mathbf{1 1 8 8})\end{array}$ & $\begin{array}{c}\text { d-spacing } \\
(\AA) \\
\mathrm{KNO}_{2} \\
(\mathrm{PDF} \# 30- \\
966)\end{array}$ & $\begin{array}{c}\text { d-spacing } \\
(\AA) \\
\text { KNO }_{3} \\
\text { (PDF \#11- } \\
\text { 30) }\end{array}$ \\
\hline 3.70 & 3.70 & & & & & 3.75 \\
\hline 2.96 & 3.03 & 3.04 & 2.98 & 3.01 & 3.00 & 3.08 \\
\hline 2.88 & 2.85 & 2.8 & 2.79 & & & 2.8 \\
\hline 2.63 & 2.63 & & & 2.61 & 2.69 & 2.69 \\
\hline 2.57 & & & 2.56 & & 2.57 & 2.53 \\
\hline 2.50 & & & & & & 2.48 \\
\hline 1.85 & 1.84 & 1.89 & & 1.84 & 1.9 & 1.87 \\
\hline
\end{tabular}


WSRC-STI-2006-00066

Revision 0

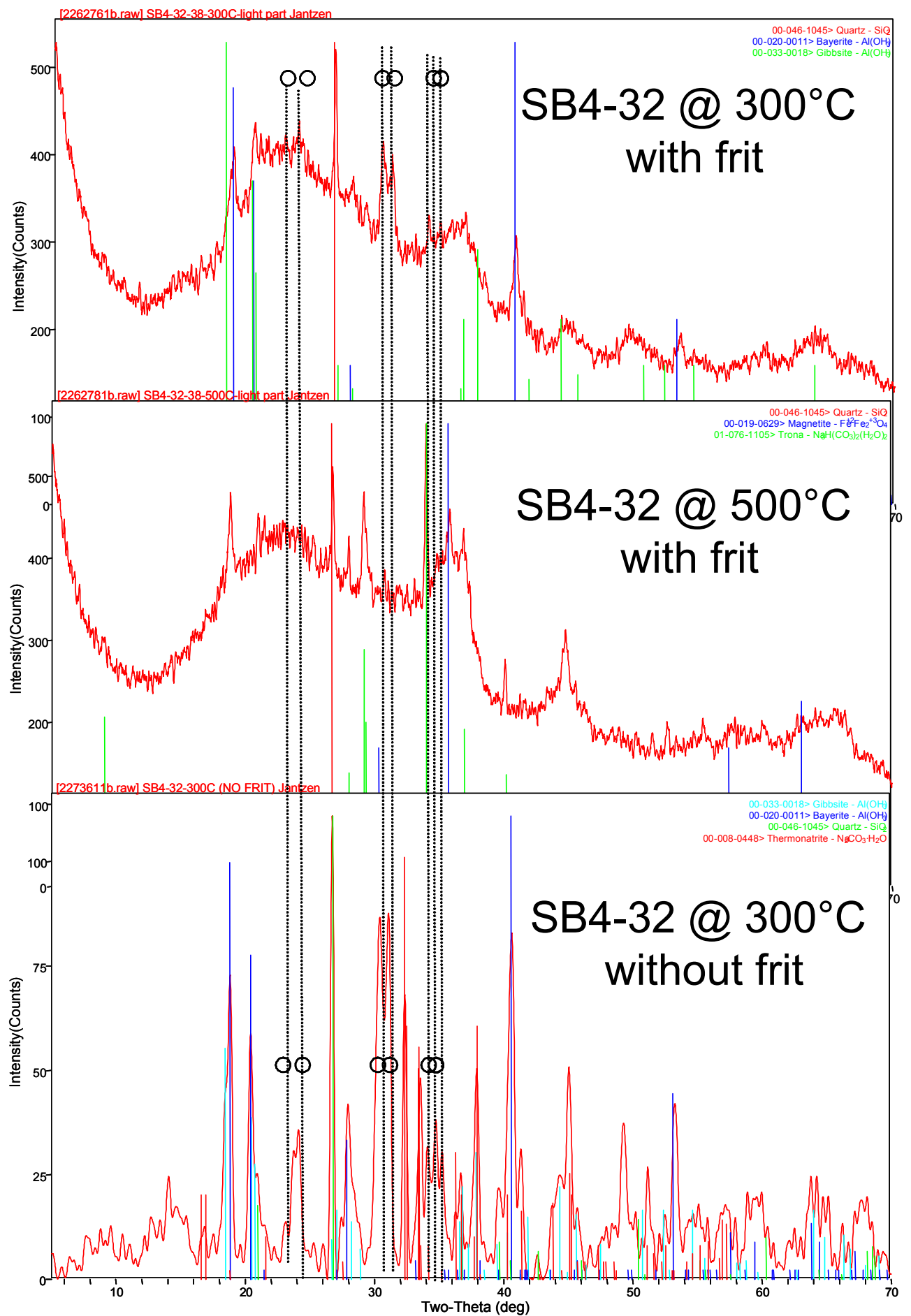

Figure 23. X-ray diffraction spectra of SB4-32 during the sludge to glass conversion between $300-500^{\circ} \mathrm{C}$ and SB4-32 conversion at $300^{\circ} \mathrm{C}$ in the absence of frit. 
WSRC-STI-2006-00066

Revision 0

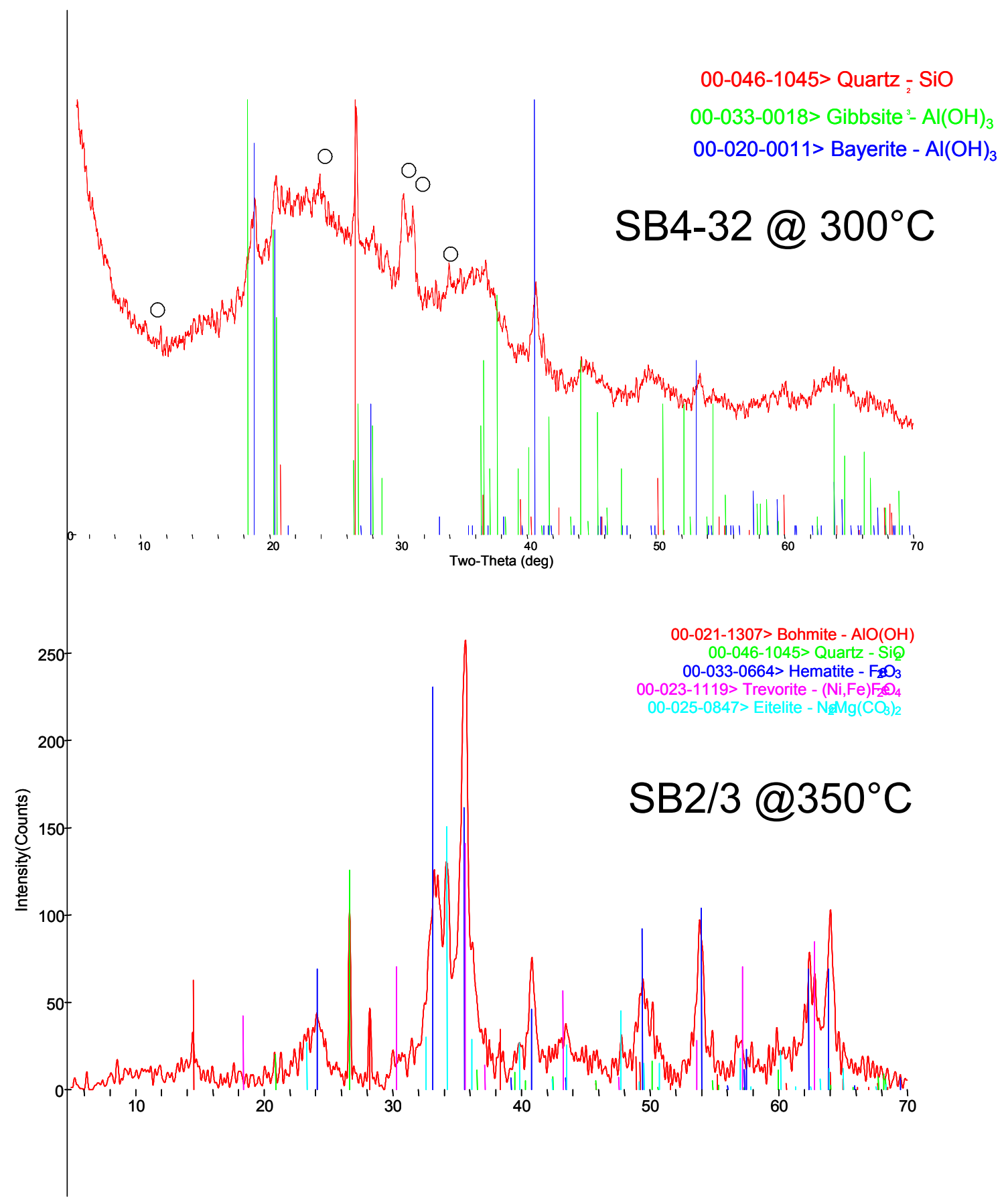

Figure 24. Comparison of SB4-32 melter feed at $300^{\circ} \mathrm{C}$ to conversion of SB2/3 melter feed at $350^{\circ} \mathrm{C}$. Bragg reflections belonging to a mixed alkali nitrate-nitrite phase appear only in SB4 feeds. 
$\mathrm{NaNO}_{2}-\mathrm{NaNO}_{3}$

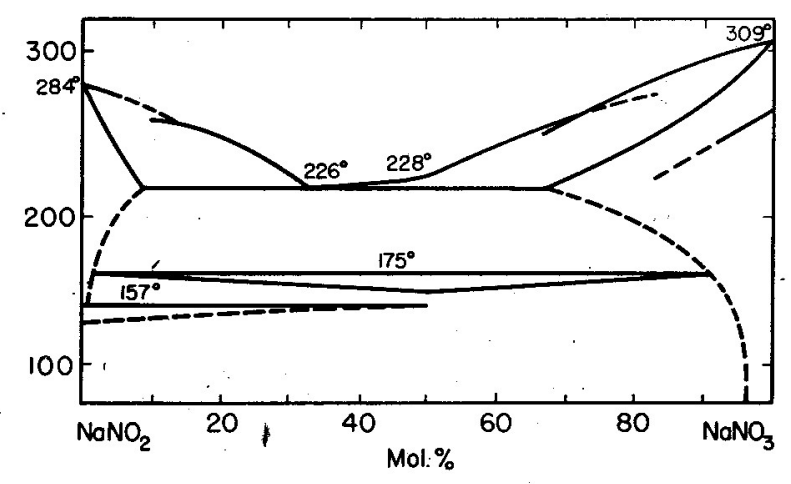

FIG. 1081.-System $\mathrm{NaNO}_{2}-\mathrm{NaNO}_{3}$.

A. G. Bergman, S. I. Berul, and I. N. Nikonova, Izvest. Sektora Fiz.-Khim. Anal., Inst. Obshcheĭ Neorg. Khim., Akad. Nauk S.S.S.R., 23, 183 (1953).

\section{$\mathrm{KNO}_{2}-\mathrm{NaNO}_{2}-\mathrm{KNO}_{3}-\mathrm{NaNO}_{3}$}

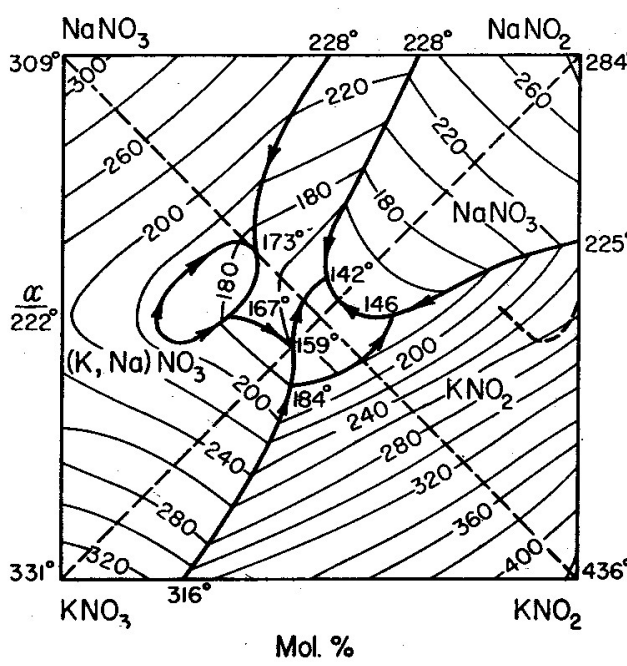

FIG. 1083.-System $\mathrm{KNO}_{2}-\mathrm{NaNO}_{2}-\mathrm{KNO}_{3}-\mathrm{NaNO}_{2}$.

S. I. Berul and A. G. Bergman, Irvest. Sektora Fiz.-Khim. Anal.. Inst. Obshchei Neorg. Khim., Akad. Nauk S.S.S.R. 25, 233 (1954).

Figure 25. Phase equilibria of a mixed molten salt phase.

\subsubsection{Stabilization of $\mathrm{Mn}^{+7}$ by a Molten Salt Phase in the Cold Cap}

Manganese oxides are not known above the oxidation state of +4 , e.g. $\mathrm{MnO}_{2}$ [91]. However, alkali manganates salts with manganese in the +5 or +6 sate are known. The manganates salts are formed by fusion of $\mathrm{MnO}_{2}$ and a large excess of alkali in the presence of an oxidizing agent such as potassium nitrate, sodium nitrate, or atmospheric oxygen. Manganese +6 can further disproportionate to manganese +7 and manganese +2 [91] in the presence of water in neutral or acidic solutions.

Manganese +5 as alkali oxo compounds $\left(\mathrm{MnO}_{4}{ }^{-3}\right)$ are stabilized in molten $\mathrm{NaNO}_{2}$ at $300^{\circ} \mathrm{C}$ by $\mathrm{O}_{2}{ }^{-2} . \mathrm{Mn}^{+7}$ has been shown to be semistable in $(\mathrm{K}, \mathrm{Li}) \mathrm{NO}_{3}$ melts and in $(\mathrm{K}, \mathrm{Na}) \mathrm{NO}_{3}$ melts [96]. In (K,Na) $\mathrm{NO}_{3}$ melts, the $\mathrm{Mn}^{+7}$ (as alkali $\mathrm{MnO}_{4}^{-}$) ion slowly decomposed to $\mathrm{Mn}^{+6}$ (as $\mathrm{MnO}_{4}{ }^{-2}$ ) and to $\mathrm{MnO}_{2}$. Decomposition of potassium $\mathrm{Mn}^{+7}$ oxo compounds to mixtures of $\mathrm{Mn}^{+6}, \mathrm{Mn}^{+5}$, and $\mathrm{Mn}^{+4}$ have been reported by Ryan [95] at temperatures between $240-300^{\circ} \mathrm{C}$ followed by decomposition of $\mathrm{Mn}^{+6}$ to $\mathrm{Mn}^{+5}$ and $\mathrm{Mn}^{+3}$ at $640-680^{\circ} \mathrm{C}$, followed by decomposition of $\mathrm{Mn}^{+5}$ to $\mathrm{Mn}^{+3}$ at $850-1100^{\circ} \mathrm{C}$. Ryan also reports that $\mathrm{Na}_{2} \mathrm{O}_{2}$ in $\mathrm{NaNO}_{2}$ at $500^{\circ} \mathrm{C}$ can stabilize sodium $\mathrm{Mn}^{+5}$ oxo complexes at $500^{\circ} \mathrm{C}$ and that the presence of $\mathrm{Na}_{2} \mathrm{CO}_{3}$ in a melt stabilizes $\mathrm{Mn}^{+5}$ complexes at $700-800^{\circ} \mathrm{C}$. Lastly, Ryan states that in alkaline nuclear waste glass feeds having alkali nitrate and/or nitrite, oxidation to manganates (probably $\mathrm{Mn}^{+6}$ or higher) can be expected to occur at low temperatures beginning at $\sim 170^{\circ} \mathrm{C}$ [95]. Thus there are many paths by which the higher oxidation states of manganese may get stabilized in the DWPF melter cold cap by various molten salt reactions and liberation of oxygen by decomposition of nitrates. 
WSRC-STI-2006-00066

Revision 0

\subsubsection{Verification of Oxidized Manganese Species by SB4 Soluble Supernate Components}

A set of experiments were designed to demonstrate that the soluble nitrates in the SB4 supernates were causing manganese oxidation at and below the melt temperature. These tests were designed to demonstrate that at some point the amount of oxidants in the SB4 feeds overwhelms the reductant (formic acid).

First a set of glass standards was made with solutions of $\mathrm{Mn}^{+2}$ chloride $\left(\mathrm{MnCl}_{2}\right), \mathrm{Mn}^{+2}$ nitrate $\left(\mathrm{Mn}\left(\mathrm{NO}_{3}\right)_{2}\right), \mathrm{MnCl}_{2}$ plus $\mathrm{NaCOOH}$ (no $\mathrm{MnCOOH}$ was available), $\mathrm{Mn}^{+4} \mathrm{O}_{3}, \mathrm{KMn}^{+7} \mathrm{O}_{4}$. The solutions were formulated to $0.15 \mathrm{M}$ manganese (the same as the SB4 SRAT feeds). The $\mathrm{NaCOOH}$ was formulated to $1 \mathrm{M} \mathrm{COOH}$ about the same range as the SB4 SRAT feeds. Soluble $\mathrm{Mn}^{+4}$ was not available so solid $\mathrm{MnO}_{2}$ was dissolved in $\mathrm{HCl}$. This likely caused $\mathrm{MnCl}_{2}$ to form and liberate excess $\mathrm{O}_{2}$ so the $\mathrm{Mn}^{+4}$ solution was actually an $\mathrm{Mn}^{+2}$ solution. The nitrate was formulated at $0.15 \mathrm{M}$ since the concentration was the same as the manganese. One weight percent of each solution was mixed with Frit 418 and subjected to the sealed REDOX crucible tests at $1100^{\circ} \mathrm{C}$ for 1 hour, e.g. Procedure L29-0052 Rev. 1. Figure 26 indicates that the $\mathrm{Mn}^{+2}$ solutions did not change the REDOX of Mn in the glass, all the glasses remained clear thereby colorimetrically indicating the presence of $\mathrm{Mn}^{+2}$ in the glass. The $\mathrm{Mn}^{+2}$ nitrate and the $\mathrm{KMn}^{+7} \mathrm{O}_{4}$ solution turned the frit purple indicating that oxidation had occurred and oxidized the $\mathrm{Mn}^{+2}$ from the nitrate to $\mathrm{Mn}^{+3}$ in the glass and reduced the $\mathrm{Mn}^{+7}$ in the $\mathrm{KMnO}_{4}$ to $\mathrm{Mn}^{+3}$ in the glass. Note also the original surface of the frit plus solution in the nitrate and permanganate crucibles indicating that foam was generated as the $\mathrm{Mn}$ nitrate and the $\mathrm{Mn}^{+7}$ decomposed.

The same experiments were performed with combinations of the $\mathrm{MnCl}_{2}$ plus $\mathrm{NaCOOH}$ solution and $\mathrm{Mn}\left(\mathrm{NO}_{3}\right)_{2}$ solutions were mixed with Frit 418 to see at what combinations of oxidizers (Mn and $\mathrm{NO}_{3}$ ) and reductants would stabilize $\mathrm{Mn}^{+3}$ in the resulting glass instead of $\mathrm{Mn}^{+2}$. Figure 27 indicates that at $\geq 1.5$ times the amount of $\mathrm{Mn}\left(\mathrm{NO}_{3}\right)_{2}$ in weight percent over $\mathrm{MnCl}_{2}$ in the presence of $1 \mathrm{M}$ formate, the nitrate overwhelmed the reductants in the frit and oxidized the Mn in the glass to $\mathrm{Mn}^{+3}$. The experiments were repeated at $750^{\circ} \mathrm{C}$ (Figure 28) which showed that the mechanism was already operational at this temperature at $\geq 1.25$ times the amount of $\left.\mathrm{Mn}_{(\mathrm{NO}}\right)_{2}$ in weight percent over $\mathrm{MnCl}_{2}$ in the presence of $1 \mathrm{M}$ formate. The lowest manganese concentration in Figure 28 is the 1:1 mixture of manganese nitrate and manganese chloride/formate solution and the highest is the 2:1 mixture. Note that the manganese and formate concentrations in Figure 29 span the concentrations in the SB4 feeds while the nitrate concentrations are much lower. The oxidants begin to really overwhelm the reductants at $\sim 2: 1$ $\mathrm{Mn}^{+2}$ nitrate to $\mathrm{Mn}^{+2}$ chloride/formate.

In addition, the SB4 SRAT and SME products were centrifuged and the same amount of supernate as used in the manganese reference solution tests was mixed with Frit 418. The same sealed crucible tests were performed at $1150^{\circ} \mathrm{C}$ for 1 hour. While the glasses made with the SB4-32 and SB4-41 supernate remained clear (Figure 30) indicating that any manganese in the supernate was present at $\mathrm{Mn}^{+2}$, it should be noted that these glasses made with this feed were oxidized (Table 5). SB4-32 had no soluble Mn in the supernates, but SB4-41 had 51\% soluble manganese. The SB4-48 supernate turned the frit dark purple (Figure 30) indicating highly oxidizing conditions, and SB4-51/52 turned the frit a green yellow (Figure 30), which could be 
indicative of $\mathrm{Mn}^{+5}$ or $\mathrm{Ni}$ in the supernate although the SMRF studies on this run indicated the glass was reducing and the $\%$ soluble $\mathrm{Mn}$ in the supernate was only $11 \%$.

Lastly, if one uses the colorimetric results shown in Figure 27 and solves the L95 of Equation 11 $\left(\left[\mathrm{Fe}^{+2} / \Sigma \mathrm{Fe}\right]_{\mathrm{L} 95}=0.1836+0.1999 \xi\right)$ at the minimum REDOX modeled, e.g. $0.03 \mathrm{Fe}^{+2} / \Sigma \mathrm{Fe}$, for the manganese molar concentrations used in these five experiments $(0.15 \mathrm{M})$, the color change from clear to purple (Figure 31) corresponds to an EE value of -0.60 because only the nitrate and formate varied in molarity. Likewise, if one solves the L95 at the minimum REDOX to prevent foaming, e.g. $0.09 \mathrm{Fe}^{+2} / \Sigma \mathrm{Fe}$, at the $0.15 \mathrm{M}$ manganese concentrations tested, the color change occurs at an EE value of zero when the effects of the formate and nitrate are equivalent, e.g. $1 \mathrm{~F}: 2.5 \mathrm{~N}$ as indicated in Equation 11.

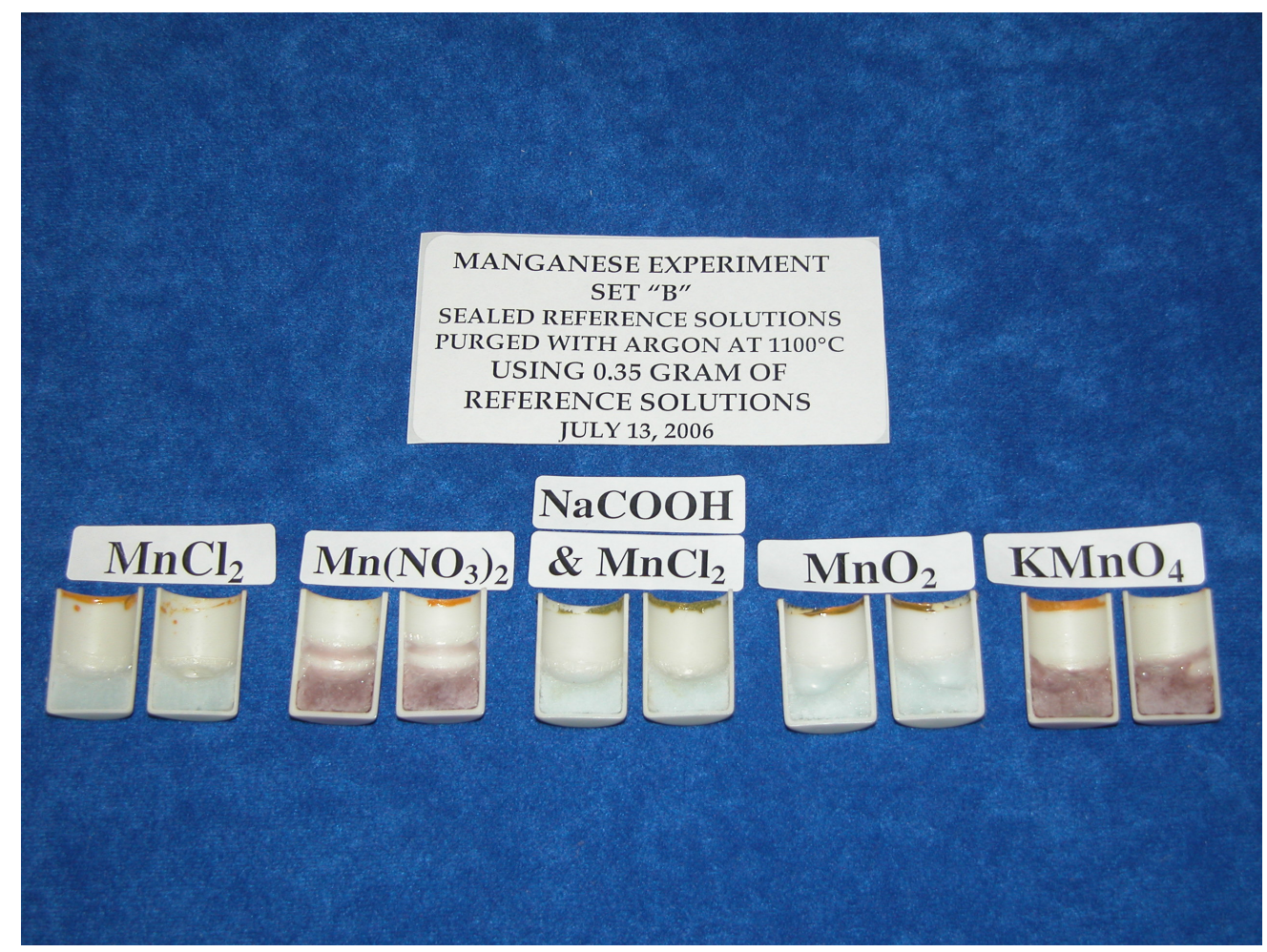

Figure 26. Reference glasses made with $\mathrm{Mn}^{+2}, \mathrm{Mn}^{+4}$ and $\mathrm{Mn}^{+7}$ solutions. 


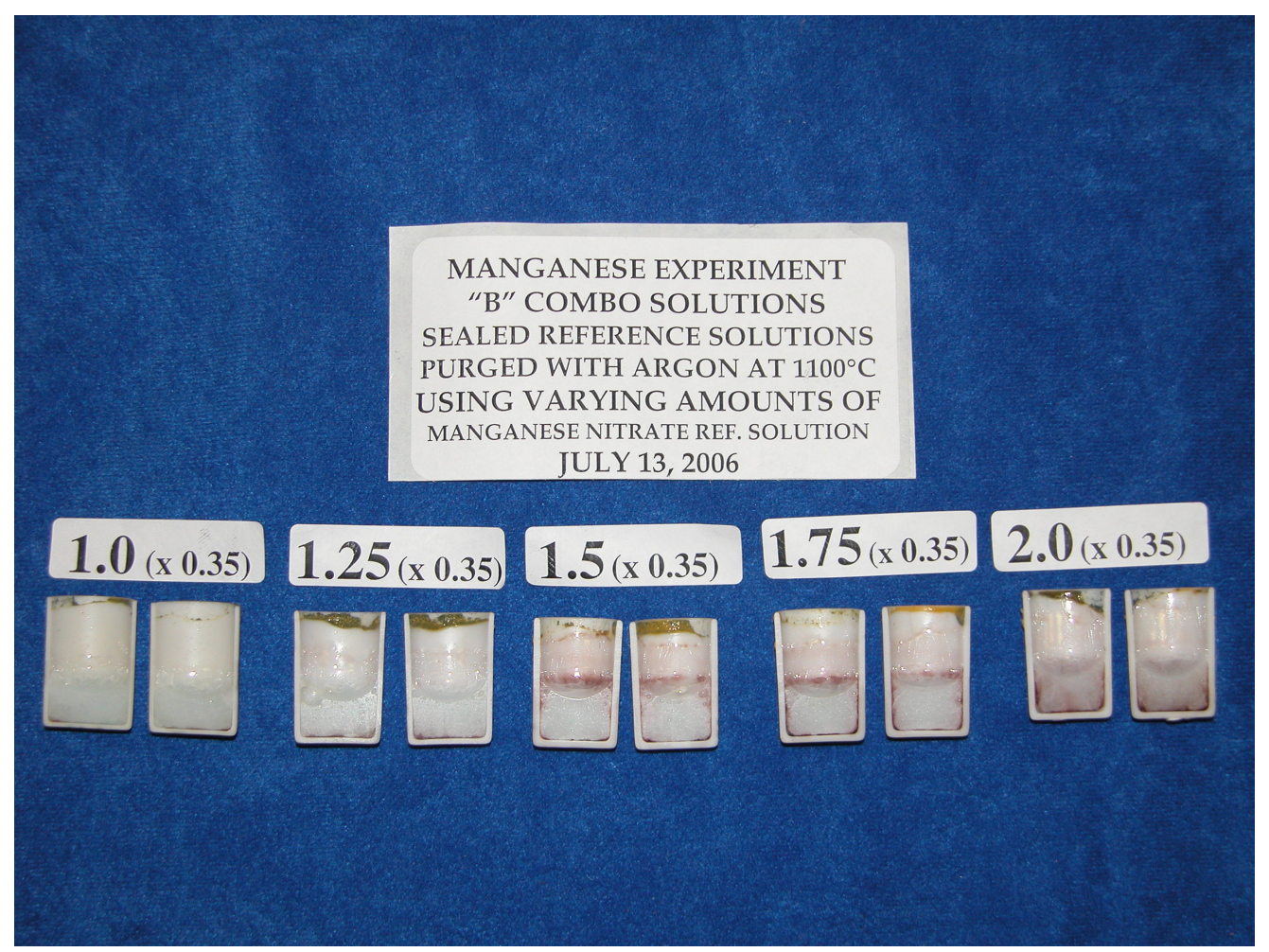

Figure 27. Test glasses made with varying amounts of nitrate and formate and $\mathrm{Mn}^{+2} \mathrm{Cl}_{2}$.

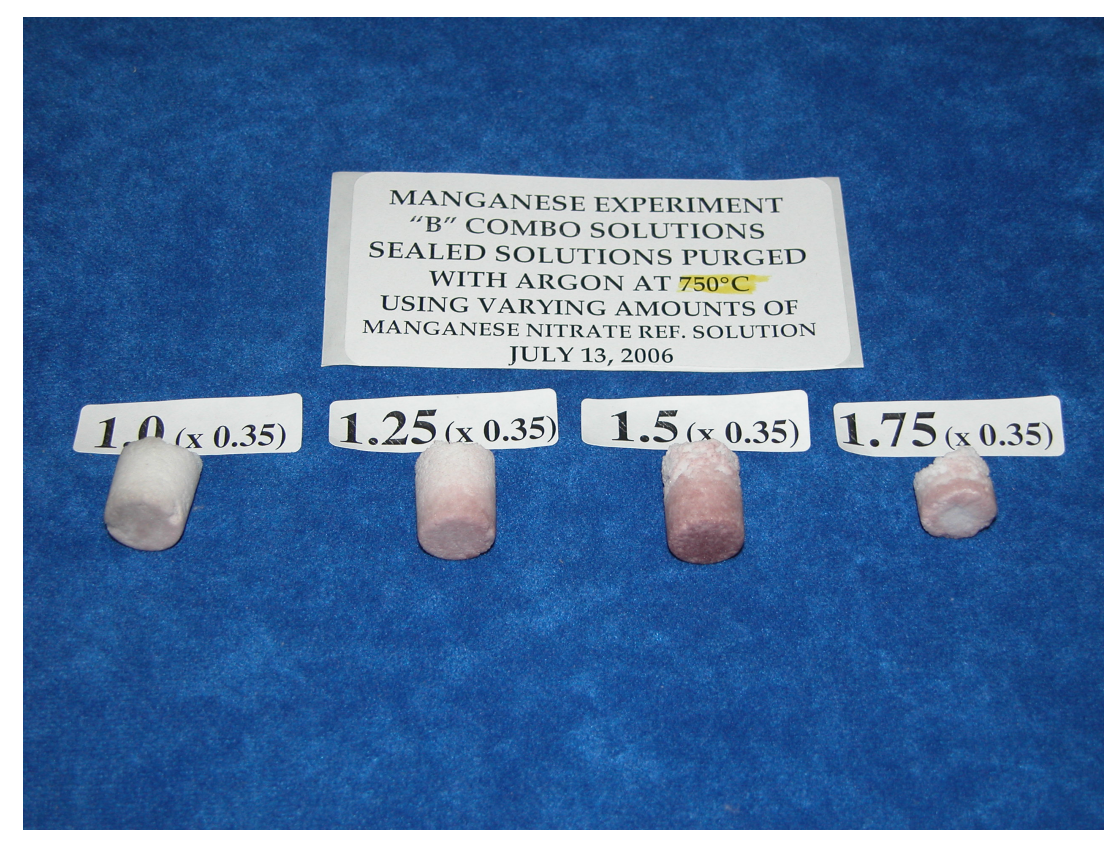

Figure 28. Test glasses made with varying amounts of nitrate and formate and $\mathrm{Mn}^{+2} \mathrm{Cl}_{2}$. 


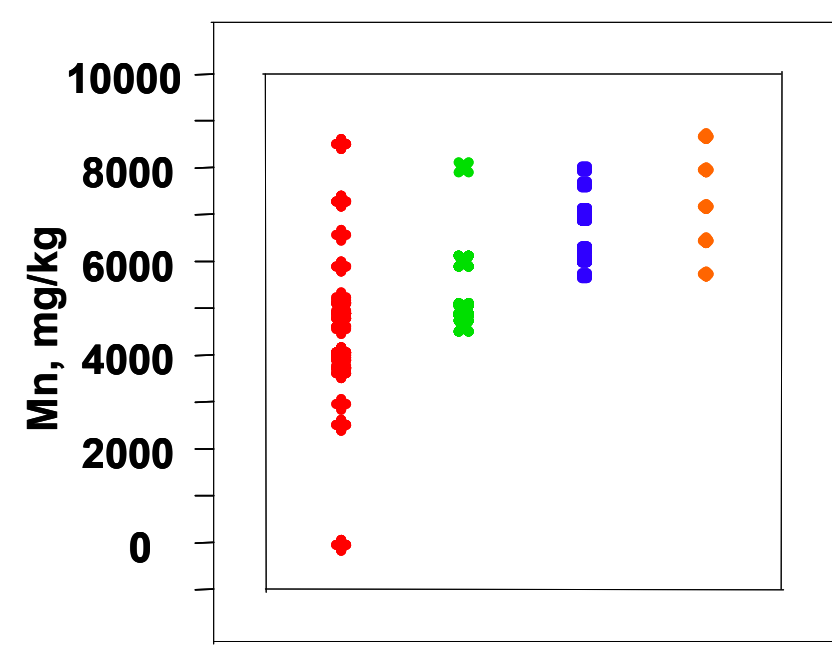

SB3 HISTORIC SB4 FRIT

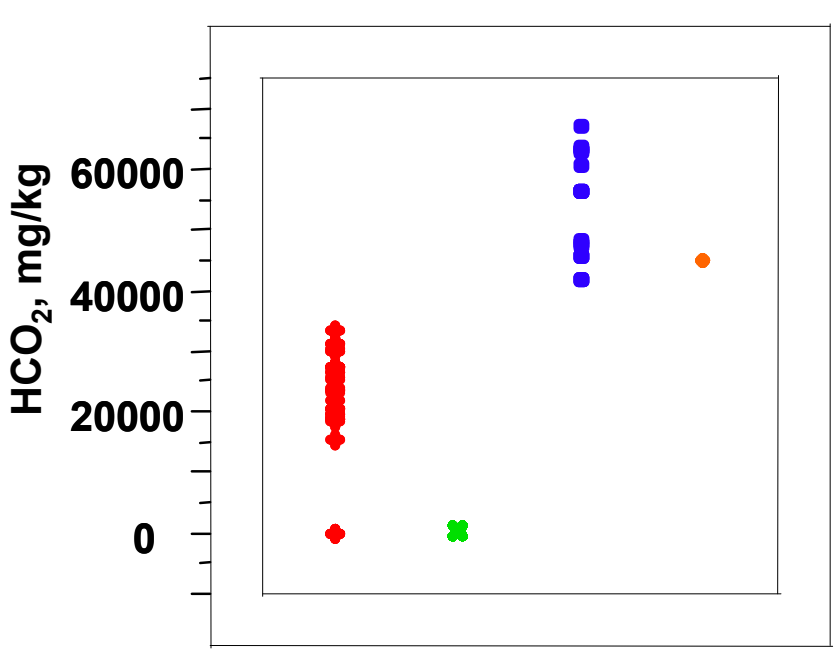

SB3 HISTORIC SB4 FRIT

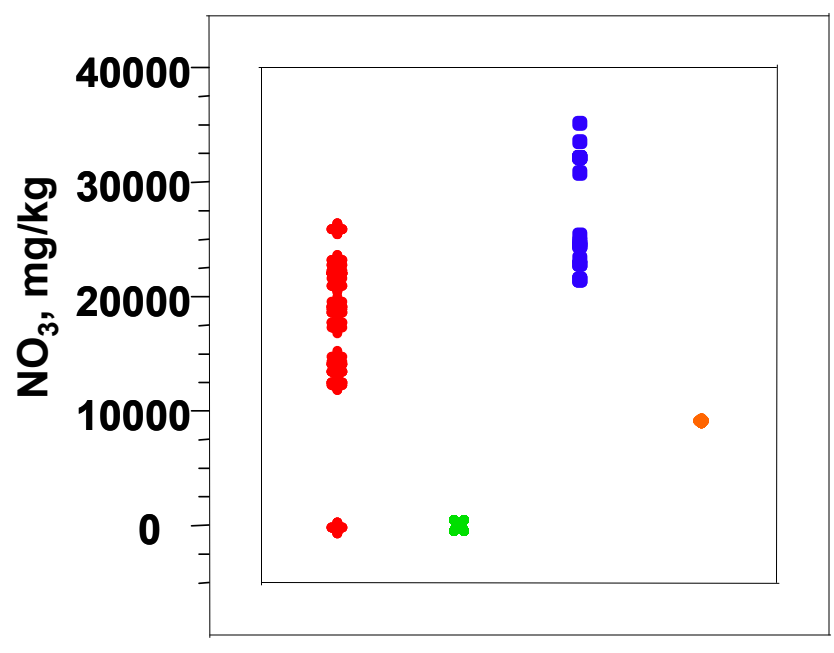

SB3 HISTORIC SB4 FRIT

Figure 29. Relative concentrations of the manganese, formate and nitrate in the colorimetric frit experiments compared to historic, SB3 and SB4 testing. 


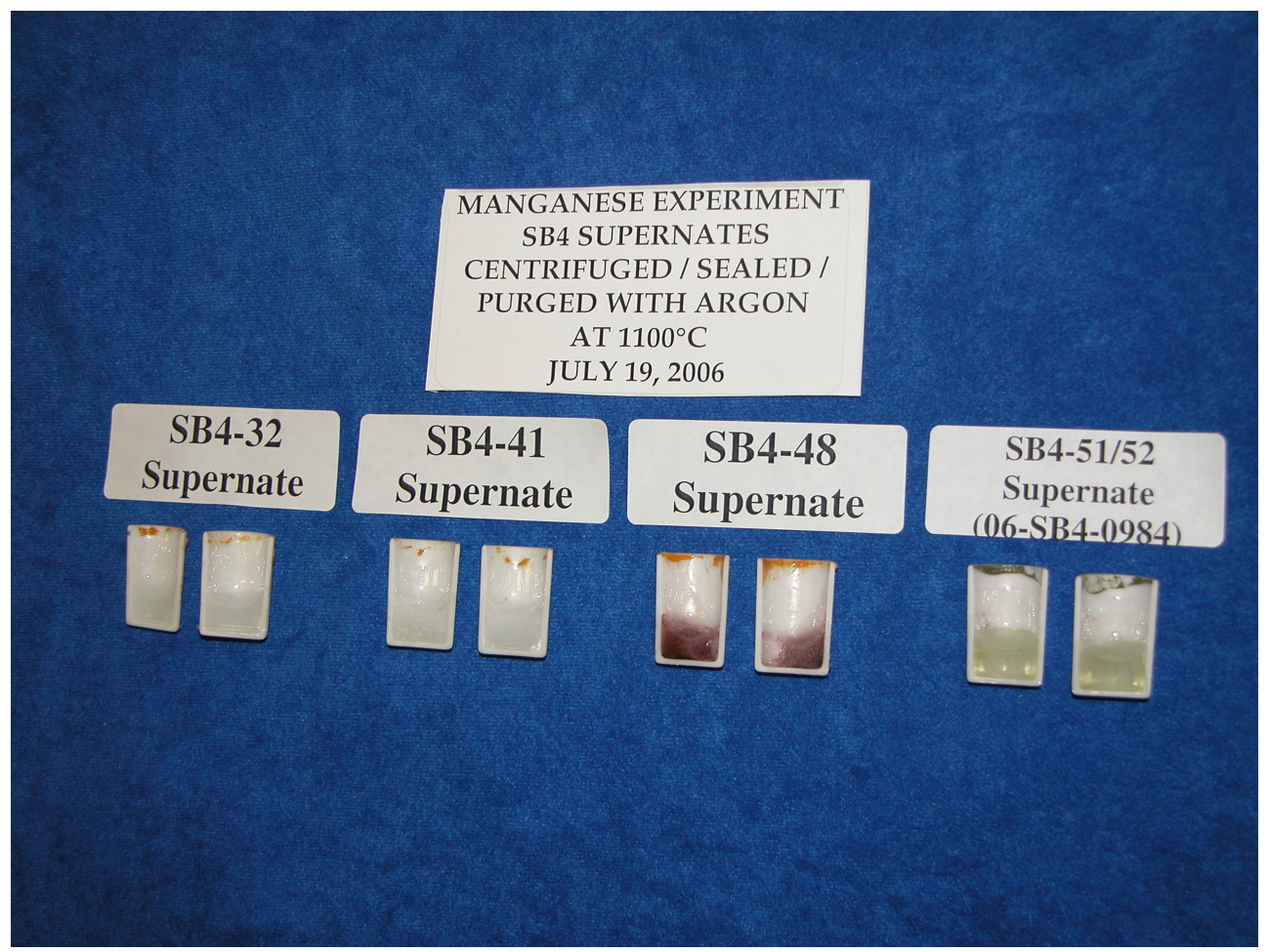

Figure 30. SB4 SRAT supernates tested in sealed crucibles with Frit 418.

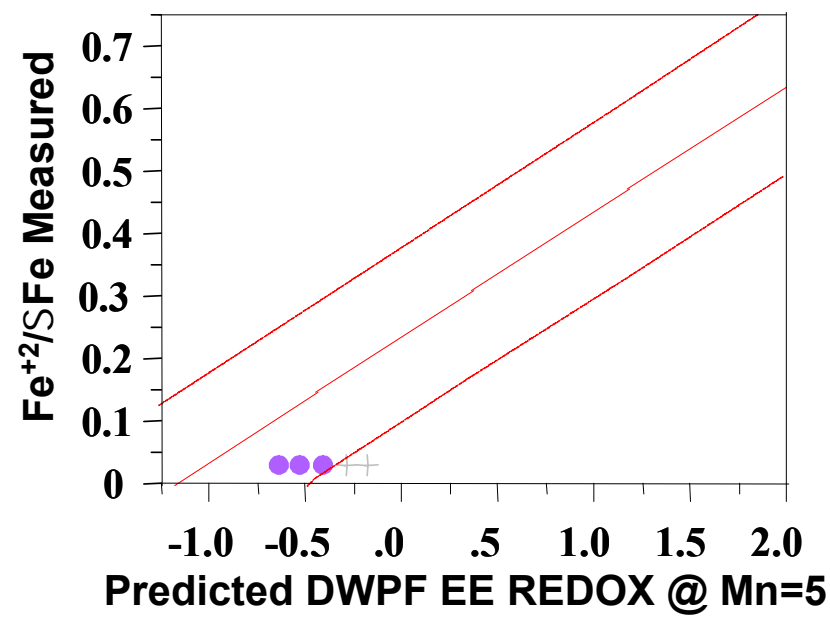

Figure 31. Solving Equation 11 at the minimum REDOX modeled, e.g. $\mathrm{Fe}^{+2} / \Sigma \mathrm{Fe}=0.03$, for the frit experiments. Gray crossed indicate glasses in Figure 27 that are clear and indicative of $\mathrm{Mn}^{+2}$ while purple solid circles indicate glasses that were purple in color indicative of $\mathrm{Mn}^{+3}$. 


\subsection{CONCLUSIONS}

DWPF should implement the refit Equation 11 with a factor of 5 Electron Equivalent transfers for manganese in order to avoid foaming in SB4 and other high manganese containing feeds:

$$
\frac{F e^{2+}}{\Sigma F e}=f\left[\left(2[F]+4[C]+4\left[\mathrm{O}_{\mathrm{T}}\right]-5[N]-5[M n]\right) \frac{45}{T}\right]=f[\xi]
$$

where $\quad f=$ indicates a function

$$
\begin{aligned}
{[\mathrm{F}] } & =\text { formate }(\mathrm{mol} / \mathrm{kg} \text { feed }) \\
{[\mathrm{C}] } & =\text { coal }(\text { carbon })(\mathrm{mol} / \mathrm{kg} \text { feed }) \\
{\left[\mathrm{O}_{\mathrm{T}}\right] } & =\text { oxalate } \\
{[\mathrm{N}] } & =\text { nitrat }(\text { soluble and insoluble })(\mathrm{mol} / \mathrm{kg} \text { feed }) \\
{[\mathrm{Mn}] } & =\text { manganese }(\mathrm{mol} / \mathrm{kg} \text { feed }) \\
\mathrm{T} & =\text { total solids }(\mathrm{wt} \%) \\
\xi & =\left(2[F]+4[C]+4\left[\mathrm{O}_{\mathrm{T}}\right]-5[N]-5[\mathrm{Mn}]\right) \frac{45}{T}
\end{aligned}
$$

and

$$
\frac{F e^{+2}}{\sum F e}=0.2358+0.1999 \xi
$$

This is necessary because the high nitrate in DWPF SB4 feeds is reoxidizing divalent manganese in the melter feeds during the denitration reactions in the cold cap. This process appears to be happening once but may be occurring multiple times in the cold cap reactions.

Since only 19 data points were available for modeling and many of the glasses were inhomogeneous, the five EE transfer for manganese should be further verified.

\subsection{RECOMMENDATIONS/PATH FORWARD}

The role of molten salts in the cold cap and the resulting effects on oxidation of manganese, chromium, uranium and other multivalent species should be studied further to understand this phenomena better. It is not known whether the molten salt effects only occur in alumina rich feeds which are of higher viscosity or in both alumina and iron rich feeds. Studies at higher manganese concentrations in iron rich feeds are needed since the Mn concentration in Purex HHW will be considerable (Table 1). Specifically, the relation of the manganese frit experiments to the SRAT supernates and \% soluble Mn in the feed needs to be examined in more detail. 


\subsection{ACKNOWLEDGEMENTS}

The authors would like to gratefully acknowledge the assistance of Alex Choi of the Savannah River National Laboratory for authoring Section 2.5. This paper was prepared in connection with work done under Contract No. DE-AC09-96SR18500 with the U.S. Department of Energy (DOE).

\subsection{REFERENCES}

1 M.J. Plodinec, "Effects of Surface Forces on Glass Melting - I," U.S. DOE Report DPST82-509, E.I. duPont deNemours \& Co., Savannah River Plant, Aiken, SC (April, 1982).

2 M.J. Plodinec, “Long-Term Waste Management Progress Report Small-Scale Electric Meter, II. Slag Formation,” U.S. DOE Report DPST-78-453, E.I. duPont deNemours \& Co., Savannah River Laboratory, Aiken, SC (August, 1978).

3 M.J. Plodinec, “Long-Term Waste Management Progress Report Small-Scale Electric Meter, IV. Effects of Feed Mixing and Segregation on Glass Melting," U.S. DOE Report DPST-79-227, E.I. duPont deNemours \& Co., Savannah River Laboratory, Aiken, SC (January, 1979).

4 M.J. Plodinec, "Foaming During Vitrification of SRP Waste," U.S. DOE Report DPST86-213, E.I. duPont deNemours \& Co., Savannah River Laboratory, Aiken, SC (January 10, 1986).

5 M.J. Plodinec, "Foaming and Dissolution of SRP Waste by Frit," U.S. DOE Report DPST-85-419, E.I. duPont deNemours \& Co., Savannah River Laboratory, Aiken, SC (April $8,1985)$.

6 M.J. Plodinec, "Factors Affecting the Iron Oxidation State and Foaming in SRP Waste Glass," Proceedings of the Symposium on High Temperature Materials Chemistry, D.D. Cubicciotti and D.L. Hildebrand (Eds.), The Electrochemical Society, Pennington, New Jersey, 201-211 (1982).

7 S.A. Cooper and P.S. Nicholson, "Influence of Glass Redox Conditions on the Corrosion of Fusion-Cast Chrome-Alumina Refractories," Ceramic Bulletin, 59[7], 715-717 (1980).

8 M. Cable, C.G. Rasul, and J. Savage, "Laboratory Investigation of Foaming and Reboil in Soda-Lime-Silica Melts," Glass Technology, 9[2], 25-31 (1968).

9 D.C. Iverson and D.F. Bickford, "Evaluation of Materials Performance in a Large-Scale Glass Melter After Two Years of Vitrifying Simulated SRP Defense Waste," Sci. Basis 
for Nuclear Waste Management, VIII, Materials Research Society, Pittsburgh, PA, 839-845 (1985).

10 W.G. Ramsey, C.M. Jantzen, and D.F. Bickford, "Redox Analyses of SRS Melter Feed Slurry: Interactions Between Nitrate, Formate and Phenol Based Dopants," Nuclear Waste Management IV, Ceramic Transactions, V.23, G.G. Wicks, D.F. Bickford and L.R. Bunnell (Eds.), American Ceramic Society, Westerville, OH, 259-266 (1991).

11 T.B. Calloway, C.M. Jantzen, L.M. Medich, and N.R. Spennato, "Analysis of the DWPF Glass Pouring System Using Neural Networks,” Waste Management '98 (1998).

12 K.G. Brown, C.M. Jantzen, and J.B. Pickett, "The Effects of Formate and Nitrate on

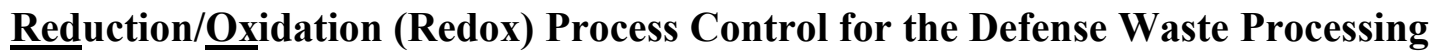
Facility (DWPF), U.S. DOE Report WSRC-RP-97-34, Rev. 1 (June 30, 1998).

13 M.J. Singleton, "Comparison of Sludge Batches 1A, 1B, and 2," U.S. DOE Report HLWPRE-200209950.

14 C.W. Hsu, "Defense Waste Processing Facility Nitric Acid Requirement for Treating Sludge," U.S. DOE Report WSRC-RP-92-1056, Savannah River Technology Center, Westinghouse Savannah River Co., Aiken, SC (September, 1992).

15 C.M. Jantzen, J.R. Zamecnik, D.C. Koopman, C.C. Herman, and J.B. Pickett, "Electron Equivalents Model for Controlling REDuction/OXidation (REDOX) Equilibrium During High Level Waste (HLW) Vitrification," U.S. DOE Report WSRC-TR-200300126, Rev.0 (May 9, 2003).

16 C.M. Jantzen, D.C. Koopman, C.C. Herman, J.B. Pickett, and J.R. Zamecnik, "Electron Equivalents REDOX Model for High Level Waste Vitrification," Environmental Issues and Waste Management Technologies IX, J.D. Vienna and D.R. Spearing (Eds), Ceramic Transactions 155, 79-91 (2004).

17 M.E. Smith, T.M. Jones, D.H. Miller, and M.E. Stone, "SB4 SMRF Runs with Frits 418 and 320", U.S. DOE Report WSRC-TR-2005-00569, Savannah River Site, Aiken, SC (2005).

18 J.M. Gillam, "Aluminum in Waste Tank Sludge: History and Status," U.S. DOE Memorandum CBU-PIT-2006-00068, Rev. 0, Savannah River Site, Aiken, SC (July 11, 2006).

19 National Technical Information Service, "Final Environmental Impact Statement Waste Management Operations," Savannah River, Plan, Aiken, SC, ERDA-1537 (September, 1977).

20 F.D. Lorey, “Reboil Phenomena in Glass,” Am. Ceram. Soc. Bull., 45[11], 1012-1013 (1966). 
21 D.S. Goldman, "Melt Foaming, Foam Stability and Redox in Nuclear Waste Vitrification," J. Non-Cryst. Solids, 84, 292-298 (1986).

22 H.D. Schreiber and A.L. Hockman, "Redox Chemistry in Candidate Glasses for Nuclear Waste Immobilization," Journal of the American Ceramic Society, Vol. 70, No. 8, pp. 591594 (1987).

23 D.S. Goldman and D.W. Brite, "Redox Characterization of Simulated Nuclear Waste Glass," J. Am. Ceram. Soc., 69 [5], pp. 411-413, (1986).

24 V. Jain, "Redox Forecasting in the West Valley Vitrification System," Ceramic Transactions, Vol. 29, Advances in the Fusion and Processing of Glass, Eds., A. K. Varsheya, D. F. Bickford, and P. P. Bihuniak, pp. 523-533, (1983).

25 P.D. Soper, "Analysis of Gas in Foam from LSFM Run 6," U.S. DOE Report DPST-83259, E.I. duPont deNemours \& Co., Aiken, South Carolina (January, 1983).

26 M.E. Stone and D.P. Lambert, "DWPF Macrobatch 2 Melt Rate Tests," U.S. DOE Report WSRC-TR-2000-00395, Westinghouse Savannah River Company, Aiken, SC (2000).

27 A.S. Choi, “Maximum Total Organic Carbon Limit for DWPF Melter Feed," U.S. DOE Report WSRC-TR-95-0119, Rev. 0, Westinghouse Savannah River Company, Aiken, SC (March 13, 1995).

28 D.F. Bickford and A.S. Choi, "Control of High Level Radioactive Waste-Glass MelterPart 5: Modeling of Complex Redox Effects," Proceedings of the Fifth International Symposium on Ceramics in Nuclear and Hazardous Waste Management (Eds. G.G. Wicks, D.F. Bickford, and L.R. Bunnell, Ceramic Transactions Vol. 23, American Ceramic Society, Westerville, OH, 267-279 (1991).

29 M.J. Plodinec, "Vitrification Chemistry and Nuclear Waste," J. Non-Cryst. Solids, 84, 206-214 (1986).

30 J.F. Wosinski and J.R. Kearney, "Methods of Determining Probable Sources of Gaseous Inclusions in Glass," Am. Ceram. Soc. Bull., 45[11], 1001-1002 (1966).

31 B.A. Hamm, R.E. Eibling, M.A. Ebra, T. Motyka, and H.D. Martin, "High-Level Insoluble Waste Preparation for Vitrification," Sci. Basis for Nuclear Waste Management, VIII, C. M. Jantzen, et al. (Eds.), Materials Research Society, Pittsburgh, PA 793-799 (1985).

32 C.W. Hsu, "Formic Acid Requirement in the DWPF Chemical Processing Cell," U.S. DOE Report WSRC-RP-90-0554, Westinghouse Savannah River Company, Aiken, SC (July 1990). 
33 H.D. Schreiber, C.W. Schreiber, M.W. Riethmiller and J.S. Downey, "The Effect of Temperature on the Redox Constraints for the Processing of High-level Nuclear Waste into a Glass Waste Form," Scientific Basis for Nuclear Waste Management, XIII, V.M. Oversby and P.W. Brown (Eds.), Materials Research Society, Pittsburgh, PA, 419-426 (1990).

34 H.D. Schreiber, P.G. Leonhard, R.G. Nofsinger, M.W. Henning, C.W. Schreiber, and S.J. Kozak, "Oxidation-Reduction Chemistry of Non-Metals in a Reference Borosilicate Melt," Advances in the Fusion of Glass, D.F. Bickford, W.E. Horsfall, F.E. Wooley, E.N. Boulos, J.N. Lingscheit, F. Harding, F. Olix, W.C. LaCourse, and L.D. Pye (Eds.), Am. Ceram. Soc., Westerville, OH, 29.1-29.14 (1988).

35 H.D. Schreiber, F.A. Settle, Jr., P.L. Jamison, J.P. Eckenrode, and G.W. Headley, "Ruthenium in Glass Forming Borosilicate Melts," J. Less Common Metals, 115, 145-154 (1986).

36 C.M. Jantzen, J.B. Pickett, K.G. Brown, T.B. Edwards, and D.C. Beam, "Process/Product Models for the Defense Waste Processing Facility (DWPF): Part I. Predicting Glass Durability from Composition Using a Thermodynamic Hydration Energy Reaction MOdel (THERMO)," US DOE Report WSRC-TR-93-0672, 464p. (September, 1995).

37 C.M. Jantzen and M.J. Plodinec, "Composition and Redox Control of Waste Glasses: Recommendation for Process Control Limit," U.S. DOE Report DPST-86-773, E.I. duPont deNemours \& Co., Savannah River Laboratory, Aiken, SC (November 19, 1986).

38 M.E. Smith, D.H. Miller, and T.H. Lorier, "The Impact of Feed Preparation Acid Stoichiometry and REDOX on Melt Rate for the SB3-418 Feed System," U.S. DOE Report WSRC-TR-2004-00350, Westinghouse Savannah River Company, Aiken, SC (2004).

39 C.G. Rasul and M. Cable, "Spontaneous Bubble Formation in Silicate Melts at High Temperatures," J. Am. Ceram. Soc., 49[10], 568-571 (1966).

40 A. Muan and E.F. Osborn, "Phase Equilibria Among Oxides in Steelmaking," AddisonWesley Publishing Company, Inc., Reading, MA, 236pp. (1965).

41 C.M. Jantzen, "Uranium Surrogate for DWPF Melt Rate, Foaming, Oxygen Generation, and REDOX Testing," SRT-GPD-2003-00155 (January 25, 2004).

42 D.F. Bickford and A.S. Choi, "Control of High Level Radioactive Waste-Glass MelterPart 5: Modeling of Complex Redox Effects," Proceedings of the Fifth International Symposium on Ceramics in Nuclear and Hazardous Waste Management (Eds. G.G. Wicks, D.F. Bickford, and L.R. Bunnell, Ceramic Transactions Vol. 23, American Ceramic Society, Westerville, OH, 267-279 (1991).

43 A.S. Choi, "Validation of DWPF Melter Off-Gas Combustion Model," U.S. DOE Report WSRC-TR-2000-00100, Westinghouse Savannah River Co., Aiken, SC (June 23, 2000). 
44 A.S. Choi, "Prediction of Melter Off-Gas Explosiveness," U.S. DOE Report WSRC-TR90-00346, Westinghouse Savannah River Co., Aiken, SC (January 22, 1992).

45 D.C. Koopman, C.C. Herman, N.E. Bibler, "Sludge Batch 3 Preliminary Acid

Requirements Studies with Tank 8 Simulant," U.S. DOE Report WSRC-TR-2003-00041, Westinghouse Savannah River Co., Aiken, SC (January 31, 2003).

46 B.M. Rapko and G.J. Lumetta, "Status Report on Phase Identification in Hanford Tank Sludges," U.S. DOE Report PNNL-13394, Pacific Northwest National Laboratory, Richland, WA (December 2000).

47 A.F. Weisman/Scale Melter Team, "Run Summaries from SGM-1, SGM-3, and SGM-4," U.S. DOE Report DPST-86-862, E.I. duPont deNemours \& Co., Savannah River Laboratory, Aiken, SC (1986).

48 K.R. Crow, A.F. Weisman, P.D. Guidotti, A.M. Wehner, G.A. Griffin, J.M. Micallef, J.M. O'Rourke and M. Yoshioka, "Summary of Campaigns SGM-4 and SGM-5 of the DWPF Scale Glass Melter," U.S. DOE Report DPST-87-247, E.I. duPont deNemours \& Co., Savannah River Laboratory, Aiken, SC (1987).

49 P.D. Guidotti, K.R. Crow, A.F. Weisman, M.R. Baron, A.M. Wehner, J.A. Voogd, M.E. Smith, S.L. Goudelock, G.A. Griffin, J.A. Shuford and J.M. O’Rourke, "Summary of Campaigns SGM-6 and SGM-7 of the DWPF Scale Glass Melter," U.S. DOE Report DPST-87-532, E.I. duPont deNemours \& Co., Savannah River Laboratory, Aiken, SC (1987).

50 R.E. Edwards, S.L. Goudelock, M.E. Smith, M.R. Baron, P.D. Guidotti, A.M. Wehner and J. A. Shuford, "Summary of Campaign SGM-8 of the DWPF Scale Glass Melter," U.S. DOE Report DPST-87-850, E.I. duPont deNemours \& Co., Savannah River Laboratory, Aiken, SC (1987).

51 A.S. Choi, M.E. Smith, K.R. Crow, M.R. Baron, G.F. Rabon, S.L. Goudelock and A.M. Wehner, "Summary of Campaigns SGM-9 and SGM-10 of the DWPF Scale Glass Melter," U.S. DOE Report DPST-88-626, E.I. duPont deNemours \& Co., Savannah River Laboratory, Aiken, SC (1988).

52 D.F. Bickford and C.M. Jantzen, "Inhibitor Limits for Washed Precipitate Based on Glass Quality and Solubility Limits," U.S. DOE Report DPST-86-546, E.I. duPont deNemours \& Co., Savannah River Laboratory, Aiken, SC (1986).

53 J.R. Zamecnik, N.D. Hutson, M.E. Smith, D.H. Miller and J.A. Ritter, "Integrated DWPF Melter System (IDMS) Campaign Report - DWPF Cold Run Demonstrations," U.S. DOE Report WSRC-RP-93-593, Rev. 0, Westinghouse Savannah River Company, Aiken, SC (April 21, 1993). 
54 N.D. Hutson, "An Evaluation of Foaming Potential in the IDMS Melter," U.S. DOE Report WSRC-TR-92-0491, Westinghouse Savannah River Co., Savannah River Laboratory, Aiken, SC (October 1992).

55 D.F. Bickford, C.J. Coleman, C-L.W. Hsu, and R.E. Eibling, "Noble Metal Catalyzed Formic Acid Decomposition, and Formic Acid Denitration," Nuclear Waste Management IV, Ceramic Transactions, V.23, G.G. Wicks, D.F. Bickford and L.R. Bunnell (Eds.), American Ceramic Society, Westerville, OH, 283-294 (1991).

56 M.E. Smith, N.D. Hutson, D.H. Miller, J. Morrison, H. Shah, J.A. Shuford, J. Glasscock, F.H. Wurvinger, and J.R. Zamecnik, "Checkout and Startup of the Integrated DWPF Melter System," U.S. DOE Report WSRC-RP-89-321, Westinghouse Savannah River Co., Savannah River Laboratory, Aiken, SC (November, 1989).

57 J.A. Ritter, N.D. Hutson, M.E. Smith, M.K. Andrews, D.H. Miller, and J.R. Zamecnik, “Integrated DWPF Melter System Campaign Report Coupled Feed Operation," U.S. DOE Report WSRC-TR-90-131, Westinghouse Savannah River Company, Aiken, SC (1990)

58 N.D. Hutson, J.R. Zamecnik, M.E. Smith, D.H. Miller and J.A. Ritter, "Integrated DWPF Melter System (IDMS) Campaign Report: Mercury Operation," U.S. DOE Report WSRC-TR-91-363, Westinghouse Savannah River Company, Aiken, SC (May 22, 1991).

59 N.D. Hutson, J.R. Zamecnik, M.E. Smith, D.H. Miller and J.A. Ritter, "Integrated DWPF Melter System (IDMS) Campaign Report: The First Two Noble Metals Operations," U.S. DOE Report WSRC-TR-91-400, Westinghouse Savannah River Company, Aiken, SC (June, 1991).

60 N.D. Hutson, "Integrated DWPF Melter System (IDMS) Campaign Report: Hanford Waste Vitrification Plan (HWVP) Process Demonstration," U.S. DOE Report, WSRCTR-92-403, Rev. 1, Westinghouse Savannah River Company, Aiken, SC (June 11, 1993).

61 J.M. Perez and R.W. Nakaoka, "Vitrification Testing of Simulated High-Level Radioactive Waste from Hanford," Waste Management '86, R.G. Post (Ed.), Proceedings of the Symposium in Waste Management at Tucson, AZ, March 2-6, 1986, 495-505 (1986).

62 S.A. Degterov and A.D. Pelton, “Thermodynamic Calculation of Glass/Slag/ Refractory Equilibria in Coal Gassification," Corrosion of Materials by Molten Glass, G.A. Pecoraro, J.C. Marra, and J.T. Wenzel (Eds), Ceramic Transactions, V. 78, Am. Ceram. Soc., Westerville, OH, 91-103 (1996).

63 D.S. Goldman, D.W. Brite, and W.C. Richey, "Investigation of Foaming in Liquid Fed Melting of Simulated Nuclear Waste Glass," J. Am. Ceram. Soc., 69[5], 413-417 (1986).

64 P.A. Smith, J.D. Vienna, and P. Hrma, "The Effects of Melting Reactions On Laboratory Scale Waste Vitrification,” J. Mater. Res., 10[8], 2137-2149 (1995). 
65 M.M. Chotin, R.A. Bonniaud, A.F. Jouan, and G.E. Rabot, "Operational Experience of the First Industrial HLW Vitrification Plant," Ceramics in Nuclear Waste Management, U.S. DOE Report CONF-790420, U.S. Department of Energy, National Technical Information Service, Springfield, VA 73-81 (1979).

66 K.G. Brown, C.M. Jantzen, and J.B. Pickett, "The Effects of Formate and Nitrate on Reduction/Oxidation (REDOX) Process Control for the Defense Waste Processing Facility (DWPF)," U.S. DOE Report WSRC-RP-97-34, Westinghouse Savannah River Company, Aiken, SC (February, 1997).

67 N.D. Hutson and J.R. Zamecnik, "Integrated DWPF Melter System (IDMS) Campaign Report: IDMS Purex-6 (PX6) Operation,” U.S. DOE Report WSRC-TR-94-0556, Rev. 0, Westinghouse Savannah River Company, Aiken, SC (November, 1994).

68 P.D. Soper, "Determination of Causes of Foaming in the Small Cylindrical Melter" U.S. DOE Report DPST-83-260, E.I. duPont deNemours \& Co., Aiken, South Carolina (January, 1983).

69 M.J. Plodinec, "Factors Affecting Iron Oxidation State and Foaming in SRP Waste Glass," U.S. DOE Report DPST-80-685, E.I. duPont deNemours \& Co., Aiken, South Carolina (December, 1980).

70 D.P. Lambert, "Task Technical \& QA Plan: Sludge Batch 4 Simulant Flowsheet Studies with MCU and ARP," U.S. DOE Report WSRC-RP-2004-00881, Rev. 1," Savannah River Site, Aiken SC (2006).

71 E.W. Baumann, "Colorimetric Determination of Iron(II) and Iron(III) in Glass," Analyst, 117, 913-916 (1992).

72 M.A. Baich, et al, "Sludge Batch Four Initial Simulant Flowsheet Studies: Phase I Results”, U.S. DOE Report WSRC-TR-2005-00194, Savannah River Site, Aiken, SC 29803 (2005).

73 C.C. Herman, et al, "Sludge Batch 4 without Tank 4 Simulant Flowsheet Studies: Phase I SRAT Results", U.S. DOE Report WSRC-TR-2005-00493, Savannah River Site, Aiken, SC 29803 (2005).

74 M.E. Stone, "Feed Preparation for SB4 Slurry-Fed Melt Rate Furnace Tests" U.S. DOE Report SRNL-ITS-2005-00298, Savannah River Site, Aiken, SC 29803 (2005).

75 M.E. Stone, "FY06 Feed Preparation for Melt Rate Testing," U.S. DOE Report WSRCSTI-2006-00007, Savannah River Site, Aiken, SC 29803 (2006).

76 M.E. Stone, "Run Plan for REDOX Determinations of SB4 SRAT Products, " U.S. DOE Report SRNL-PSE-2006-00023, Savannah River Site, Aiken, SC (2006) 
77 M.E. Stone, "Run Plan for Alternative Reductant REDOX Determinations," U.S. DOE Report SRNL-PSE-2006-00045, Savannah River Site, Aiken, SC (2006).

78 M.E. Stone and D.R. Best, "Sludge Batch 4 Simulant Flowsheet Studies: Phase II Results," U.S. DOE Report WSRC-STI-2006-00109 (2006).

79 H.B. Shah, "Estimate of Sludge Batch 4 Calcine Composition Additional Cases for Final Recommendation," CBU-PIT-2006-00011, Rev. 0, Washington Savannah River Company, Aiken, South Carolina (2006).

80 C.M. Jantzen and D.F. Bickford, "Leaching of Devitrified Glass Containing Simulated SRP Nuclear Waste,' Sci. Basis for Nuclear Waste Management, VIII, C.M. Jantzen, J.A. Stone and R.C. Ewing (eds.), Materials Research Society, Pittsburgh, PA 135-146 (1985).

81 D.K. Peeler and T.B. Edwards, "Model Based Assessments of the Final SB4 Projected Compositions Leading to the Frit Recommendation," U.S. DOE Report WSRC-TR-200600269 (July 2006).

82 H. Li, Y. Su, J.D. Vienna, and P. Hrma, "Raman Spectroscopic Study - Effects of $\mathbf{B}_{2} \mathbf{O}_{3}$, $\mathrm{Na}_{2} \mathrm{O}$, and $\mathrm{SiO}_{2}$ on Nepheline (NaAlSiO$)_{4}$ ) Crystallization in Simulated High Level Waste Glasses," Environmental Issues and Waste Management Technologies, V, G.T. Chandler and X. Feng (Eds.), Ceramic Trans. 107, 469-477 (2000).

83 H.S. Waff, "The Structural Role of Ferric Iron in Silicate Melts," Canadian Mineralogist, 15, 198-199 (1977).

84 W.D. Bancroft and R.L. Nugent, “The Manganese Equilibrium in Glasses,” J. Phys. Chem. 33, 481-497 (1929).

85 H.D. Schreiber, P.G. Leonhard, R.G. Nofsinger, M.W. Henning, C.W. Schreiber, and S.J. Kozak, "Oxidation-Reduction Chemistry of NonMetals in a Reference Borosilicate Melt," Advances in the Fusion of Glass, D.F. Bickford, W.E. Horsfall, F.E. Wooley, E.N. Boulos, J.N. Lingscheit, F. Harding, F. Olix, W.C. LaCourse, and L.D. Pye (Eds.), Am. Ceram. Soc., Westerville, OH, 29.1-19.14 (1988).

86 C.M. Jantzen, A.D. Cozzi, and N.E. Bibler, "Characterization of Defense Waste Processing Facility (DWPF) Glass and Deposit Samples from Melter \#2," U.S. DOE Report WSRC-TR-2003-00504 (March 1, 2004).

87 M.E. Smith, M.E. Stone, T.M. Jones, D.H. Miller, P.R. Burket and D.M. Immel, "Sludge Batch 4 Melt Rate Furnace and Slurry-Fed Melt Rate Furnace Tests with Frits 418, 425, and 503," U.S. DOE Report WSRC-STI-2006-00015 (June 2006).

88 C.H. Baes and R.E. Mesmer, "The Hydrolysis of Cations," John Wiley \& Sons, New York, 489 pp., (1976) 
89 D.T. Herman, M.E. Stone, M.R. Poirier, and J.G. Wheeler, "Preparation of Sludge Batch 4 Simulant," U.S. DOE Report RNL-WPT-00130 (October 2005).

90 EPA, "Potassium Permanganate," Chapter 5 in Alternative Disinfectants and Oxidants, EPA Guidance Manual (April 1999).

91 J. Kleinberg, W.J. Argersinger, Jr., and Griswold, E., "Inorganic Chemistry," D.C. Heath and Company, Boston, MA, 680pp. (1960).

92 W.A. Weyl, “Coloured Glasses,” Society of Glass Technology, Sheffield, England, 541pp. (1951).

93 M.B. Volf, “Chemical Approach to Glass,” Science \& Technology, V.7, Elsevier, Amsterdam, Holland, 594pp. (1984).

94 W. D. Bancroft and R.L. Nugent, "The Manganese Equilibria in Glasses," Journal of Physical Chemistry, 33, 481-497 (1929).

95 J.L. Ryan, "REDOX Reactions and Foaming in Nuclear Waste Glass Melting," PNL10510 (August 1995).

96 R.B. Temple and G.W. Thickett, "The Influence of Cations on the Formation of High Oxidation State Compounds of Manganese in Molten Salts," Aust. J. Chem., 26, 2051-3 (1973). 
Distribution:

R.E. Edwards, 773-A

D.A. Crowley, 999-W

C.C. Herman, 999-W

T.B. Calloway, 999-W

D.B. Burns, 785-5A

N.E. Bibler, 773-A

J. R. Harbour, 773-42A

D.C. Koopman, 999-W

D.K. Peeler, 999-W

M.E. Smith, 999-W

M.E. Stone, 999-W

A.S. Choi, 773-42A

G.G. Wicks, 773-A

J. M. Pareizs, 773-A

S.L. Marra, 773-A

C.J. Bannochie, 773-42A

B.R. Pickenheim, 999-W

D.P. Lambert, 999-W

J. E. Occhipinti, 704-S

S.D. Burke, 704-S

R.T. McNew, 704-27S

J. F. Iaukea, 704-30S

J. W. Ray, 704-S

B. A. Davis, 704-27S

J.L. Dunning, 766-H

B.A. Hamm, 766-H

H.H. Elder, 766-H

H.B. Shah, 766-H

J.M. Gillam, 766-H

D.C. Iverson, 704-30S 